\title{
DESENVOLVIMENTO DE BROMÉLIAS EM AMBIENTES PROTEGIDOS COM DIFERENTES ALTURAS E NÍVEIS DE SOMBREAMENTO
}

\section{PAULETTI KARLLIEN ROCHA}

\author{
Dissertação apresentada à Escola Superior de \\ Agricultura "Luiz de Queiroz”, Universidade de São \\ Paulo, para obtenção do título de Mestre em \\ Agronomia, Área de Concentração: Irrigação e \\ Drenagem.
}

\author{
PIRACICABA \\ Estado de São Paulo - Brasil \\ Abril-2002
}




\section{DESENVOLVIMENTO DE BROMÉLIAS EM AMBIENTES PROTEGIDOS COM DIFERENTES ALTURAS E NÍVEIS DE SOMBREAMENTO}

\section{PAULETTI KARLLIEN ROCHA}

Engenheira Agrônoma

Orientador: Prof. Dr. IRAN JOSÉ OLIVEIRA DA SILVA

Dissertação apresentada à Escola Superior de

Agricultura "Luiz de Queiroz", Universidade de São

Paulo, para obtenção do título de Mestre em

Agronomia, Área de Concentração: Irrigação e Drenagem.

PIR A C ICABA

Estado de São Paulo - Brasil

Abril-2002 
Dados Internacionais de Catalogação na Publicação (CIP)

DIVISÃO DE BIBLIOTECA E DOCUMENTAÇÃO - ESALQ/USP

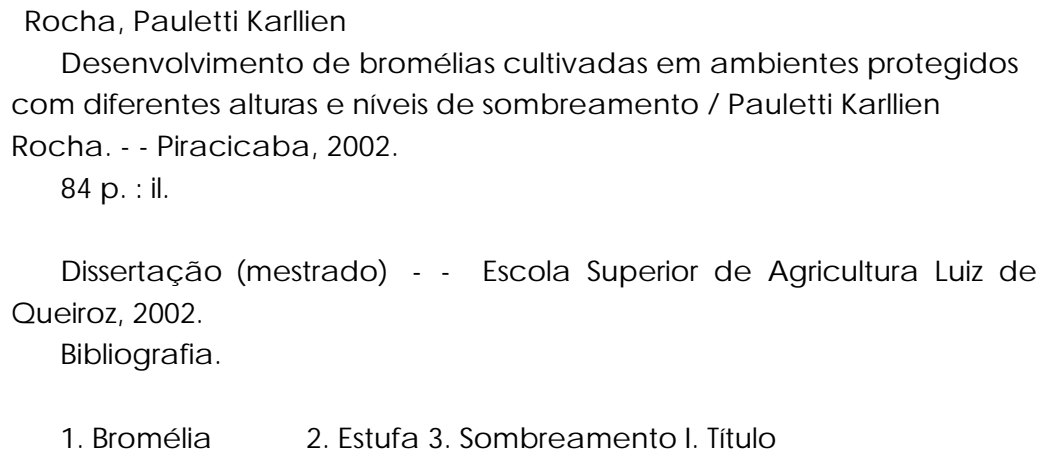

CDD 635.93422 
Aos meus pais, José Francisco e Maria Helena Rocha, À Joaquina, minha amada avó, pelo amor e pelo incentivo, Ofereço e Dedico. 


\section{AGRADECIMENTOS}

A Deus pela minha vida;

À Escola Superior de Agricultura "Luiz de Queiroz" - ESALQ/USP e ao Núcleo de Pesquisa em Ambiência (NUPEA), através do Departamento de Engenharia Rural, pela oportunidade de aperfeiçoamento;

Ao professor Dr. Iran José Oliveira da Silva, pela orientação durante todo o período de elaboração e de execução deste trabalho;

A todos os professores do Departamento de Engenharia Rural, ESALQ/USP, em especial à professora Dr. Daniella Jorge de Moura, aos professores do Departamento de Ciências Exatas Dr. Paulo César Sentelhas e

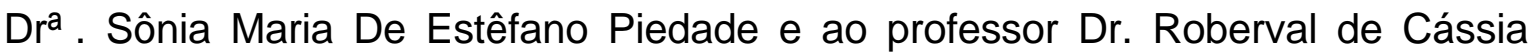
Salvador Ribeiro do Departamento de Produção Vegetal, pela colaboração e pelas sugestões;

Aos colegas e amigos do Núcleo de Pesquisa em Ambiência, especialmente æ̀̀ amigas Edilaine Regina Pereira e Soraia Vanessa Matarrazzo, aos amigos José Luís Martins e Luiz Carlos Roma Júnior e aos colegas do curso de pós-graduação em Irrigação e Drenagem;

Aos funcionários do Departamento de Engenharia Rural da ESALQ, pela amizade e pelos serviços prestados;

À Fundação de Amparo à Pesquisa do Estado de São Paulo - FAPESP -, pela concessão da bolsa de estudos;

Ao senhor Rolf E. Zornig, proprietário da Empresa Bromélias Rio, pela doação das mudas de bromélias; 
A todos aqueles que contribuíram de qualquer forma e em qualquer etapa, para a realização deste trabalho. 


\section{SUMÁRIO}

Página

LISTA DE FIGURAS ......................................................................... viii

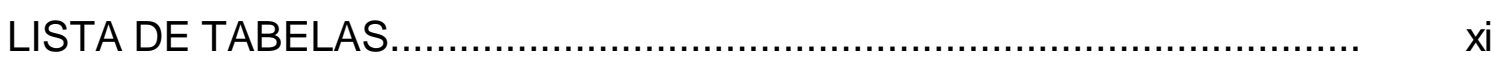

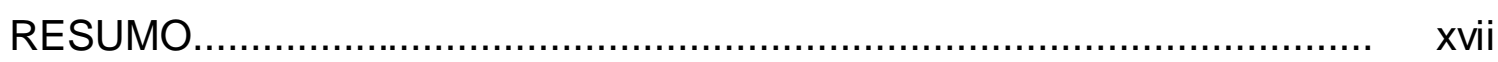

SUMMARY

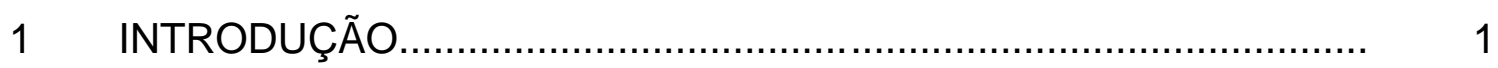

2 REVISÃO DE LITERATURA......................................................... 4

$2.1 \quad$ Bromélias........................................................................... 4

2.1.1 Origem e História..................................................................... 4

2.1.2 Morfologia ........................................................................ 7

2.1.3 Classificação taxonômica.......................................................... 8

2.1.4 Produção comercial de bromélias................................................ 11

2.2 Cultivo em ambiente protegido.................................................... 12

2.3 Ambiência em cultivo protegido...................................................... 14

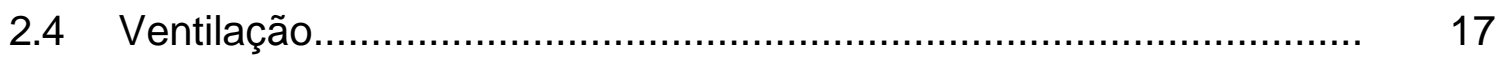

2.5 Sistema de resfriamento adiabático evaporativo por nebulização...... 19

2.6 Luminosidade..................................................................... 20

2.7 Microclima no interior dos ambientes protegidos.............................. 23

2.7.1 Radiação solar...................................................................... 23

2.7.2 Temperatura do ar............................................................... 24

2.7.3 Umidade relativa do ar.......................................................... 25

2.7.4 Temperatura de globo negro e carga térmica radiante.................... 27

3 MATERIAL E MÉTODOS....................................................... 28 
3.1 Localização do experimento .................................................... 28

3.2 Instalação do experimento........................................................... 28

3.2.1 Ambientes protegidos............................................................. 30

3.2.2 Bancadas de cultivo e sistema de sombreamento......................... 30

3.2.3 Material vegetal................................................................... 33

3.2.4 Recipientes para o cultivo...................................................... 34

3.2.5 Substrato .................................................................. 35

3.2.6 Espaçamento entre os vasos.................................................. 35

3.2.7 Adubações....................................................................... 36

3.2.8 Sistema de irrigação e nebulização............................................... 36

3.2.9 Controle de pragas e de doenças................................................. 39

3.3 Coleta de dados................................................................. 39

3.3.1 Dados micrometeorológicos......................................................... 39

3.3.2 Dados da planta.......................................................................... 43

3.4 Delineamento estatístico............................................................ 46

4 RESULTADOS E DISCUSSÃO.................................................... 49

4.1 Características do ambiente...................................................... 49

4.1.1 Temperatura do ar................................................................ 49

4.1.2 Umidade relativa do ar............................................................ 52

4.1.3 Radiação solar global............................................................ 56

4.1.4 Temperatura de globo negro e carga térmica radiante................... 58

4.1.5 Intensidade luminosa.................................................................. 61

4.2 Características do desenvolvimento da planta................................... 64

4.2.1 Aechmea fasciata 65

4.2.2 Guzmania lingulata................................................................ 71

4.3 Considerações finais $\quad 80$

4.4 Sugestões para novas pesquisas 81

5 CONCLUSÕES........................................................................ 82

REFERÊNCIAS BIBLIOGRÁFICAS....................................................... 83 


\section{LISTA DE FIGURAS}

Página

1 Fotos das duas espécies de bromélias adultas utilizadas no experimento, (a) A. fasciata e (b) G. lingulata....................................

2 Organograma referente ao ambiente protegido com altura de $3,5 \mathrm{~m}$....

3 Organograma referente ao ambiente protegido com altura de $3,0 \mathrm{~m} \ldots .$.

4 Vista dos ambientes protegidos (1 e 2), com 3,5 e 3,0m de altura, respectivamente, utilizados na condução do experimento, no NUPEA/ESALQ/USP, em Piracicaba, SP

5 Desenho esquemático da distribuição dos tratamentos, no interior dos ambientes protegidos com diferentes alturas..............................

6 Vista de uma das bancadas de cultivo, com a estrutura de sombreamento com tela de $40 \%$, fixada acima da sua superfície........

7 Telas com diferentes percentagens de sombreamento, utilizadas no experimento. 
8 Mudas de A. fasciata (a) e G. lingulata (b), utilizadas na condução do experimento

9 Vasos de 15 e $10 \mathrm{~cm}$ de diâmetro na parte superior, utilizados no experimento para o acondicionamento das mudas de bromélias..........

10 Vista de uma das bancadas de cultivo, com as mudas de G. lingulata transplantadas para os vasos no 10 , localizada no interior do ambiente protegido com altura de $3,5 \mathrm{~m}$.

11 Bomba KSB, com sistema de filtragem de água (a) e painel de acionamento do sistema de irrigação e de nebulização (b), situados na área experimental do NUPEA/ESALQ/USP, em Piracicaba, $\mathrm{SP}$

12 Microaspersor sob a tela de sombreamento de $18 \%$, que promoveu a irrigação das plantas sobre a bancada de cultivo

13 Vista do ambiente protegido com altura de $3,5 \mathrm{~m}$, com o sistema de nebulização acionado.

14 Sistemas automáticos de aquisição de dados, usados na coleta de dados tanto no interior dos ambientes protegidos (a), quanto no exterior (b)

15 Termômetro de globo negro (a) e luxímetro digital (b), utilizados para a coleta de dados de temperatura de globo negro $\left({ }^{\circ} \mathrm{C}\right)$ e de intensidade luminosa (lux).............................................................. 
16 Desenho esquemático, mostrando o critério adotado para a medida do maior diâmetro (MD) e da folha com maior largura (L), da espécie

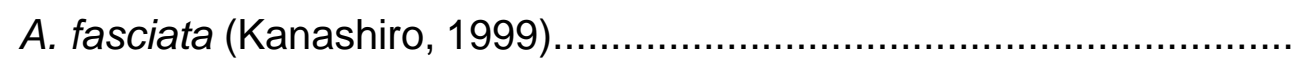

17 Plantas da espécie G. lingulata com queimaduras nas folhas e ao lado vaso com a planta já morta, foto referente aso 380 dias de

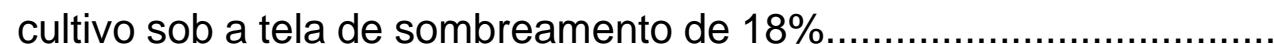

18 Plantas de $A$. fasciata submetidas a diferentes níveis de sombreamento, ao longo do ciclo de cultivo de 380 dias....................

19 Plantas de G. lingulata submetidas a diferentes níveis de sombreamento, ao longo do ciclo de cultivo de 380 dias. 


\section{LISTA DE TABELAS}

Página

1 Distribuição da produção de flores no Brasil, número de produtores, área cultivada e vendas por região/estado - 1999

2 Médias referentes às medidas realizadas nas mudas de bromélias, no início do experimento.................................................................... 33

3 Delineamento inteiramente ao acaso, para as variáveis

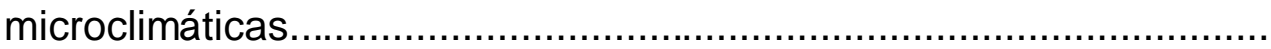

4 Delineamento inteiramente casualizado, com parcela subdividida com fatorial na parcela, para as variáveis da parte vegetativa das bromélias

5 Blocos ao acaso no esquema fatorial $2 \times 4$, com repetição dentro de blocos, para a variável intensidade luminosa

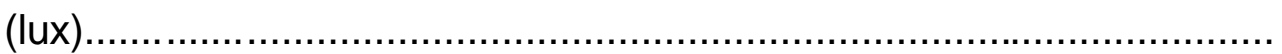

6 Resultado do teste de Tukey para as médias horárias de temperatura do ar $\left({ }^{\circ} \mathrm{C}\right)$, em função dos diferentes ambientes analisados no intervalo das 8 æ̀ 18h, ESALQ/USP, em Piracicaba, SP. 
7 Resultados do Teste de Tukey, para as médias horárias de temperatura do ar $\left({ }^{\circ} \mathrm{C}\right)$, sob as telas de sombreamento com diferentes percentagens no ambiente com altura de 3,5m, no intervalo das 8 à 18h, ESALQ/USP, em Piracicaba, $\mathrm{SP}$

8 Resultados do Teste de Tukey, para as médias horárias de temperatura do ar $\left({ }^{\circ} \mathrm{C}\right)$, sob as telas de sombreamento com diferentes percentagens no ambiente protegido com altura de $3,0 \mathrm{~m}$, no intervalo das 8 æ̀s 18h, ESALQ/USP, em Piracicaba, $\mathrm{SP}$

9 Resultados do Teste de Tukey, para as médias horárias de umidade relativa do ar (UR\%) coletadas nos ambientes internos (3,0 e 3,5m de altura) e no ambiente externo, no intervalo das 8 æ̀ $18 \mathrm{~h}$, ESALQ/USP, em Piracicaba, SP....

10 Resultados do Teste de Tukey, para as médias horárias de umidade relativa do ar (\%), sob as telas de sombreamento com diferentes percentagens no ambiente protegido com altura de $3,5 \mathrm{~m}$, no intervalo das 8 æ̀ 18h, ESALQ/USP, em Piracicaba, SP.

11 Resultados do Teste de Tukey, para as médias horárias de umidade relativa do ar (\%), sob as telas de sombreamento com diferentes percentagens no ambiente protegido com altura de $3,0 \mathrm{~m}$, no intervalo das 8 æ̀ 18h, ESALQ/USP, em Piracicaba, SP 
12 Resultados do Teste de Tukey para as médias horárias de radiação solar $\left(\mathrm{W} / \mathrm{m}^{2}\right)$ coletadas nos ambientes internos (3,0 e 3,5m de altura) e no ambiente externo, no intervalo das 8 às 18h, ESALQ/USP, em Piracicaba, SP

13 Resultado do Teste de Tukey para as médias horárias de temperatura de globo regro $\left(\mathrm{TGN}-{ }^{\circ} \mathrm{C}\right)$ e carga érmica radiante (CTR $-\mathrm{W} / \mathrm{m}^{2}$ ), medidos no interior dos ambientes com alturas de 3,5 e 3,0m, e no ambiente externo, no intervalo das 8 æ̀ $18 \mathrm{~h}$, ESALQ/USP, em Piracicaba, SP

14 Resultado do teste de Tukey para as médias horárias de temperatura de globo negro $\left({ }^{\circ} \mathrm{C}\right)$, sob as telas de sombreamento com diferentes percentagens no ambiente protegido com altura de $3,5 \mathrm{~m}$, no intervalo das 8 às 18h, ESALQ-USP, Piracicaba, SP.

15 Resultado do teste de Tukey para as médias horárias de temperatura de globo negro $\left({ }^{\circ} \mathrm{C}\right)$, sob as telas de sombreamento com diferentes percentagens no ambiente protegido com altura de $3,0 \mathrm{~m}$, no intervalo das 8 æ̀ $18 \mathrm{~h}, \mathrm{ESALQ}-U S P$, Piracicaba, SP

16 Resultado do teste de Tukey para as médias horárias de intensidade luminosa (lux) entre os ambientes com alturas de 3,5 e 3,0m, no intervalo das 8 à 18h, ESALQ/USP, em Piracicaba, SP.

17 Resultado do teste de Tukey para as médias horárias de intensidade luminosa (lux), relacionando a altura $(3,5 \mathrm{~m})$ e as diferentes telas de sombreamento, no intervalo das 8 à 18h, ESALQ-USP, Piracicaba, SP. 
18 Resultado do teste de Tukey para as médias horárias de intensidade luminosa (lux), relacionando a altura $(3,0 \mathrm{~m})$ e as diferentes telas de sombreamento, no intervalo das 8 æ̀ 18h, ESALQ-USP, Piracicaba, $\mathrm{SP}$

19 Resultado do Teste de Tukey para a variável altura da planta $(\mathrm{cm})$, em função dos sombreamentos e da altura do ambiente protegido (3,5m), da espécie $A$. fasciata, ESALQ-USP, Piracicaba, SP

20 Resultado do Teste de Tukey para a variável altura da planta $(\mathrm{cm})$, em função dos sombreamentos e da altura do ambiente protegido $(3,0 \mathrm{~m})$, da espécie $A$. fasciata, ESALQ-USP, Piracicaba, SP

21 Resultado do Teste de Tukey para a variável número de folhas, em função dos sombreamentos e da altura do ambiente protegido (3,5m), da espécie $A$. fasciata, ESALQ-USP, Piracicaba, SP

22 Resultado do Teste de Tukey para a variável número de folhas, em função dos sombreamentos e da altura do ambiente protegido $(3,0 \mathrm{~m})$, da espécie $A$. fasciata, ESALQ-USP, Piracicaba, SP

23 Resultado do Teste de Tukey para a variável largura da folha $(\mathrm{cm})$, em função dos sombreamentos e da altura do ambiente protegido $(3,5 \mathrm{~m})$, da espécie $A$. fasciata, ESALQ-USP, Piracicaba, SP

24 Resultado do Teste de Tukey para a variável largura da folha $(\mathrm{cm})$, em função dos sombreamentos e da altura do ambiente protegido $(3,0 \mathrm{~m})$, da espécie A. fasciata, ESALQ-USP, Piracicaba, SP............. 
25 Resultado do Teste de Tukey para a variável diâmetro da roseta $(\mathrm{cm})$, em função dos sombreamentos e da altura do ambiente protegido $(3,5 \mathrm{~m})$, da espécie $A$. fasciata, ESALQ-USP, Piracicaba, SP.

26 Resultado do Teste de Tukey para a variável diâmetro da roseta (cm), em função dos sombreamentos e da altura do ambiente protegido $(3,0 \mathrm{~m})$, da espécie A. fasciata, ESALQ-USP, Piracicaba, SP.

27 Resultado do Teste de Tukey para a variável altura da planta $(\mathrm{cm})$, em função dos sombreamentos e da altura do ambiente protegido $(3,5 \mathrm{~m})$, da espécie G. lingulata, ESALQ-USP, Piracicaba, SP.....

28 Resultado do Teste de Tukey para a variável altura da planta $(\mathrm{cm})$, em função dos sombreamentos e da altura do ambiente protegido $(3,0 \mathrm{~m})$, da espécie G. lingulata, ESALQ-USP, Piracicaba, SP.

29 Resultado do Teste de Tukey para a variável número de folhas, em função dos sombreamentos e da altura do ambiente protegido $(3,5 \mathrm{~m})$, da espécie G. lingulata, ESALQ-USP, Piracicaba, SP

30 Resultado do Teste de Tukey para a variável número de folhas, em função dos sombreamentos e da altura do ambiente protegido (3,0m), da espécie G. lingulata, ESALQ-USP, Piracicaba, SP......

31 Resultado do Teste de Tukey para a variável largura da folha $(\mathrm{cm})$, em função dos sombreamentos e da altura do ambiente protegido (3,5m), da espécie G. lingulata, ESALQ-USP, Piracicaba, SP 
32 Resultado do Teste de Tukey para a variável largura da folha $(\mathrm{cm})$, em função dos sombreamentos e da altura do ambiente protegido $(3,0 \mathrm{~m})$, da espécie G. lingulata, ESALQ-USP, Piracicaba, SP

33 Resultado do Teste de Tukey para a variável diâmetro da roseta $(\mathrm{cm})$, em função dos sombreamentos e da altura do ambiente protegido (3,5m), da espécie G. lingulata, ESALQ-USP, Piracicaba, $\mathrm{SP}$

34 Resultado do Teste de Tukey para a variável diâmetro da roseta $(\mathrm{cm})$, em função dos sombreamentos e da altura do ambiente protegido $(3,0 \mathrm{~m})$, da espécie G. lingulata, ESALQ-USP, Piracicaba, SP. 


\title{
DESENVOLVIMENTO DE BROMÉLIAS EM AMBIENTES PROTEGIDOS COM DIFERENTES ALTURAS E NÍVEIS DE SOMBREAMENTO
}

\author{
Autora: PAULETTI KARLLIEN ROCHA \\ Orientador: Prof. Dr. IRAN JOSÉ OLIVEIRA DA SILVA
}

\section{RESUMO}

O objetivo geral deste trabalho foi avaliar o efeito de diferentes alturas de ambientes protegidos e de diferentes níveis de sombreamento no cultivo de bromélias das espécies Aechmea fasciata e Guzmania lingulata. O experimento foi conduzido no período de 03 de abril de 2001 a 3 de abril de 2002, em dois ambientes protegidos, instalados, no sentido leste-oeste, na área experimental do Núcleo de Pesquisa em Ambiência (NUPEA), junto ao Departamento de Engenharia Rural, da Escola Superior de Agricultura "Luiz de Queiroz", Universidade de São Paulo, em Piracicaba, SP. Ambos os ambientes protegidos possuíam dimensões de 6,4m de largura por 17,5m de comprimento, com alturas diferenciadas, de 3,0m e de 3,5m. Esses ambientes possuíam cobertura plástica de polietileno de baixa densidade (PEBD), com $150 \mu$ de espessura. A avaliação dos níveis de sombreamento aplicados às plantas no interior dos ambientes foi viabilizada pelo uso de telas de polipropileno de cor preta que proporcionaram sombreamentos de 18, 40, 60 e $80 \%$. As mudas utilizadas no experimento foram obtidas através de micropropagação, e 
transplantadas para os vasos plásticos com uma idade aproximada de 90 dias em condições ex vitro. Avalio-se nos ambientes protegidos com diferentes alturas, a temperatura do ar, a umidade relativa, a temperatura de globo negro, a carga térmica radiante e a intensidade luminosa. Essa avaliação foi realizada pela leitura direta nos seguintes instrumentos: psicrômetros, termômetro de globo negro, anemômetro e luxímetro digital. Foram ainda realizadas coletas de dados de temperatura do ar, de umidade relativa e de radiação solar global, através de uma estação meteorológica automática. $O$ desenvolvimento das plantas, sob os diferentes níveis de sombreamento e as diferentes alturas dos ambientes, foi avaliado através do número de folhas, da altura das plantas, da largura das folhas e do diâmetro da roseta. Nas condições em que foi conduzido o experimento, concluiurse que não houve diferença significativa nos ambientes com diferentes alturas, quando relacionou-se a umidade relativa do ar, a temperatura do ar, a temperatura de globo negro, a carga térmica de radiação, a luminosidade e a radiação solar global. A $A$. fasciata, submetida aos vários níveis de sombreamento, mostrou um melhor desenvolvimento sob as telas de $40 \%$, enquanto que para $G$. lingulata as telas de 60 e $80 \%$ de sombreamento proporcionaram desenvolvimento semelhante das plantas. 


\title{
GROWTH OF BROMELIADS IN GREENHOUSES WITH DIFFERENT HEIGHTS AND LEVELS OF SHADING
}

\author{
Author: PAULETTI KARLLIEN ROCHA \\ Adviser: Dr. IRAN JOSÉ OLIVEIRA DA SILVA
}

\section{ABSTRACT}

The objective of this research was to evaluate the effect of different greenhouses heights and levels of shading on the growth of Aechmea fasciata and Guzmania lingulata (Bromeliaceae). The experiment was done from march 26 'th of 2001 to april third of 2002, in two greenhouses, built in east-west orientation, at the experimental area of Nucleos of Environment Research NUPEA, Rural Engineering Department, "Luiz de Queiroz" College of Agriculture, University of São Paulo, Piracicaba, Brazil.

Greenhouses measured: $6.4 \mathrm{~m}$ in width, $17.5 \mathrm{~m}$ in length and heights of $3.0 \mathrm{~m}$ and $3.5 \mathrm{~m}$. They were covered with $150 \mu$ thick low density polyethylene (PEBD). Black polypropylene cloth providing shading of $18 \%, 40 \%, 60 \%$, and $80 \%$ was used. The plants used in the experiment were obtained through micropropagation and transplanted to plastic pots at approximately 90 days after ex vitro culture. The air temperature, the relative humidity, the black globe temperature, the radiant thermal load, and light intensity were evaluated inside the greenhouses. These evaluations were carried out through the direct reading from the following instruments: psycrometers, black globe thermometer, anemometer and digital luximeter. Air temperature, relative humidity and global 
solar radiation were also obtained through sensors connected to an automatic meteorological station. The development of the plants under different levels of shading and different heights was evaluated according to the number of leaves, height of plants, width of leaves, and the diameter of the rosette. Under the conditions used for the experiment, it can be concluded that the $3.5 \mathrm{~m}$ high greenhouse showed lower air relative humidity when compared to the $3.0 \mathrm{~m}$ high greenhouse. Plants of $A$. fasciata growing under different levels of shading had a better development under $40 \%$ cloths, while G. lingulata showed a more vigorous grouth under $60 \%$ and $80 \%$ of shading. 


\section{INTRODUÇÃO}

As bromélias, família Bromeliaceae, contam com quase 3.000 espécies, típicas das Américas. No Brasil, elas crescem em profusão, especialmente na mata Atlântica. As espécies brasileiras são extremamente apreciadas em todo o mundo, tanto pelas cores, pelas formas e pelos desenhos da própria planta, quanto pela sua inflorescência; daí o grande interesse ornamental que despertam, justificando o aumento de sua produção por muitos produtores rurais, e a consideração de ser a bromélia planta ornamental por excelência. Outro fator que contribuiu para essa popularidade, além de sua beleza, foi o fato de ser uma planta que não requer muitos cuidados e tem grande resistência.

Denominadas popularmente como "gravatás", as bromélias brasileiras já eram conhecidas pelos nossos índios, que chamavam também de "carauá", "carandá" ou "caraguá" (Paula, 2000). Segundo Reitz (1983), as bromélias foram consideradas focos de mosquitos transmissores da malária, devido ao formato das folhas, que facilita o acúmulo de água. Por esse motivo, muitas áreas foram desmatadas, a fim de eliminar as bromélias. Todavia, após a destruição de várias áreas, não se observou a esperada diminuição da densidade dos transmissores da malária.

No Brasil, apenas no final do século $X X$, as bromélias passaram a ser novamente admiradas e cultivadas em escala comercial, graças aos trabalhos de pesquisadores, colecionadores, paisagistas e outros. Hoje, as bromélias estão em pleno processo de popularização (Paula, 2000). Seu cultivo ganhou 
impulso entre os produtores, sendo hoje uma atividade economicamente rentável e uma boa opção na floricultura.

Segundo Matsunaga (1995), o Brasil tem potencial para ampliar as exportações com a produção de plantas tropicais como helicônia, antúrio, orquídea e bromélia. O crescente aumento na produção comercial de bromélias traz vantagens tanto para o produtor, que tem um aumento de renda, quanto para o meio ambiente, reduzindo o extrativismo predatório de algumas espécies que se encontram em extinção.

O mercado brasileiro de flores e de plantas ornamentais movimenta, anualmente, cerca de um bilhão de reais, sendo o Estado de São Paulo, cuja produção é voltada, quase exclusivamente, para o mercado interno, responsável por $70 \%$ desse montante. Segundo especialistas do setor, há uma expectativa de crescimento anual de $20 \%$ (Arruda et al., 1996). As estimativas e os números que aparecem na imprensa são, com freqüência, desencontrados. Há afirmações de que o setor movimentou mais de 1 bilhão de dólares em 1999 e que seu crescimento, na década de 1990 , ocorreu a uma taxa de $25 \%$ ao ano. Outras informações falam em valores de mercado de 2,7 bilhões de reais e crescimento anual de $20 \%$. A falta de precisão nas informações, na verdade, é reflexo da falta de organização do setor e da forma tradicional como o negócio é tocado por grande parte dos produtores e por outros elementos da cadeia de comercialização (FNP, 2001). Segundo o Instituto Brasileiro de Floricultura (2002), o varejo brasileiro do setor florícola apresentou um faturamento de US\$ 1,5 bilhão em 1999, o que significa crescimento de 89\%, em relação a 1995.

Dentre as dificuldades que os produtores têm encontrado, observa-se a carência de informações sobre a influência da estrutura dos ambientes protegidos, em relação ao microclima gerado no seu interior, e do sombreamento a ser utilizado para um melhor desenvolvimento das plantas.

O grande desconhecimento dos aspectos estruturais, de geometria e forma, e dos aspectos térmicos de estruturas, para a produção em ambiente protegido, faz com que técnicos da área questionem os princípios básicos da construção. 
A falta de estudos quanto ao dimensionamento dos ambientes protegidos, relacionado ao microclima formado no interior deles, em diferentes estações do ano, dificulta o planejamento adequado e a adaptação regionalizada, que impedem o desenvolvimento de novas técnicas .

Considerando os fatores altura dos ambientes protegidos e luminosidade, 0 presente trabalho justifica-se no sentido de fornecer dados importantes para 0 cultivo comercial de bromélias.

O objetivo deste trabalho foi avaliar a influência de alturas de ambientes protegidos (3,0 e 3,5m - pé-direito) no microclima gerado em seu interior, e a influência de quatro telas com diferentes níveis de sombreamento no desenvolvimento de duas diferentes espécies de bromélias. 


\section{REVISÃO DE LITERATURA}

\subsection{Bromélias}

\subsubsection{Origem e História}

As bromélias, família Bromeliaceae, são plantas típicas das zonas tropicais e subtropicais das Américas; atualmente, dividem-se em três subfamílias. Habitam quase todos os ecossistemas observados desde o Chile até a parte sul dos Estados Unidos (a única exceção fica por conta da Pitcairnia feliciana, exclusiva do Golfo de Guiné, na África). Desse modo, podemos encontrar bromélias tanto ao nível do mar, quanto em altitudes acima de $4.000 \mathrm{~m}$, em zonas de elevada precipitação, ou em áreas semi-áridas e até desérticas (Leme, 1984).

No Brasil, encontram-se em todas as regiões, com maior diversidade na região da Mata Atlântica, entre Santa Catarina e Bahia. Dos 54 gêneros e cerca de 2.663 espécies que constituem a família Bromeliaceae, $70 \%$ dos gêneros e mais de $40 \%$ das espécies ocorrem no Brasil (Paula, 2000).

As bromélias caracterizam-se por serem plantas herbáceas, epífitas, perenes, com folhas geralmente formando uma roseta, que, na grande maioria das espécies, acumula água (Paula, 2000). Por esse fato, associou-se às bromélias o problema da malária. Adolpho Lutz, encarregado de pesquisar a relação malária-bromélia, encontrou larvas de mosquitos nos pequenos tanques das Bromeliaceas o que o levou a, em 1983, concluir que "mosquitos criados em gravatás podem transmitir malária". A partir daí, foi realizado um estudo 
taxonômico das Bromeliaceas, efetuado pelo Pe. Raulino Reitz, especialista nessa família. Após a análise dos dados, ficou demostrado que não existem espécies preferenciais de Bromeliaceas para a ovoposição das larvas dos mosquitos transmissores de malária; mas também ficou esclarecido que existem "condições ecológicas necessárias" para o desenvolvimento completo dos mosquitos. Como conseqüência, muitas dessas plantas foram destruídas por dois métodos: retirada manual e desmatamento; já em outra tentativa de destruição das Bromeliaceas foram utilizados ervicidas. Porém, não se obtiveram resultados positivos na eliminação do transmissor, que continuou em elevada densidade (Reitz, 1983).

As bromélias possuem, na superfície da folha, tricomas, chamados escamas peltadas ou foliares, que conferem a essas plantas capacidade singular de absorção de água e nutrientes, até mesmo do ar; daí o cuidado que se deve ter quanto ao uso de adubos e de defensivos químicos (Paula, 2000). Os pêlos escamosos, encontrados nas folhas das bromélias, são responsáveis pela alimentação, sugando a água e, com ela, as substâncias alimentícias em solução (Reitz, 1983).

Dependendo do ecossistema envolvido, as bromélias podem vegetar em vários tipos de solo (terrestres); sobre acúmulos orgânicos (epífitas) e diretamente sobre rochas nuas (rupícolas). A maioria das espécies conhecidas são epífitas, sendo, por isso, erroneamente consideradas, pelos leigos, como parasitas. $\mathrm{Na}$ verdade, as raízes dessas plantas têm mera função de sustentação e as espécies epífitas apenas utilizam os galhos de outros vegetais para alcançar uma posição estratégica na floresta e receber maior luminosidade, drenagem adequada e carga acentuada de ar circulante.

As bromélias conseguiram, durante sua evolução, adaptarem-se à mais diferentes condições de clima e de luminosidade. O sucesso na escolha do ambiente ideal varia de gênero para gênero. Na mata, as bromélias fixam-se de acordo com a luminosidade e a umidade atmosférica: 
a) Heliófitas: espécies exigentes de luz, geralmente afixadas nos galhos superiores e médios das árvores mais altas;

b) Esciófitas: tolerantes à sombra, espécies sempre afixadas a pouca altura ou estabelecidas no solo ou em pedras;

c) Mesófitas ou indiferentes: afixadas em troncos, em galhos médios ou inferiores das árvores.

A abundância e a distribuição das espécies de Bromeliaceas são muito variáveis, de acordo com as diferentes situações topográficas da região.

Tanto a falta, quanto o excesso de luz podem prejudicar as bromélias. Os sintomas de falta de luz são folhas macias, caídas, mais longas que o normal; já os de excesso de luz são folhas amareladas ou amarronzadas, ressecadas, mais curtas que o normal da espécie e queimaduras diversas (Reitz, 1983; Paula, 2000).

Estudo feito em uma população da bromélia Neoregelia johannis, na mata Atlântica da llha Grande, no litoral fluminense, mostrou diferenças acentuadas, entre os indivíduos, no tamanho e na coloração das folhas. Carvalho et. al (1998) e Carvalho \& Rocha (1999) provaram existir relação direta entre a intensidade de luz do ambiente e as características das folhas desse vegetal. Dependendo da quantidade de luz que incida sobre a planta, ela poderá ter determinada coloração (decorrente da concentração de pigmentos), e tamanho e formato próprios.

Essa capacidade de adaptação dos vegetais a ambientes heterogêneos é conhecida como "plasticidade". As características do local onde a planta está fixada (seu microhabitat) determinam o grau de insolação ou de sombreamento sobre ela. As bromélias que habitam locais mais sombreados têm folhas mais compridas e mais estreitas (mas com maior superfície) do que as que vivem em áreas expostas ao sol. As plantas fixadas em áreas de sombra aumentam sua superfície foliar para receber maior quantidade de luz solar, já que esta é essencial para certas atividades metabólicas vegetais (como fotossíntese e crescimento). Já as bromélias que vivem sob sol direto não precisam se 'esticar' 
em busca de luz. Ao contrário, elas reduzem a área foliar, para evitar que a insolação e a temperatura de seu microhabitat causem um excesso de evaporação da água presente nas folhas Carvalho et al (1998) e Carvalho \& Rocha (1999).

A umidade ideal para cada espécie é a predominante da região, quando a planta ocorre na natureza. Contudo, de modo geral, pode-se dizer que se desenvolvem satisfatoriamente entre $15^{\circ}$ e $30^{\circ} \mathrm{C}$, em locais ventilados e com alta umidade relativa do ar (Paula, 2000). O mesmo autor afirma que, apesar de as bromélias apreciarem alta umidade relativa do ar, não toleram excesso de água junto ao sistema radicular. Por isso, é recomendável pulverizar água nas folhas, quando a temperatura estiver acima de $35^{\circ} \mathrm{C}$.

\subsubsection{Morfologia}

Segundo Reitz (1983), as Bromeliáceas possuem:

a) Raízes: nas bromélias epífitas, as raízes servem principalmente como elemento de fixação, pois a nutrição é feita por pêlos escamosos;

b) Caule: todas as bromeliáceas têm caule, mas, como na maioria dos casos é muito curto, torcido e densamente coberto por folhas, formando uma roseta, tornou-se praxe denominá-las "acaules";

c) Folhas: costumam ter na base uma parte alargada, chamada bainha, a qual esta, na maior parte das bromélias epífitas, desempenha um papel importante na alimentação da planta. São providas de pêlos escamosos que absorvem o alimento. Sua inserção no caule e a disposição das bordas da bainha ocorrem de tal modo, que, em muitos casos, formam um receptáculo que permite guardar água. A coloração da bainha é muito variada nas diferentes espécies. Também o é a lâmina foliar: ligulada, triangular-aguda, linear, cilíndrica. Quanto à consistência, há várias, desde o tipo de folhas flácidas, dobradas, até as extremamente duras e resistentes. Algumas espécies apresentam 
margens espinhosas. A cor das folhas é, em geral, verde ou verdeacinzentada, em virtude do revestimento com escamas brancacentas; algumas espécies tornam se avermelhadas, quando expostas ao sol intenso; outras aparecem verdes, ou pouco pintadas de roxo, quando vegetam na sombra. Podem ainda aparecer com as lâminas foliares longitudinalmente estriadas nas cores verde e amarela;

d) Inflorescência: simples ou composta, apresentando, em geral, brácteas belamente coloridas;

e) Flores: todas são trímeras, nascem na axila de uma bráctea; são hermafroditas ou essencialmente unissexuadas;

f) Fruto: em baga ou cápsula;

g) Sementes: nuas, aladas ou plumosas.

\subsubsection{Classificação taxonômica}

De acordo com Paula (2000), a classificação da família Bromeliaceae iniciou-se com Linnaeus, por meio do estabelecimento do gênero Bromelia, constituído de 14 espécies. Posteriormente, Jussieu, em 1789, estabeleceu a tribo Bromelia e a família Bromeliaceae. O mesmo autor relata que a classificação considerada mais completa é a proposta por Smith \& Downs ${ }^{1}$.

A família Bromeliaceae é dividida em 3 subfamílias:

a) Subfamília Bromelioideae (ex. Gênero: Aechmea - 217 espécies ocorrentes no Brasil);

b) Subfamília Tillandisiodeae (ex. Gênero: Guzmania - 175 espécies ocorrentes no Brasil);

c) Subfamília Pitcairnioideae (ex. Gênero Pitcairnia - espécies ocorrentes na África).

${ }^{1}$ SMITH, L.B., DOWNS, R. J. Bromeliaceae, subfamily Bromelioideae. In: Flora neotropica. New York: Botanical Garden, 1979. p.1493-2142. (Flora neotropica. Monograph, 14, part 3). 


\subsubsection{Aechmea (Bromelioideae)}

A espécie mais conhecida é a $A$. fasciata Baker, exclusiva da Floresta Tropical Atlântica do Rio de Janeiro e do Espírito Santo (Reitz, 1983; Willians \& Hodgson, 1990). Foi introduzida na Europa em 1826, e hoje pode ser encontrada em inúmeros países.

São herbáceas perenes, epífitas, acaule, de folhagem e florescimento vistosos, de 30 a $40 \mathrm{~cm}$ de altura. Apresentam folhas em roseta foliar aberta com cisterna, laminares, coriáceas, com espinhos. São marmorizadas de verde com escamas cinza-prateadas, principalmente na face inferior das folhas. Inflorescência simples, vistosa, forma piramidal e com longa durabilidade, flores com sépalas, apresentando um espinho no ápice, ovário ínfero, fruto baga, vivamente colorido (Reitz, 1983; Lorenzi, 1999; Paula, 2000).

A bromélia dessa espécie propaga-se por rizomas a partir da base, apresenta folhas de 10 a 20 em roseta cilíndrica ou levemente fuliforme, mede de 30 a $100 \mathrm{~cm}$ de comprimento e possui, de ambos os lados escamas pálidas.

Segundo Kämpf (2000), as Bromeliaceaes de folhas coloridas ( $A$. fasciata) são plantas de meia sombra e necessitam de nível médio de iluminação, entre 500 e 1.000 lux.

Conforme Leme (1984), a espécie $A$. fasciata é integrante do subgênero Platyaechmea, classificada pela primeira vez, em 1928 como Bilbergia fasciata Lindley.

Segundo Reitz (1983), a A. fasciata apresenta variedades naturais:

a) A. fasciata var. fasciata, com folhas verdes igualmente coloridas (concolores), com faixas brancas transversais;

b) A. fasciata var. pruinosa, com folhas branco-farinosas;

c) A. fasciata var. purpurea, com folhas vermelho-purpúreas e

d) A. fasciata var. flavi-vittata, cujas folhas têm listras longitudinais alternantes verdes e amarelas. 
Atualmente, em São Paulo, a A. fasciata (Figura 1a) é a bromélia mais comercializada, seguida por Guzmania (var. compacta, empire, magenta, cherry e denise), segundo Vitari (1984).

\subsubsection{Guzmania (Tillandsioideae)}

As espécies desse gênero, cerca de 175, além de um grande número de híbridos comerciais (Paula, 2000) ocorrem nas três Américas. Segundo Willians \& Hodgson (1990), a G. lingulata (Figura 1b), representante dessa subfamília, é encontrada no Oeste da Índia, na América Central e no Brasil.

São plantas herbáceas perenes, robustas, muito variáveis, de florescimento decorativo, de 20 a $30 \mathrm{~cm}$ de altura, apresentam folhas laminares em roseta aberta, sem espinhos, formando cisterna. Inflorescência sobre haste ereta, compostas, com brácteas escapais vivamente coloridas (verde, amarela, laranja, rósea e vermelha), que usualmente se estendem acima da roseta; as flores têm pétalas brancas ou vermelhas. São geralmente epífitas (Willians \& Hodgson, 1990; Lorenzi, 1999; Paula, 2000).

A maior parte das Guzmanias são encontradas em locais com pouca luminosidade (Willians \& Hodgson, 1990). Segundo Kämpf (2000), Bromeliaceaes de folhas verdes como esta espécie, são plantas de sombra e toleram baixo nível de iluminação, entre 300 e 500 lux.

(a)

(b)
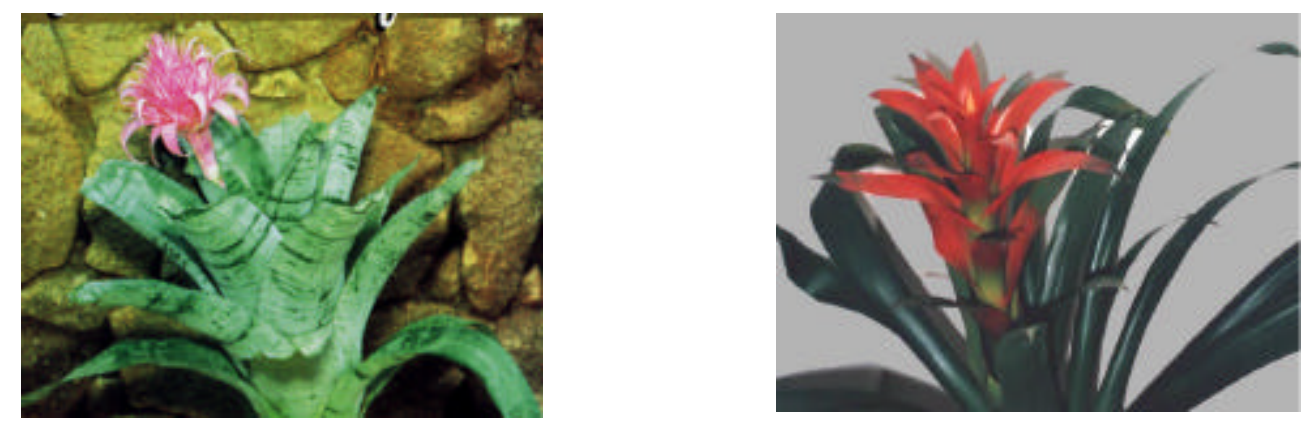

Figura 1 - Fotos das duas espécies de bromélias adultas utilizadas no experimento, (a) A. fasciata e (b) G. lingulata 


\subsubsection{Produção comercial de bromélias}

A produção de bromélias em escala comercial é uma atividade viável e tem-se desenvolvido bastante no Brasil, seguindo os passos de outros países, como os Estados Unidos, a Holanda e a Bélgica. Seu cultivo ganhou impulso nos últimos tempos, constituindo, hoje uma atividade economicamente rentável e uma boa opção na floricultura. Esse crescente aumento na produção comercial de bromélias traz vantagens tanto para o produtor, que tem aumento de renda, quanto para o meio ambiente, reduzindo o extrativismo predatório de algumas espécies que se encontram em perigo de extinção; tal situação poderá ser amenizada, na medida que cresce a consciência da necessidade de preservar a natureza e incrementar a produção comercial dessas plantas. Todavia ainda são poucas as informações quanto a essa atividade comercial (Andrade \& Demattê, 1999; Kanashiro, 1999).

Segundo estudo de Andrade \& Demattê (1999), sobre a produção e a comercialização de bromélias nas regiões Sul e Sudeste do Brasil, os maiores produtores de bromélias estão assim distribuídos: oito no Estado de São Paulo, dez no Rio de Janeiro, dois no Rio Grande do Sul e sete em Santa Catarina. A análise dos dados obtidos mostrou que a produção comercial de bromélias se intensificou no nosso país, a partir da década de 90. Para a grande parte do grupo estudado, com destaque para o Rio de Janeiro e para o Sul, o início do cultivo comercial derivou da paixão já existente em colecionar bromélias e orquídeas, ou da atividade relacionada ao paisagismo, já que percebeu a grande possibilidade do uso de bromélias em jardins.

De acordo com Estrelas Tropicais, Globo Rural (2000), os maiores produtores de bromélias estariam no Estado de São Paulo, sendo a empresa Bromélias Rio, sediada em Campinas, com uma área de produção em estufa de 10ha, considerada o maior produtor, com a produção média de 40 mil vasos/mês. Outro grande produtor está em Holambra: possui uma área de 8,5ha de estufas e produção média de 40 a 50 mil vasos/mês. 
Os dados obtidos no estudo de Andrade \& Demattê (1999) mostram que os produtores menos especializados e que usam menos tecnologia optam pelo cultivo por meio de sementes colhidas de matrizes próprias; já os que buscam especialização e melhores recursos tecnológicos trabalham com material de propagação mais tecnificado, como aquele proveniente de cultivo de meristemas, ou de sementes selecionadas. Esta opção, além de uniformizar as plantas, pois normalmente são híbridas, diminui o ciclo de produção.

\subsection{Cultivo em ambiente protegido}

O cultivo de flores e de hortaliças em ambientes protegidos é uma atividade que se encontra em franca expansão no Brasil. A principal vantagem dessa técnica consiste na possibilidade de produção nos períodos de entressafra, o que permite maior regularização da oferta e melhor qualidade dos produtos (Sentelhas \& Santos, 1995).

Destaca-se, ainda, como estratégia para superar limitações climáticas, especialmente se considerarem a sua eficiência na captação da energia radiante e o melhor aproveitamento, pelas plantas da temperatura e da água disponível e dos nutrientes (Slater, 1983).

No Brasil, diversas pesquisas têm confirmado tal hipótese, indicando que, mesmo em ambientes protegidos não-climatizados, os rendimentos superam aqueles obtidos no campo. Adicionalmente, os produtos colhidos apresentam melhor qualidade, as plantas consomem menos água, diminui-se a lixiviação dos nutrientes e melhora-se o aproveitamento da radiação solar (Martins et al., 1999).

O descobrimento do polímero de polietileno, no final da década de 1930, e sua subseqüente introdução na agricultura, no início da década de 1950, revolucionaram a produção comercial de algumas hortaliças em diversas regiões do mundo (Lamont Júnior, 1996). No Brasil, a introdução dessa tecnologia remonta à década de 1970, com a instalação de projetos pioneiros 
de cultivo de tomate, pelo Instituto Adventista Agroindustrial de Manaus, no Amazonas, e o cultivo de pepino japonês por produtores cooperados da extinta Cooperativa Agrícola de Cotia, na região do cinturão verde da cidade de São Paulo (Martins, 1996; Kumagaia, 1991).

Segundo Goto (1997), a utilização de plásticos na olericultura ocorreu pela primeira vez em grande escala no Brasil, no início da década de 1970, como 'mulching' na cultura do morango. De acordo com o levantamento efetuado em 1999, cerca de 1.390ha foram cultivados com hortaliças em ambientes protegidos no Brasil, no ano de 1998. São Paulo, Paraná e Rio Grande do Sul foram os estados com maior área de produção (Vecchia \& Koch, 1999).

Segundo o Instituto Brasileiro de Floricultura (2000), a produção brasileira de flores e de plantas ornamentais, inicialmente concentrada no Estado de São Paulo, tem se expandido por todo o país, com cultivos nos Estados do Rio de Janeiro, Minas Gerais, Santa Catarina, Paraná, Rio Grande do Sul, Pernambuco, Ceará e no Norte do país.

A Tabela 1 mostra a distribuição da produção no Brasil e revela que somente $20 \%$ da área total é cultivada em estufas.

Entre as culturas produzidas em ambientes protegidos, destaca-se a floricultura como a atividade que mais tem investido em tecnologia no país, devido, principalmente, ao alto valor econômico que os produtos atingem e ao elevado nível de exigência do mercado consumidor (Furlan, 2001). 
Tabela 1 - Distribuição da produção de flores no Brasil, número de produtores, área cultivada e vendas por região/estado - 1999.

\begin{tabular}{cc|cccccc}
\hline $\begin{array}{c}\text { Região/ } \\
\text { Estado }\end{array}$ & $\begin{array}{c}\text { Produtores } \\
\mathrm{N}^{\circ}\end{array}$ & Campo & Estufa & Total & $\begin{array}{c}\text { Participação } \\
\%\end{array}$ & $\begin{array}{c}\text { R\$ } \\
\text { milhões }\end{array}$ & $\begin{array}{c}\text { Participação } \\
\%\end{array}$ \\
\hline SP & 1.500 & 2.748 & 709 & 3.457 & 71,3 & 240,0 & 74,5 \\
RJ & 100 & 70 & 10 & 80 & 1,6 & 8,0 & 74,5 \\
MG & 350 & 100 & 18 & 118 & 2,4 & 11,8 & 3,7 \\
Total SE & 1.950 & 2.918 & 737 & 3.655 & 75,4 & 259,8 & 80,6 \\
PR & 90 & 100 & 80 & 180 & 3,7 & 9,0 & 2,8 \\
SC & 115 & 300 & 40 & 340 & 7,0 & 17,0 & 5,3 \\
RS & 270 & 520 & 50 & 570 & 11,8 & 28,0 & 8,7 \\
Total S & 475 & 920 & 170 & 1.090 & 22,5 & 54,0 & 16,8 \\
NE & 80 & 30 & 30 & 60 & 1,2 & 5,0 & 1,6 \\
CO & 20 & 20 & 5 & 25 & 0,5 & 2,0 & 0,6 \\
N & 20 & 10 & 10 & 20 & 0,4 & 1,5 & 0,5 \\
\hline Total & 2.545 & 3.898 & 852 & 4.850 & 100,0 & 322 & 100,0 \\
Fonte: Augusto Aki & & & & & & &
\end{tabular}

Com o aumento da produção de flores e de plantas ornamentais em ambientes protegidos, faz-se necessária a geração de novas informações tecnológicas a respeito do manejo desses ambientes.

\subsection{Ambiência em cultivo protegido}

O uso de coberturas plásticas é responsável por alterações em diversos elementos meteorológicos, tornando viável a produção de vegetais em épocas, ou em lugares, cujas condições climáticas são críticas. A radiação solar é um dos principais elementos alterados pelo uso de coberturas plásticas. No entanto nem todas as modificações microclimáticas são benéficas aos cultivos (Farias et al., 1993 e Sentelhas \& Santos, 1995) . 
O controle microclimático eficiente, durante o verão, é um dos maiores desafios para produtores que utilizam o cultivo em ambiente protegido, no sentido de obterem produtos de melhor qualidade, fora da época convencional. O cultivo no verão, apesar de ser favorecido pelo efeito "guarda-chuva", proporcionado pelo ambiente protegido, enfrenta problemas sérios de temperatura elevada do ar, que pode causar até a morte da planta (Furlan, 2001).

Em alguns casos, o manejo do ambiente pode assegurar a obtenção de uma planta de qualidade superior; em outros, a modificação do ambiente é indispensável para possibilitar a viabilidade econômica do empreendimento.

A radiação solar é a principal responsável pelas modificações microclimáticas ocorridas no interior dos ambientes protegidos, influenciando, diretamente, a temperatura e a umidade relativa do ar.

A temperatura no interior de ambientes protegidos está diretamente ligada às condições ambientais internas e externas, sendo verificados os maiores valores de temperatura do ar geralmente próximos ao meio-dia. Esse padrão pode ser alterado, em função da radiação solar incidente (Farias, 1991).

A temperatura está relacionada tanto ao crescimento, devido ao seu efeito na velocidade das reações bioquímicas e dos processos internos de transporte de seiva, quanto ao desenvolvimento normal das plantas. Tais processos só ocorrem, de forma adequada, segundo certos limites térmicos, sendo que diferentes espécies toleram distintos limites de temperatura (Sentelhas et al., 1998).

De acordo com Alpi \& Tognoni (1991), as variações de temperatura no interior de ambientes protegidos, notadamente no sentido vertical, são causa direta dos fenômenos de transmissão de calor por irradiação, condução e, principalmente, convecção. Sendo assim, ocorre um gradiente de temperatura no interior da estufa, variando, durante o dia, de um mínimo, próximo ao solo, até um máximo, contíguo ao teto. 
Avaliando o efeito de diferentes manejos de cortinas e de sistemas de resfriamento na redução da temperatura do ar no interior de ambientes protegidos, Furlan (2001), concluiu que a combinação entre o manejo de cortinas e a nebulização foi o sistema mais eficiente na redução da temperatura do ar.

A variação da umidade do ar no interior dos ambientes protegidos depende, principalmente, da temperatura do ar e da ventilação. Por sua vez, a temperatura do ar varia, principalmente, em função da densidade de fluxo de radiação solar incidente e da própria ventilação, a qual depende da área, da localização e do manejo das aberturas, bem como da velocidade de troca do ar entre o interior e o exterior do ambiente (Buriol, 2000).

De acordo com Sganzerla (1995), quanto maior a relação volume/área de uma estufa, maiores serão os contrastes na umidade relativa e na temperatura do ar. Ambientes protegidos com pé-direito baixo apresentam maiores problemas com a elevação de temperatura, tornando o controle mais difícil (Furlan, 2001).

Estudando as alterações microclimáticas em ambientes protegidos, em função do pé-direito (3,0 e 3,5m), Nascimento \& Silva (1999), encontraram valores superiores de temperatura do ar para o ambiente com menor altura, sendo essa diferença mais significativa no intervalo das 10 æ̀ $16 \mathrm{~h}$, quando a redução da temperatura do ar, em relação ao ambiente de maior altura, chegou a $0,58^{\circ} \mathrm{C}$. A umidade relativa do ar manteve-se em média $2,0 \%$ maior no ambiente com maior altura.

Seemann (1979), afirmou que a temperatura do ar, no interior dos ambientes protegidos, difere das externas e depende da densidade de fluxo de radiação solar incidente no interior deles, além do manejo. A variação de temperatura depende também do tamanho do ambiente quanto do volume de ar a ser aquecido.

O efeito da cobertura plástica é maior sobre as temperaturas máximas; atribuem o fato à íntima relação entre a temperatura e a radiação solar, ao 
menor volume de ar a ser aquecido e ao efeito eficiente dos ambientes, que impedem o resfriamento do mesmo, causado pela ação dos ventos (Tanaka \& Genta,1982).

O menor volume de ar a ser aquecido no interior dos ambientes e a redução da influência dos ventos no resfriamento do ambiente fazem com que durante o dia, a radiação solar incidente compense as perdas de calor que ocorrem através da cobertura, permitindo atingir temperaturas mais elevadas que no ambiente externo (Martinez Garcia, 1986; Camacho, 1995).

\subsection{Ventilação}

A ventilação natural é um dos principais processos de modificação do microclima interno de uma construção que visa à exploração agrícola. O aproveitamento dos ventos predominantes da região e das características construtivas de uma estrutura são fatores primordiais para a eficiência do sistema, no condicionamento do ambiente interno.

Um dos grandes problemas em produções cultivadas em ambiente protegido é o excesso de calor interno, acumulado ao longo do dia, em função da radiação solar incidente. Diante disso, em países tropicais, o emprego de mecanismos que favoreçam o uso de ventilação natural maximiza a qualidade do ambiente interno, promovendo uma mudança nas características psicrométricas do ar. As diferenças entre a temperatura do ambiente externo e a do interno promovem a variação na pressão, que, por conseqüência, alteram o fluxo de ar no ambiente de produção (Camargo et al., 2000).

Segundo Cermenõ (1994), Martins \& Gonzales (1995), Oliveira (1997), a ventilação natural é um fator extremamente importante, no que se refere à renovação do ar no interior dos ambientes. Com a renovação, o ar atua sobre a temperatura e a umidade relativa, evitando o calor excessivo, durante o dia, e assegurando a taxa mínima de $\mathrm{CO}_{2}$, o principal elemento químico para o crescimento dos vegetais. 
Há dois tipos de ventilação, a natural e a forçada. A natural depende basicamente do formato das instalações e das características climáticas regionais. A ventilação forçada ocorre por meio de exaustores, ou ventiladores, dimensionados e posicionados estrategicamente nas estufas (Hardoim, 1995).

A ventilação natural no interior das instalações, ocorre pelo aquecimento diferencial do ar, ou pela ação dos ventos. Esse aquecimento diferencial do ar, que ocasiona a ventilação, é conhecido como efeito "termo-sifão". De acordo com Rault (1990), é necessário o desenvolvimento de ambientes que possuam o efeito "termo-sifão" eficiente, pois, em regiões de clima quente, a temperatura do ar no interior deles pode vir a prejudicar o desenvolvimento das plantas. Outra grande vantagem de se utilizar ambientes com sistemas de ventilação natural é que o custo de instalação e de manutenção desse tipo de sistema é bem inferior ao dos sistemas mecânicos automáticos.

Desenvolvendo um novo modelo de estufa que se adaptasse às condições climáticas do mediterrâneo, Brun \& Lagier (1985), concluíram que a estufa que se utilizava do efeito "termo-sifão" eficazmente foi a que apresentou melhor rendimento da cultura e melhor índice de controle de temperatura do ar.

Comparando diferentes modelos de estufas, para determinar qual a mais eficiente em regiões de clima quente, Feuilloley et al. (1990) e Rault (1990) concluíram que as estufas com abertura no teto e nas paredes são as mais eficientes, pois geram uma excelente circulação do ar.

Avaliando o sistema de ventilação natural com o uso de janela zenital, em ambientes protegidos, Kai et al. (2000), verificaram que a condição de maior ventilação natural, proporcionada pela abertura da janela zenital, promoveu valores mais reduzidos de temperatura do ar, quando comparados aos produzidos sob a condição da janela enital fechada. Reforçaram, assim, os estudos realizados por Feuilloley et al. (1990) e Rault (1990).

Além da ventilação, outros sistemas são utilizados como forma complementar para reduzir a temperatura no interior dos ambientes protegidos, tais como sombreamento, irrigação e umedecimento (Martins et al. 1995). 


\subsection{Sistema de resfriamento adiabático evaporativo por nebulização}

O resfriamento evaporativo é um processo adiabático, ou seja, que não gera ganho ou perda de calor; portanto a energia requerida para evaporar a água é suprida pelo ar, com conseqüentes umedecimento e redução da temperatura do ar (Abreu et al., 1999).

De acordo com Baêta \& Souza (1997), no resfriamento evaporativo adiabático, nenhum calor externo é adicionado durante o processo, e o conteúdo total de calor não varia. Há simplesmente uma mudança ambiental que melhora, de forma considerável, as condições de conforto.

Estudando o efeito do sistema de resfriamento por nebulização em ambiente protegido, Montero et al. (1990) usaram, em seu experimento, dois ambientes protegidos, cobertos com um filme multi-EVA e uma tela de sombreamento aluminizada, transmitindo $45 \%$ da radiação solar incidente. As dimensões dos ambientes eram 19,2 x 12,0m. O sistema de nebulização foi instalado em um dos ambientes protegidos, utilizando-se 26 bocais. Os resultados mostraram que 0 resfriamento evaporativo dos ambientes protegidos abaixou a temperatura do ar em $3,0^{\circ} \mathrm{C}$, na média, quando comparado ao ambiente protegido-controle. A redução máxima de temperatura, durante dias de sol, foi de $5,0^{\circ} \mathrm{C}$, com o conseqüente aumento da umidade relativa, que se manteve em $85 \%$, nos ambientes com sombreamento.

A principal vantagem do sistema de resfriamento por nebulização é a uniformidade de resfriamento em todo o ambiente, eliminando a necessidade de ventilação forçada, o que resulta em um resfriamento mais efetivo, adaptável a ambientes com estruturas mais simples. Entretanto apresenta, como desvantagens, o alto custo de instalação, a necessidade do uso de água de boa qualidade e o aumento da ferrugem nas estruturas metálicas e nos equipamentos do ambiente protegido (Martins et al., 1995; Furlan, 2001).

A eficiência do processo de resfriamento, segundo Martins et al. (1995), depende das condições de radiação solar, da temperatura externa, da umidade 
relativa interna do ar e da ventilação do ambiente. Obviamente, a temperatura interna do ambiente protegido dependerá, além desses fatores, da qualidade do filme plástico utilizado.

Segundo Alpi \& Tognoni (1991), uma das vantagens do sistema de resfriamento por nebulização é que ele permite o resfriamento do ambiente, sem a necessidade de criar sombra, e, ao mesmo tempo, permite baixas temperaturas e fortes intensidades de luz, gerando no verão, boas condições para muitas espécies de plantas, tanto ornamentais como hortícolas.

Comparando a temperatura do ar externa e a interna, em ambientes protegidos similares, Montero \& Antón (1994), observaram que, em um dia de verão em Barcelona, Espanha, com umidade relativa de 59\%, ao meio-dia, a temperatura do ambiente com nebulização era de 2,0 a $3,0^{\circ} \mathrm{C}$ menor que a do ambiente externo, enquanto, no ambiente-controle, de aproximadamente $6,0^{\circ} \mathrm{C}$ acima da temperatura externa. O resfriamento por evaporação é o mais efetivo método para baixar a temperatura do ar, tanto em ambientes protegidos em áreas secas, como em áreas úmidas, durante as primeiras fases do desenvolvimento da cultura.

\subsection{Luminosidade}

De acordo com Bliska \& Honório (1996), a escolha do material de cobertura pode alterar a quantidade de luz transmitida ao interior de estufas, beneficiando as plantas, de acordo com suas exigências. Para Sentelhas et al. (1998), conforme o tipo do material de cobertura, a luminosidade é atenuada de forma diferenciada. Ao estudarem tal característica, verificaram que, para filmes de polietileno de baixa densidade (PEBD) e PVC, os valores de atenuação encontrados foram de 20 e 33\%, respectivamente.

De acordo com Farias et al. (1993), o material plástico mais empregado atualmente em cultivos protegidos é o polietileno de baixa densidade (PEBD), o qual apresenta boa transparência à radiação solar (onda curta), com 
transmissividade de 70 a $90 \%$ da radiação incidente, podendo atingir, entre as 14 e as 16 h, o máximo de 93 a $95 \%$.

Fugiwara (2000) realizou estudo, no qual foi analisada a influência da vida útil de 5 coberturas plásticas, o PVC e o polietileno, com diferentes idades de uso, na luminosidade interna dos ambientes protegidos. O autor concluiu que, de forma geral, as coberturas de polietileno de baixa densidade apresentaram uma intensidade luminosa maior que o PVC, visto que este material apresentou uma maior retenção de impurezas, implicando menores taxas de luminosidade interna.

Segundo Andriolo (2000), o primeiro elemento do ambiente a condicionar o processo de produção é a radiação solar, sendo essencial, para a primeira etapa da cadeia, que é a fixação de $\mathrm{CO}_{2}$. É o elemento para o qual as possibilidades de manejo são mais limitadas, pois a suplementação de luz, para fins de fotossíntese, somente é utilizada em casos especiais, como na produção de mudas e/ou de espécies de elevado valor comercial, como as flores. Quando a radiação solar é excessivamente elevada, o crescimento é afetado negativamente. Isso ocorre, principalmente, pela redução da fotossíntese e pelo aumento da respiração, embora outras reações de síntese também sejam afetadas. Considerando-se, de forma isolada, o manejo da radiação excessivamente elevada pode ser feito facilmente, mediante a modificação da transmissividade do material de cobertura do ambiente protegido. Isso pode ser obtido pelo uso de telas de sombreamento, de telas refletoras, ou mediante a pintura da superfície do material.

Para Cermeño (1994), a luminosidade possui importância decisiva em todos os processos vitais das plantas. Existem funções de grande importância, no desenvolvimento dos vegetais, que são influenciadas pela energia luminosa, tais como a fotossíntese, o fotoperiodismo, o crescimento dos tecidos, a floração, o amadurecimento dos frutos, entre outras.

Estudando o efeito da cobertura plástica sobre a radiação solar global no interior do ambiente, Farias et al. (1993), concluíram que a percentagem de 
radiação difusa foi, na maioria do tempo, superior no interior do ambiente, por ser multidirecional é mais efetiva na fotossíntese, pois aumenta a capacidade de captação pelo dossel das plantas, compensando, em parte, a opacidade do plástico àradiação solar global.

Dentre os métodos utilizados para a redução da temperatura interna de abrigos para cultivo protegido, o emprego de telas de sombreamento vem sendo indicado como uma das soluções de menor custo econômico. Entretanto, é importante que se estabeleçam níveis adequados de sombreamento, não prejudiciais ao desenvolvimento e à produção das culturas (Faria Junior et al., 2000).

O sombreamento com telas pretas de polipropileno reduz a luminosidade no interior dos ambientes protegidos, de forma a atenuar as altas temperaturas. Essa técnica apresenta o problema da diminuição da radiação solar, em detrimento da fotossíntese, bem como o do incremento da radiação na faixa do infravermelho, que chegaria em excesso até as plantas. Além disso, alguns tipos de sombreamento podem reduzir a taxa de renovação do ar do ambiente protegido, diminuindo, dessa forma, o efeito da redução da temperatura interna (Matallana Gonzalez \& Montero Camacho, 1993).

Os diferentes gêneros de bromélias requerem diferentes intensidades de luz para seu pleno desenvolvimento. As Aechmeas necessitam de nível médio de iluminação (500 a 1.000 lux), enquanto as Guzmanias, de um nível de iluminação mais baixo (300 a 500 lux) (Trotman, 1990; Kämpf, 2000).

Para Head (1997), a luminosidade ótima é o máximo de luz solar que a planta consegue receber, sem que provoque queimaduras ou perda de coloração das folhas. Nesse sentido, a luminosidade é um fator diretamente ligado àtemperatura e àventilação, quanto mais amena for a temperatura, mais luz a planta consegue receber sem danos. 


\subsection{Microclima no interior dos ambientes protegidos}

\subsubsection{Radiação solar}

A radiação solar incidente no interior de um ambiente protegido, coberto com plástico, é sempre menor que a que incide sobre uma superfície livre, devido à reflexão e à absorção pelo material da cobertura plástica Pezzopane (1994).

Seemann (1979) afirmou que a absorção depende da composição química e da espessura do material plástico, as quais, além de reduzir a densidade de fluxo da radiação solar, possuem efeito seletivo, isto é, permitem a passagem de certas faixas espectrais, e reduzem a transmitância de outras faixas de comprimento de onda. Já a reflexão é condicionada pelas características da superfície da cobertura e pelo ângulo de incidência da radiação solar.

Robledo \& Martin ${ }^{2}$, citados por Farias et al. (1993), comentaram que, de acordo com a coloração, a opacidade ou a transparência, os filmes plásticos diferem quanto à absorção, à reflexão e à transmissão das radiações de onda curta e longa; observaram também que, em determinadas condições de temperatura e de umidade do ar, no interior dos ambientes, ocorre a condensação de vapor d'água sobre a face interna da cobertura.

A aderência de gotas de água sobre o filme plástico reduz a transmissividade do material; sendo assim, a camada de água condensada na superfície inferior do filme de polietileno aumenta, consideravelmente, a interceptação de radiação de ondas longas. Como conseqüência, pode-se obter maior conservação de calor. Esta característica, embora vantajosa durante a noite, não é desejável durante o dia, por impedir a entrada de parte da radiação solar incidente, o que reduz a fotossíntese e afeta o crescimento e o desenvolvimento das culturas (Tanaka \& Genta, 1982)

${ }^{2}$ ROBLEDO, F.P.; MARTIN, L.V. Aplicatión de los plásticos en la agricultura. Madrid: Mundi-Prensa, 1981, 552p. 
As informações sobre as características dos filmes plásticos, utilizados na agricultura, são de responsabilidade dos fabricantes. Estes devem informar sobre seus filmes plásticos, de modo que o técnico, o agrônomo e o produtor rural possam eleger os materiais e as marcas pela qualidade da luz que os filmes transmitem (Furlan, 2001).

\subsubsection{Temperatura do ar}

A temperatura do ar, no interior dos ambientes protegidos, está intimamente ligada ao balanço de energia, que irá depender de fatores como tamanho da estufa, propriedades óticas da cobertura e condições meteorológicas locais Buriol et al. (1993).

As características que afetam os processos de ganho e de perda de energia, como volume de ar do ambiente protegido, condições atmosféricas externas, área da superfície, transmissividade da cobertura, área de abertura, ventilação e cobertura do solo, condicionarão a temperatura nesses ambientes (Atarassi, 2000). Durante o dia, devido ao saldo positivo de radiação, a superfície aquece a parcela de ar próxima a ela, desencadeando um processo convectivo. Dentro do ambiente, esse processo é interrompido pela cobertura plástica, que impede a ascensão do ar quente, o que provoca a elevação das temperaturas durante o período diurno (Pezzopane, 1994). Com isso, as temperaturas máximas internas atingem valores bem mais elevados que as do ambiente externo.

Martins \& Gonzalez (1995) afirmaram que, quando esse incremento de temperatura no interior do ambiente atinge níveis muito elevados, tal efeito pode ser minimizado com a abertura lateral ou superior do ambiente, ou com o uso de um sistema de ventilação.

Camacho et al. (1995), em trabalho realizado em Pelotas, RS, observaram que as temperaturas mínimas do ar, em ambientes com PEBD, eram inferiores às do exterior, durante o período de junho a meados da 
primavera. O fenômeno, denominado de "inversão térmica", ocorre devido àalta transmissividade do PEBD à radiação de onda longa (infravermelho), o que permite grande perda de energia durante o período noturno. A redução da temperatura ainda é auxiliada pela falta de movimentos verticais e horizontais de massas de ar, no interior do ambiente, que, em condições de céu aberto, transportariam energia entre as camadas, reduzindo o resfriamento contínuo.

Reis (1997) relatou que, em Brasília, DF, uma estufa do modelo teto em arco, coberto com filme PEBD de $150 \mu$, apresentou ganho de temperatura, com relação ao meio externo, de até $8,7^{\circ} \mathrm{C}$ (às $14 \mathrm{~h}$ ) e que permaneceu maior que $7^{\circ} \mathrm{C}$ até æ̀s $2 \mathrm{~h}$ da manhã, diminuindo gradativamente até æ̀s $8 \mathrm{~h}$, quando foi observada a menor diferença $\left(4,7^{\circ} \mathrm{C}\right)$. Folegatti et al. (1997) observaram que, na primavera, os valores das temperaturas máxima, média e mínima do ar, dentro do ambiente, foram sempre superiores aos do exterior (14,8\%; $8,5 \%$ e $5,9 \%$, respectivamente), com menor valor das mínimas de $12,2^{\circ} \mathrm{C}$ e o maior valor das máximas de $42,2^{\circ} \mathrm{C}$.

\subsubsection{Umidade relativa do ar}

A umidade relativa do ar, no interior de um ambiente protegido, é determinada diretamente pela temperatura, numa relação inversa entre ambas: diminui durante o dia e aumenta durante a noite, no período de $24 \mathrm{~h}$, podendo variar de 30 a 100\%, dependendo logicamente, das condições climáticas da região, conforme Lorenzo Mínguez ${ }^{3}$ citado por Martins et al. (1999).

A umidade relativa do ar influencia a transpiração, o crescimento, a fecundação das flores e a ocorrência de doenças (Cermeño, 1994). Furlan (2001) comenta que altos valores de umidade relativa do ar reduzem a taxa de evapotranspiração da cultura e que, quando associados a altas temperaturas do ar geram também condições muito favoráveis à ocorrência de doenças. Já valores muito baixos de umidade relativa também podem provocar altas taxas

${ }^{3}$ LORENZO MÍNGUEZ, P. Los determinantes microclimáticos de la horticultura intensiva en el sur mediterráneo. In: Tecnologia de invernaderos II. Almeria: FIAPA, 1998. p.25-44. 
de evapotranspiração, o que pode reduzir a taxa fotossintética e, conseqüentemente, a produção da cultura.

Segundo Baêta \& Souza (1997), em ambientes protegidos as plantas cresceriam melhor quando expostas a alta umidade (70 a 80\%) porque, assim, o estresse evaporativo seria reduzido.

Farias et al. (1992) estudaram, na região Sul do Brasil, a variação dos elementos meteorológicos no interior de ambientes com cobertura plástica; encontraram, em relação ao meio externo, valores de umidade relativa máxima mais elevados no período noturno, em razão da maior concentração de vapor de água no interior do ambiente e dos valores de umidade relativa. Atribuíram tal resultado ao fato de as cortinas estarem abertas, não retendo, portanto, o vapor, e por estar a temperatura do ar mais elevada sob a cobertura plástica.

Em experimento conduzido em ambiente protegido, com feijão-devagem, Farias et al. (1992), relataram que, no início do experimento, quando a cultura estava pouco desenvolvida, os valores internos de umidade relativa do ar foram inferiores aos observados externamente, ocorrendo, em seguida, um período de equilíbrio entre os dois ambientes. Após o sétimo decêndio, os valores internos mostraram-se superiores aos observados externamente. Nesse período, a cultura, já bastante desenvolvida, liberou maior volume de água pela transpiração e, também, pela maior freqüência de irrigação (devido ao maior consumo de água pela cultura). O fato provocou o aumento da pressão de vapor de água e, conseqüentemente, da umidade relativa do ar no interior do ambiente, acentuada pela pequena renovação da massa de ar .

Pezzopane (1994) obteve, em seu experimento, em um dia que houve manejo de cortina, valores similares de umidade relativa do ar, dentro e fora da estufa plástica coberta com PEBD, e verificou que, quando a cortina permaneceu fechada, houve muita diferença entre a umidade dentro e fora da estufa, devido à não-renovação de ar. Com a abertura das cortinas laterais, a umidade caiu rapidamente, ficando próxima aos valores observados 
externamente, voltando a elevar-se com o fechamento das cortinas, a partir das $17 \mathrm{~h}$.

2.7.4 Temperatura de globo negro e carga térmica radiante

A temperatura indicada pelo globo provê uma estimativa dos efeitos combinados da energia térmica radiante, procedente do meio ambiente em todas as direções, da temperatura do ar, associada aos efeitos convectivos, relacionados com a velocidade do vento. Segundo Silva (2000), um dos melhores instrumentos para a determinação da carga térmica radiante (CTR) é o globo de Vernon, também conhecido como globo negro.

A leitura é expressa em termos de temperatura de globo negro (TGN), em graus Celsius, e provê uma medida indireta do calor radiante do ambiente (Baccari Júnior, 1998). Quando a energia solar incide sobre a cobertura, ela é refletida, absorvida ou transmitida, em quantidades que dependem das propriedades físicas dos materiais que a compõem. A quantidade de energia radiante absorvida, proveniente da cobertura, pode ser determinada através da carga térmica de radiação (CTR), que expressa a radiação total recebida pelo globo negro, de todos os espaços ou vizinhanças, influenciada por fatores tais como, orientação, altura do ambiente, composição (Bond et al., 1955).

Em estudo realizado por Nascimento e Silva (1999) em ambientes protegidos com alturas de 3,0 e 3,5m, foi observado que valores de temperatura de globo negro e carga térmica de radiação não sofreram influência da elevação do pé direito; os valores encontrados não foram significativos nos horários estudados $(8,10,12,14,16$ e 18h). 


\section{MATERIAL E MÉTODOS}

\subsection{Localização do experimento}

O experimento foi conduzido no período de 26/03/2001 a 03/04/2002, totalizando 000 dias, em dois ambientes protegidos, na área experimental do Núcleo de Pesquisa em Ambiência (NUPEA), junto ao Departamento de Engenharia Rural, da Escola Superior de Agricultura "Luiz de Queiroz", da Universidade de São Paulo (ESALQ/USP), situada no município de Piracicaba, SP.

As coordenadas geográficas são: latitude $22^{\circ} 42^{\prime} 40$ ”'S, longitude 473' $30^{\prime \prime} \mathrm{W}$ e altitude de $570 \mathrm{~m}$.

Segundo a classificação climática de Köppen, Piracicaba possui clima Cwa, ou seja, subtropical úmido, com estiagem no inverno.

\subsection{Instalação do experimento}

O trabalho foi desenvolvido de acordo com o fluxograma representado nas Figuras 02 e 03. 


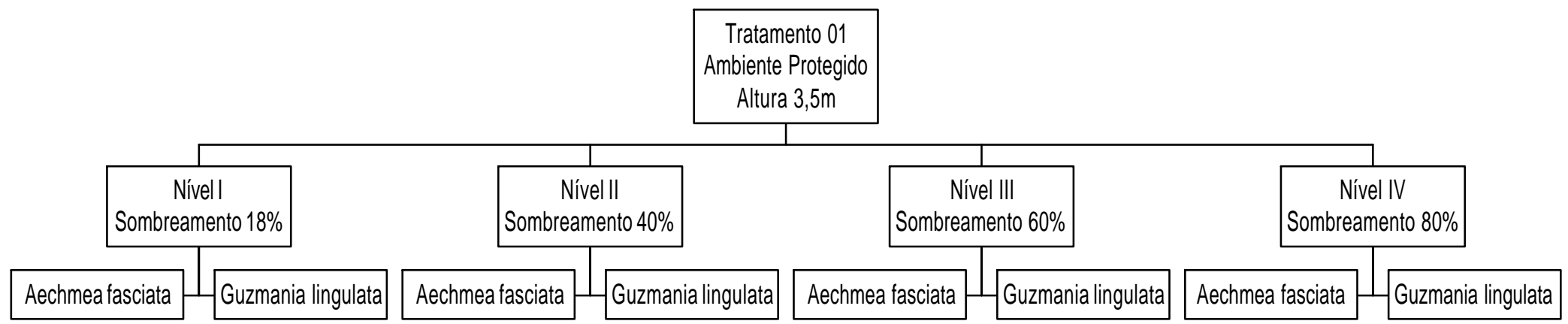

Figura 2 - Organograma referente ao ambiente protegido com altura de 3,5m.

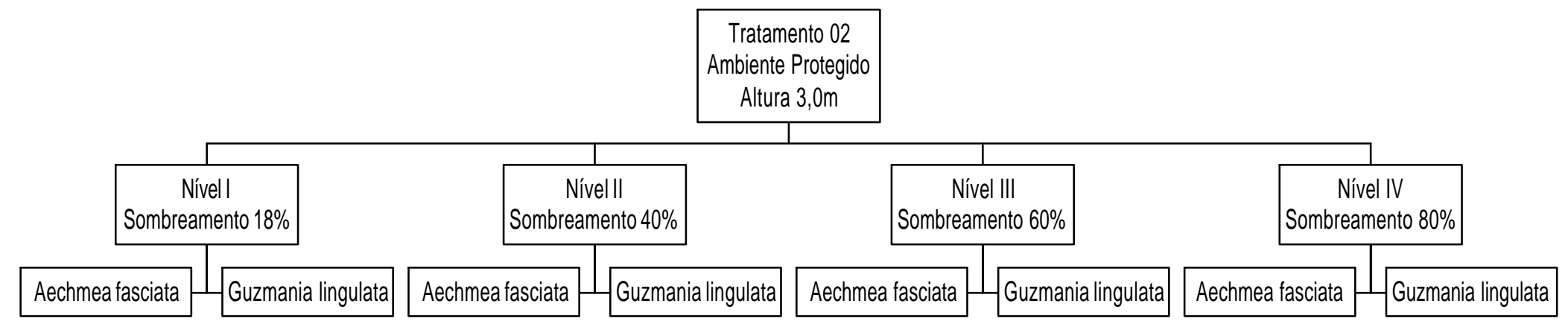

Figura 3 - Organograma referente ao ambiente protegido com altura de 3,0m. 


\subsubsection{Ambientes protegidos}

Em função do esquema experimental, foram utilizados dois ambientes protegidos, modelo arco Pampeana, pré-fabricados em ferro galvanizado, com as seguintes dimensões: $17,5 \mathrm{~m}$ de comprimento, $6,4 \mathrm{~m}$ de largura como medidas internas, e alturas de $3,0 \mathrm{~m}$ e $3,5 \mathrm{~m}$, ambas orientadas no sentido lesteoeste, cada uma com área total de $112,0 \mathrm{~m}^{2}$. A cobertura dos ambientes protegidos e o fechamento das laterais foram de polietileno de baixa densidade (PEBD), com espessura de $150 \mu$. As laterais dos ambientes foram dotadas de sistemas de manivelas, que permitia o manejo das cortinas, as quais eram abertas às 8 e fechadas æ̀s 18 h (Figura 4).

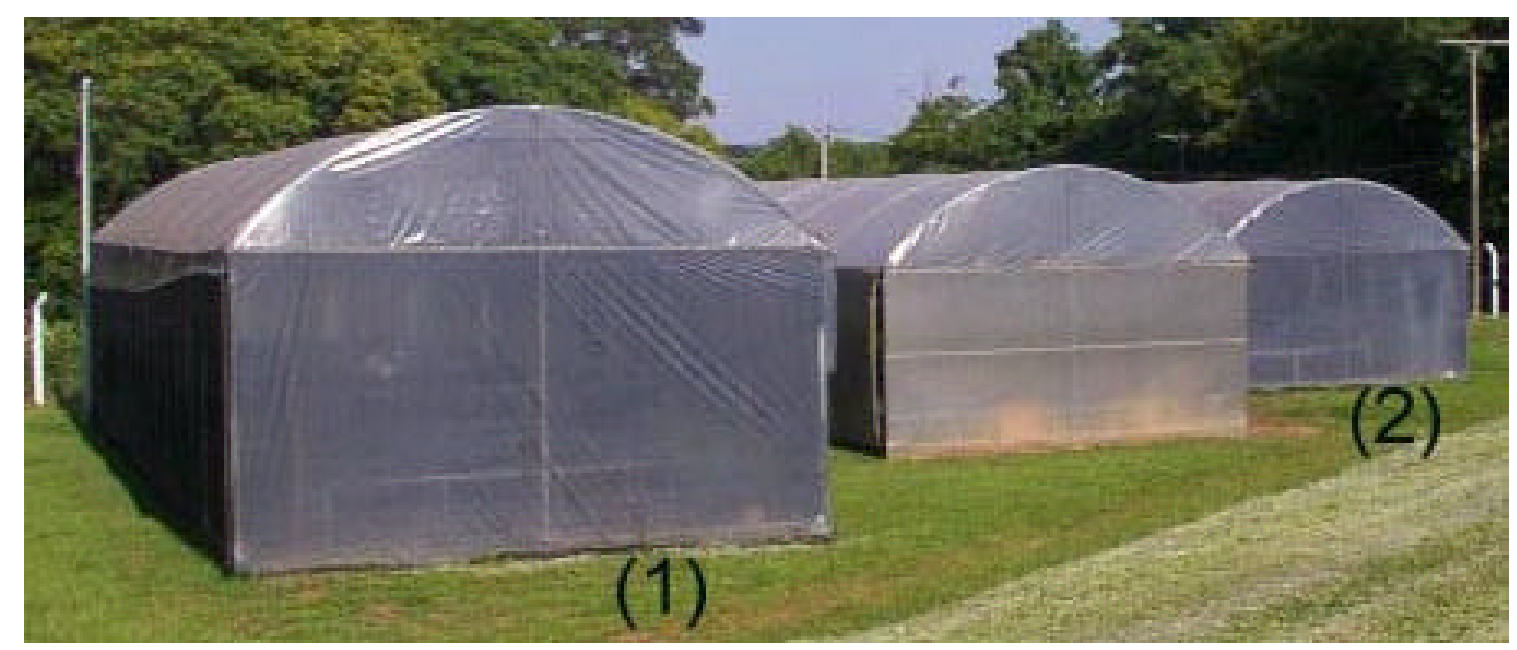

Figura 4 - Vista dos ambientes protegidos (1 e 2), com 3,5 e 3,0m de altura respectivamente, utilizados na condução do experimento, no NUPEA/ESALQ/USP, em Piracicaba, SP.

\subsubsection{Bancadas de cultivo e sistema de sombreamento}

No interior de cada ambiente protegido, foram colocadas 8 bancadas de cultivo, com as seguintes dimensões: $4 \mathrm{~m}$ de comprimento por $1 \mathrm{~m}$ de largura e 
0,80m de altura. Cada uma delas possuía 20 plantas, sendo utilizadas somente 10 vasos, para a coleta de dados referente ao crescimento.

A Figura 5 mostra o esquema da disposição aleatória dos tratamentos, no interior dos ambientes.

Espécie 1: Guzmania lingulata

Espécie 2: Aechmea fasciata

Estufa 3,5m

Espécie 1

Espécie 2

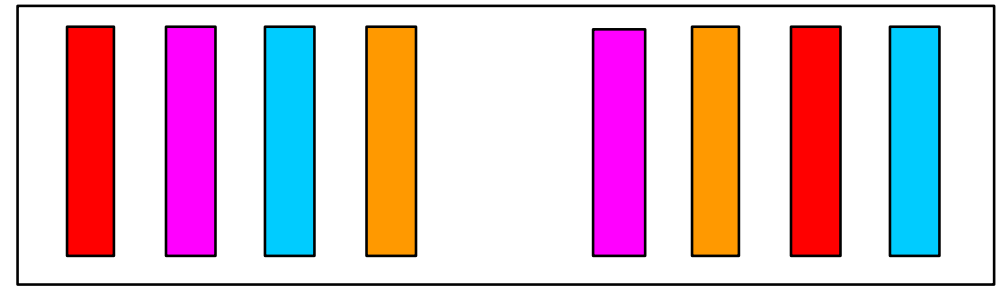

$18 \%$

$40 \%$

$60 \%$

$80 \%$

Estufa 3,0m

Espécie 2

Espécie 1

एक $\square \square \square \square$

Figura 5 - Desenho esquemático da distribuição dos tratamentos, no interior dos ambientes protegidos com diferentes alturas.

O sistema de sombreamento foi montado com o auxílio de uma estrutura de arame, fixada à altura de 1,0m acima da superfície de cada bancada. As telas de sombreamento foram fixadas aos arames, cobrindo todos os lados da bancada (parte superior e laterais), conforme mostra a Figura 6. 


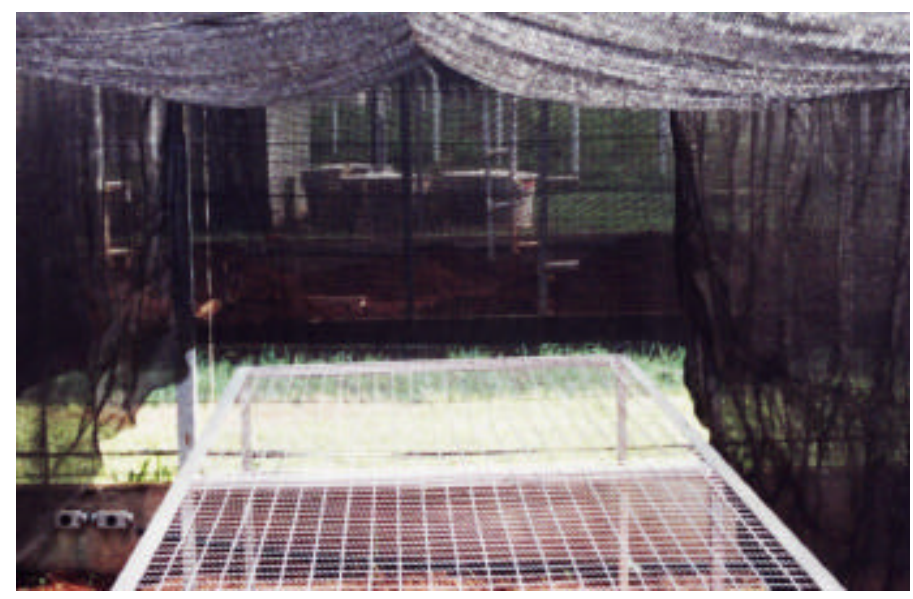

Figura 6 - Vista de uma das bancadas de cultivo, com a estrutura de sombreamento com tela de $40 \%$, fixada acima da sua superfície.

Procurando estudar a resposta das diferentes espécies de bromélias ao melhor nível de sombreamento, foram utilizadas diferentes telas, ou malhas (Figura 7), comercializadas como Sombrites ${ }^{\circledR}$. As telas utilizadas possuem as seguintes percentagens de sombreamento: 18, 40, 60 e $80 \%$.

$(18 \%)$

$(40 \%)$
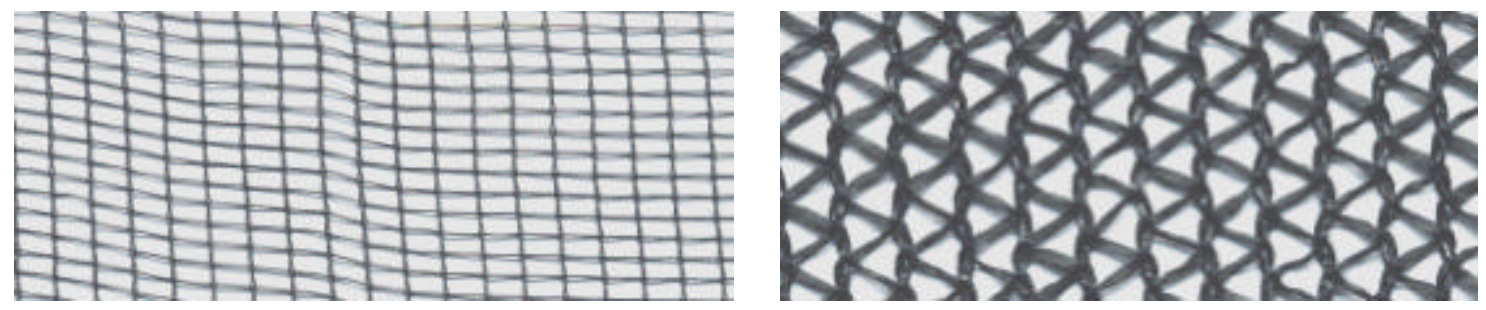

$(60 \%)$

$(80 \%)$
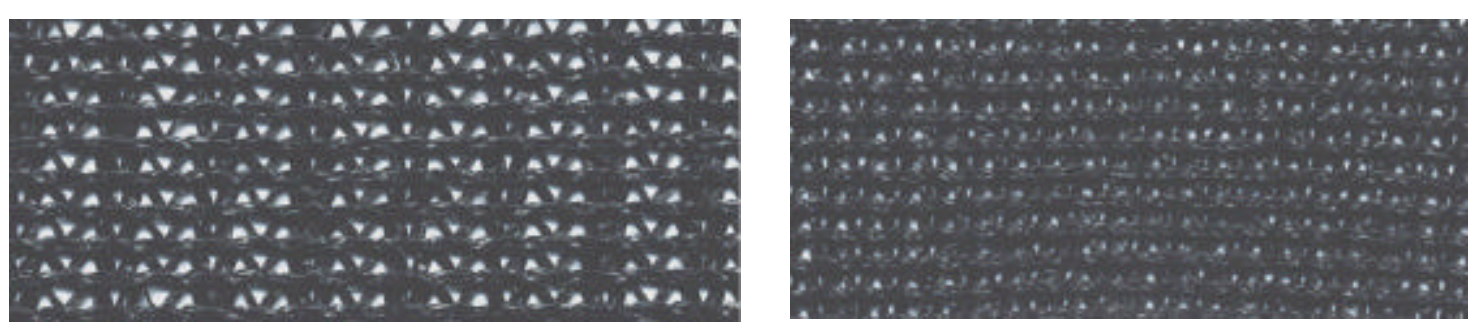

Figura 7 - Telas com diferentes percentagens de de sombreamento, utilizadas no experimento. 


\subsubsection{Material vegetal}

As mudas de $A$. fasciata e $G$. lingulata utilizadas no experimento foram obtidas a partir de cultura de meristemas no laboratório de micropropagação da empresa "Bromélias Rio", especializada na produção de bromélias, sediada em Campinas, SP (Figura 8).

(a)
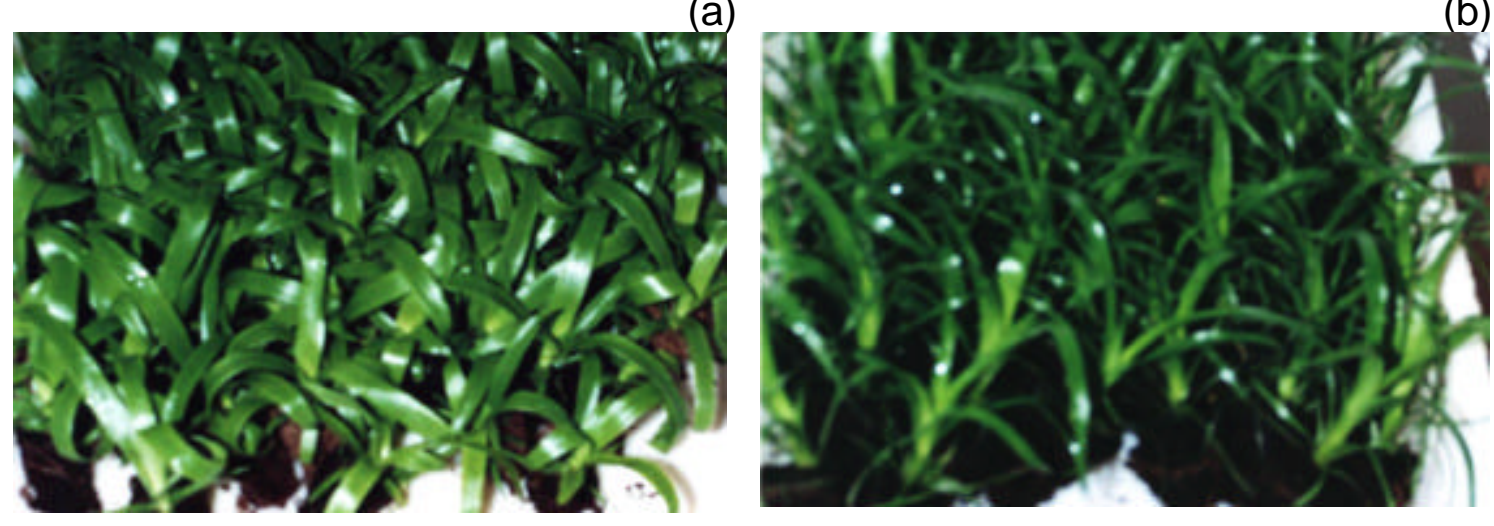

Figura 8 - Mudas de A. fasciata (a) e G. lingulata (b), utilizadas na condução do experimento.

As primeiras avaliações vegetativas foram realizadas quando da chegada das plantas ao Departamento, com idade "aproximada" de 90 dias. As medidas foram feitas em 50 plantas de cada uma das espécies. As médias são apresentadas na Tabela 2, de acordo com as medições realizadas:

Tabela 2 - Médias referentes às medidas realizadas nas mudas de bromélias, no início do experimento.

\begin{tabular}{lcc}
\hline & \multicolumn{3}{c}{ Espécies } \\
Medidas da parte aérea & A. fasciata & G. lingulata \\
\hline Altura da planta $(\mathrm{cm})$ & 5,0 & 6,5 \\
Número de folhas & 7,1 & 6,3 \\
Maior largura da folha $(\mathrm{cm})$ & 1,0 & 0,9 \\
Diâmetro da roseta $(\mathrm{cm})$ & 19,9 & 22,1 \\
\hline
\end{tabular}




\subsubsection{Recipientes para o cultivo}

$O$ experimento foi dividido em duas fases, de acordo com 0 desenvolvimento das plantas, e foram utilizados dois tamanhos de vasos (Figura 9).

- Primeira fase: 5 primeiros meses após o transplantio. Foram utilizados vasos plásticos de cor preta, com diâmetro, na parte superior, de $10 \mathrm{~cm}$ (vaso $\mathrm{r}^{\mathrm{P}}$ 10) e, na inferior, de $7,5 \mathrm{~cm}$, com altura de $7,5 \mathrm{~cm}$, providos de 5 orifícios de drenagem na parte inferior. Os vasos tiveram o seu fundo preenchido com $2,0 \mathrm{~cm}$ de pedras britadas, para facilitar a drenagem e para proporcionar uma maior estabilidade vertical;

- Segunda fase: após os 5 meses do início do experimento, as plantas foram transferidas para os vasos definitivos, também de cor preta, e com diâmetro na parte superior, de $15 \mathrm{~cm}$ (vaso $\mathrm{n}^{0} 15$ ) e, na inferior, de 10,5cm, com altura de $12,5 \mathrm{~cm}$, providos de 9 orifícios de drenagem na parte inferior. Os vasos tiveram o fundo preenchido com $2,0 \mathrm{~cm}$ de pedras britadas, para facilitar a drenagem e para proporcionar uma maior estabilidade vertical.

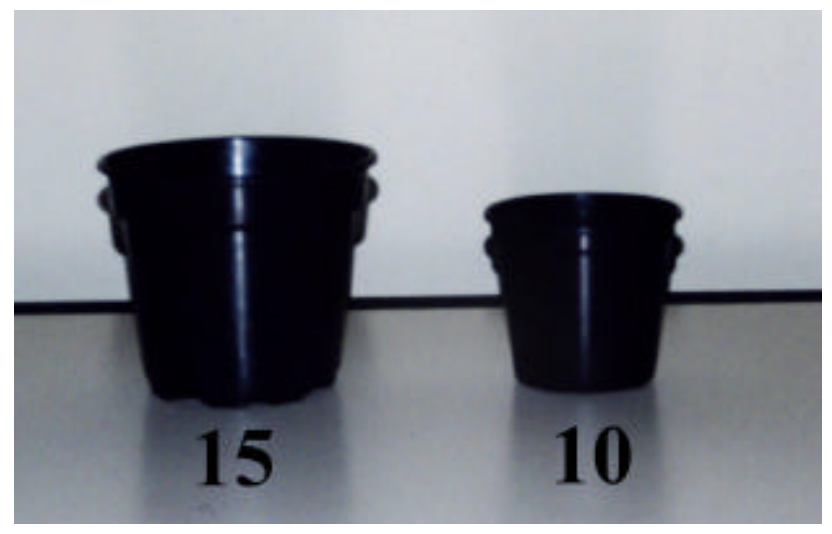

Figura 9 - Vasos de 15 e 10cm de diâmetro, na parte superior, utilizados no experimento para o acondicionamento das mudas de bromélias. 


\subsubsection{Substrato}

O substrato utilizado para o acondicionamento das mudas nos vasos possuía uma composição de $65 \%$ de casca de Pinus, com diâmetro de $12 \mathrm{~mm}$, $35 \%$ de xaxim compostado, enriquecido com super fosfato simples purificado, nitrato de cálcio e MAP (monoamônio fosfato) granulado.

\subsubsection{Espaçamento entre os vasos}

Os vasos com as plantas de bromélias foram dispostos sobre as bancadas de cultivo, com espaçamento de $20 \times 20 \mathrm{~cm}$. Este espaçamento foi alterado para $30 \times 30 \mathrm{~cm}$, após o transplantio para os vasos de maior diâmetro ( $\mathrm{n}^{0}$ 15), evitando, assim, a competição entre as plantas.

Após realizadas as primeiras medidas, as plantas foram transplantadas das bandejas de cultivo para os vasos, e submetidas aos diferentes níveis de sombreamento. Os vasos com as mudas de bromélias foram dispostos sobre as bancadas de cultivo, 20 vasos por bancada, totalizando 320 vasos nos dois ambientes. Para a tomada de medidas da parte aérea, foram escolhidas, ao acaso, 10 plantas por tratamento/bancada (Figura 10).

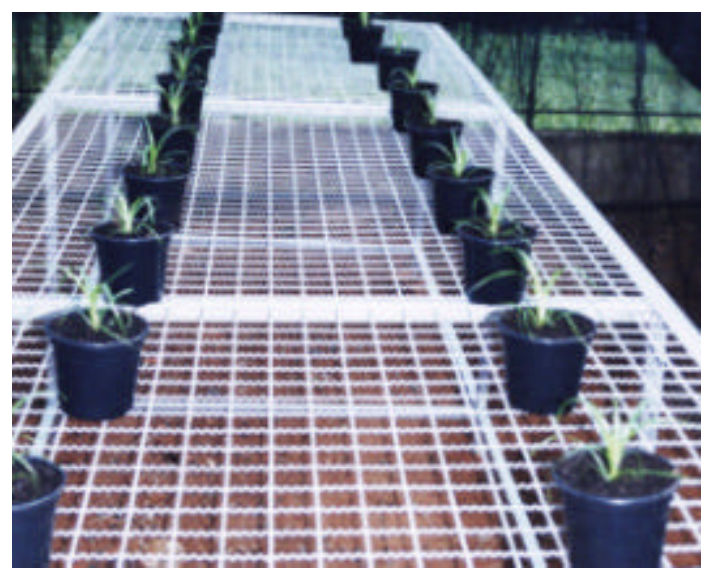

Figura 10 - Vista de uma das bancadas de cultivo, com as mudas de $G$. lingulata transplantadas para os vasos $n . .-10$, localizada no interior do ambiente protegido com altura de $3,5 \mathrm{~m}$. 


\subsubsection{Adubações}

As adubações, realizadas semanalmente, consistiam de aplicações na parte aérea (foliar) e no substrato (radicular). A solução preparada foi aplicada com o auxílio de pulverizador, com capacidade de $4 \mathrm{~L}$, enquanto as adubações no substrato foram realizadas manualmente, utilizando-se o adubo líquido, marca Fertamim-M® $(0,5 \mathrm{~L} / 100 \mathrm{~L})$. Cada vaso recebeu $200 \mathrm{ml} / \mathrm{semana}$ da solução.

Na primeira fase do experimento, quando as plantas se encontravam nos vasos de $n^{\circ} 10$, foram aplicados, ao substrato, $50 \mathrm{ml}$ da solução, por planta. Após o transplantio para os vasos de $n^{0} 15$, a quantidade da solução aplicada ao substrato foi aumentada para $150 \mathrm{ml}$ da solução, por vaso.

\subsubsection{Sistema de irrigação e de nebulização}

Os sistemas foram compostos por uma bomba $\mathrm{KSB}{ }^{\circledR}$, de $1 \mathrm{cv}$, com sistema de filtragem da água, cuja parte elétrica é composta por chave de partida rápida Siemens ${ }^{\circledR}$, com três posições. Para o controle do acionamento das válvulas do sistema de irrigação e de nebulização foi instalado um painel controlador automático marca Galcon®.

O painel permitiu fazer a programação dos horários e dos intervalos de acionamento de ambos os sistemas. (Figuras 11a e 11b). Foram utilizadas três caixas d' água, com capacidade de $500 \mathrm{~L}$ cada, para suprir as necessidades hídricas dos dois ambientes protegidos. 
(a)

(b)
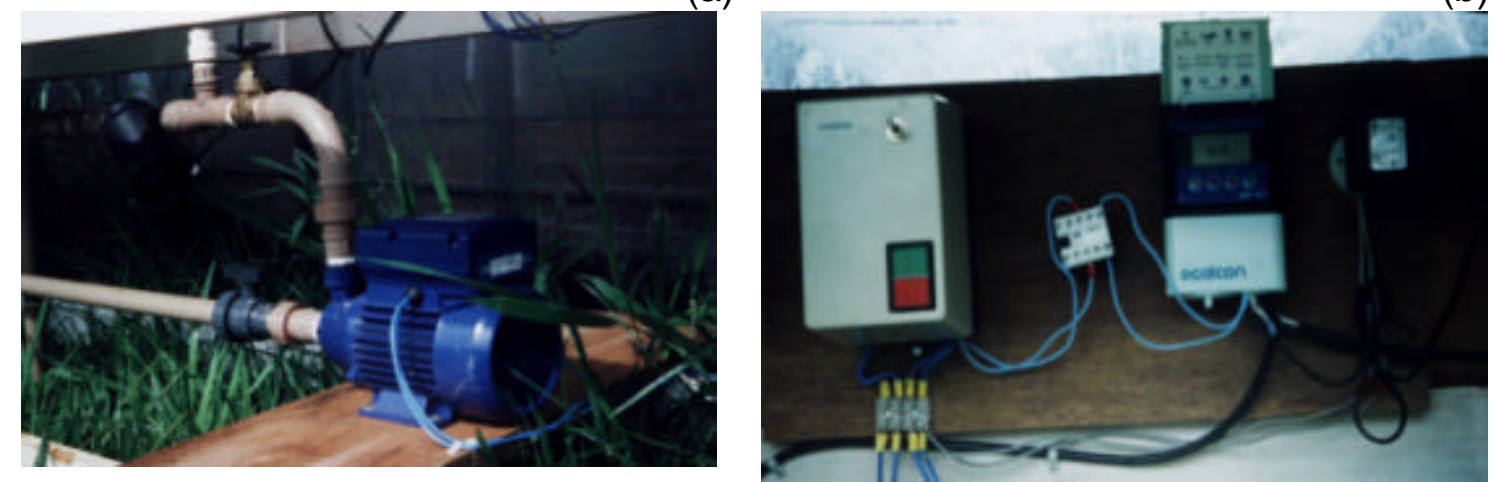

Figura 11 - Bomba KSB, com sistema de filtragem de água (a) e painel de acionamento do sistema de irrigação e de nebulização (b), situados na área experimental do NUPEA/ESALQ/USP, em Piracicaba, SP.

\subsubsection{Irrigação das plantas}

O sistema de irrigação foi composto por duas linhas de microaspersores, com sistema antigotejo, marca $\mathrm{DAN} \AA$, instalados sob as telas de sombreamento, á altura aproximada de 1,0m da superfície das bancadas. Cada bancada possuiu dois microaspersores cada um com vazão de $104 \mathrm{~L} / \mathrm{h}$ (Figura 12).

O acionamento do sistema foi controlado automaticamente pelo painel Galcon $\AA$, a irrigação foi realizada a cada 2 dias, ficando o sistema ligado por 15min. Este intervalo foi definido de acordo com a umidade dos vasos. 


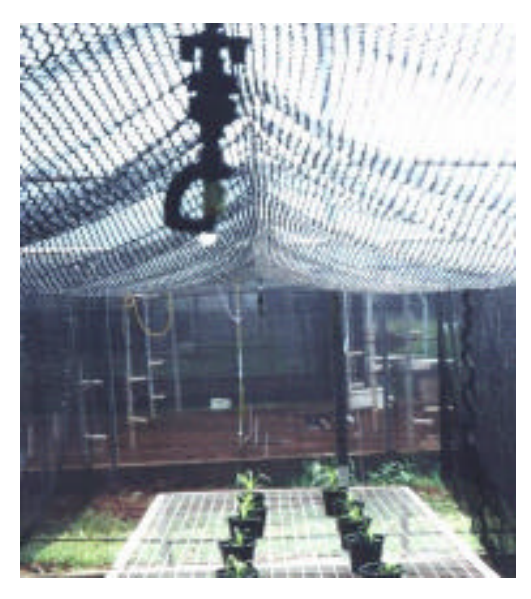

Figura 12 - Microaspersor sob a tela de sombreamento de 18\%, que promoveu a irrigação das plantas sobre a bancada de cultivo.

\subsubsection{Nebulização do ambiente}

O sistema de nebulização tem, como finalidade, reduzir a temperatura do ambiente de forma uniforme. Foi constituído por duas linhas com 34 bocais (0,50m de espaçamento entre cada bocal), instalados a uma altura de $3 \mathrm{~m}$ do nível do solo. O modelo utilizado foi DAN FOGGER®, com vazão de $7 \mathrm{~L} / \mathrm{h}$.

Seu acionamento foi realizado pelo painel de controle Galcon $\AA$, programado para funcionamento diário no período das 10 às $18 \mathrm{~h}$, com intervalos de acionamento de $4 \mathrm{~min}$, permanecendo acionado por cerca de 15seg (Figura 13).

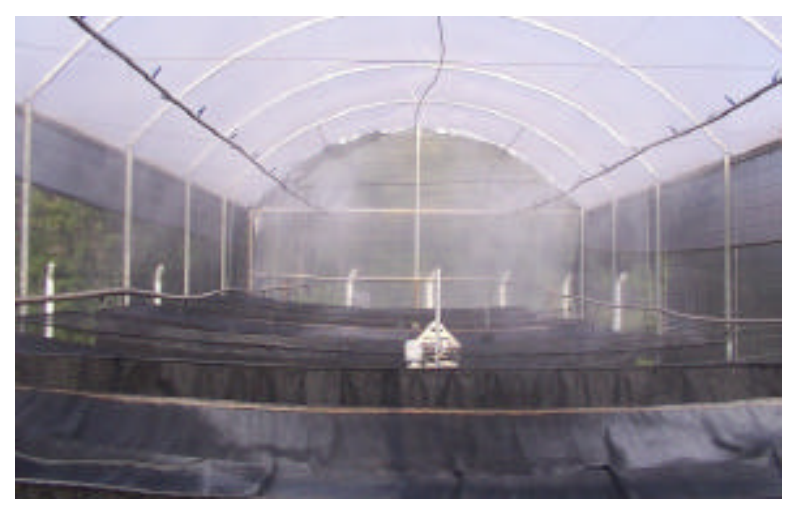

Figura 13 - Vista do ambiente protegido com altura de 3,5m, com o sistema de nebulização acionado. 


\subsubsection{Controle de pragas e de doenças}

Apesar de as bromélias serem plantas rústicas e resistentes, não estão livres dos ataques de pragas e de doenças, tais como lagartas, bacterioses e fungos. Logo no início do experimento, foi constatado o aparecimento de lagartas, controladas com a pulverização do inseticida clorpirifós $0,1 \%$. Para o controle da fusariose, foram realizadas aplicações semanais com o fungicida benomil $(5 \mathrm{gr} / \mathrm{L})$; as aplicações na parte aérea foram realizadas com um pulverizador. Foi realizada, também, a aplicação do mesmo fungicida diretamente no substrato, nas mesmas proporções de diluição, sendo colocados, em cada vaso $200 \mathrm{ml}$.

\subsection{Coleta de dados}

\subsubsection{Dados micrometeorológicos}

Os dados foram coletados durante o período diurno (æ̀ 8, 10, 12, 14, 16 e $18 \mathrm{~h}$ ), no período de $26 / 04 / 2001$ a $25 / 02 / 2002$, tanto no ambiente externo, quanto no interior dos ambientes protegidos.

\subsubsection{Coleta automatizada}

Foi instalado, no interior dos ambientes protegidos e fora deles um sistema de aquisição de dados automatizado, marca Squitter ${ }^{\circledR}$, modelo A 1000 (Figura 14a e 14b); programou-se que as coletas seriam descarregadas a cada 15min e armazenadas em um datalloger. Foram coletadas, através dos sensores, a temperatura do ar, a umidade relativa do ar e a radiação solar.

As estações meteorológicas foram instaladas no centro dos ambientes protegidos, àaltura de $1,70 \mathrm{~m}$ do solo. 
(a)

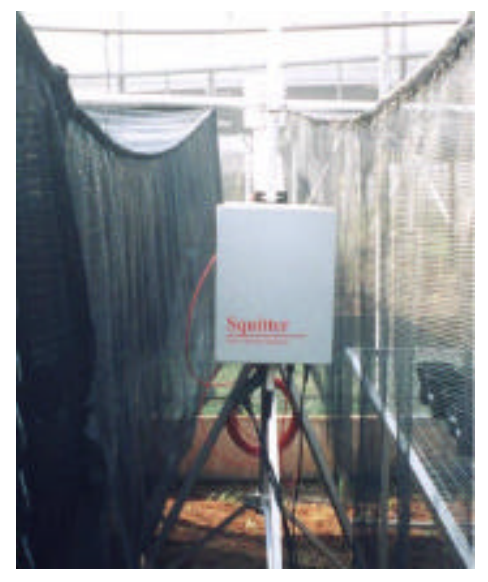

(b)

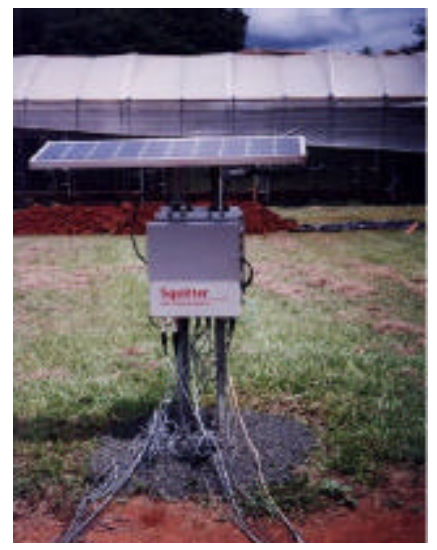

Figura 14 - Sistemas automáticos de aquisição de dados, usados na coleta de dados tanto no interior dos ambientes protegidos (a), quanto no exterior (b).

\subsubsection{Coleta manual}

Foram coletados, nos ambientes internos e externo, dados de temperatura de globo negro, de intensidade luminosa e de velocidade do vento.

No interior das bancadas, sob as telas de sombreamento, foram coletados dados de temperatura de bulbo seco e de bulbo úmido, de temperatura de globo negro e de intensidade luminosa.

Todos os dados coletados foram registrados às $8,10,12,14,16$ e 18h.

a) Temperatura de globo negro (TGN) e carga térmica radiante (CTR)

O termômetro de globo negro foi localizado no centro dos dois ambientes em estudo, àuma altura de $1,70 \mathrm{~m}$ da superfície do solo (Figura 15a), sua leitura é realizada pela leitura direta no termômetro, sendo esta em graus Celsius. Através do termômetro de globo negro é possível calcular a carga térmica radiante que chega ao ambiente. 
A Carga Térmica Radiante (CTR), proposta por Esmay (1979), pode ser calculada pelas equações:

$\mathrm{CTR}=\delta(\mathrm{TRM})^{4}$

$\mathrm{TRM}=100\left\{2,51 \times \mathrm{VV}^{0,5}\left((\operatorname{tg}+273)-(\operatorname{tbs}+273)+((\operatorname{tg}+273) / 100)^{4}\right)\right\}^{0,25}$

onde,

$\delta=$ constante de Stefan-Boltzmann $\left(5,67 \times 10^{-8} \mathrm{~K}^{4} \times \mathrm{W} / \mathrm{m}^{2}\right)$;

$\mathrm{TRM}=$ temperatura radiante média, $\left(\mathrm{K}^{\circ}\right)$;

$\mathrm{V} v$ = velocidade do vento $(\mathrm{m} / \mathrm{s})$;

$\mathrm{tg}=$ temperatura de globo negro $\left({ }^{\circ} \mathrm{C}\right) \mathrm{e}$

tbs $=$ temperatura de bulbo seco $\left({ }^{\circ} \mathrm{C}\right)$.

b) Intensidade luminosa

As medidas da intensidade luminosa, no interior dos dois ambientes e dentro de cada estrutura sombreada, foram obtidas com o auxílio de um luxímetro digital, marca Minipa® (Figura 15b).

As medidas realizadas no interior dos ambientes foram feitas no centro dos mesmos à altura de $1,70 \mathrm{~m}$ do solo; já as medidas realizadas sob as telas de sombreamento foram feitas no centro das bancadas, na mesma altura em que se encontravam as plantas. As medidas do nível de lux, realizadas com o aparelho, estão na faixa de 0,1 lux a 200.000 lux. 
(a)
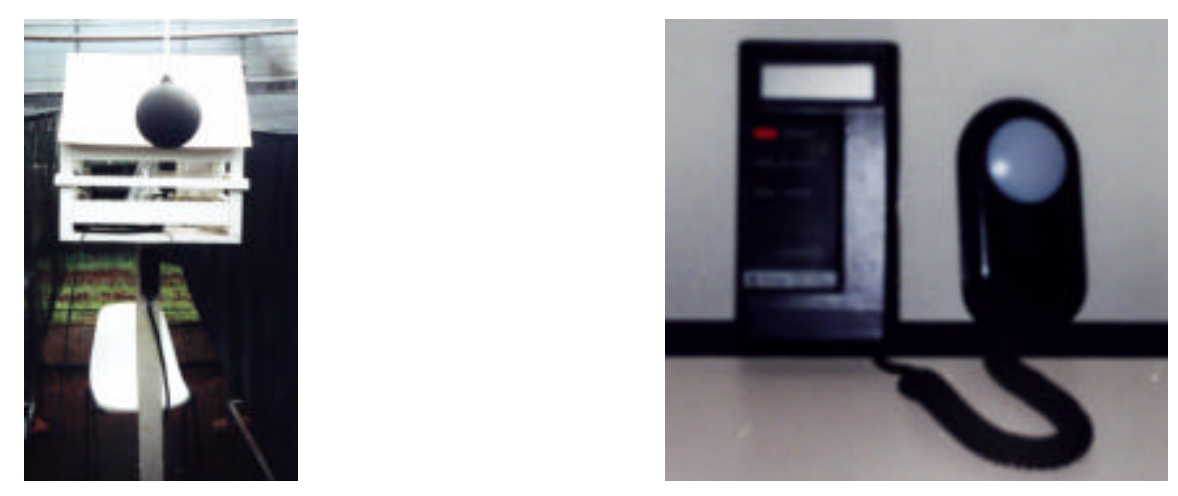

Figura 15 - Termômetro de globo negro (a) e luxímetro digital (b), utilizados para a coleta de dados de temperatura de globo negro $\left({ }^{\circ} \mathrm{C}\right)$ e de intensidade luminosa (lux).

c) Velocidade do vento

As medidas referentes à velocidade do vento, em $\mathrm{m} / \mathrm{s}$, foram realizadas com o auxílio de um anemômetro digital, marca Testo®; foram coletadas no centro dos ambientes àaltura de $1,70 \mathrm{~m}$, e fora dos ambientes protegidos.

d) Temperatura e umidade do ar sob as telas de sombreamento

Foram realizadas, sob as telas de sombreamento, medidas de temperatura de bulbo seco e de bulbo úmido, através de higrômetro de leitura direta, com escala graduada em ${ }^{\circ} \mathrm{C}$, marca Incoterm ${ }^{\circledR}$. Os higrômetros encontravam-se sob as bancadas de cultivo, situados no centro, à uma altura de $0,80 \mathrm{~m}$ da superfície das mesmas.

A umidade relativa do ar, no interior das bancadas foi calculada pelas equações descritas abaixo:

$$
\begin{aligned}
& \text { UR }=\text { ea/es * } 100(\%), \\
& \text { ea }=\text { esu }-A \text { * Patm * (Ts }-T u),
\end{aligned}
$$


esu $=0,6108 * 10^{\left(7,5^{*} \mathrm{Tu} / 237,3+\mathrm{Tu}\right)}$,

es $=0,6108^{*} 10^{\left(7,5^{*} \mathrm{Ts} / 237,3+\mathrm{Ts}\right)}$,

onde,

$\mathrm{UR}=$ umidade relativa (\%),

ea $=$ pressão atual de vapor $(\mathrm{kPa})$,

es $=$ pressão de saturação $(\mathrm{kPa})$,

esu = pressão de saturação, calculada através da temperatura de bulbo úmido $(\mathrm{kPa})$,

Ts = temperatura de bulbo seco $\left({ }^{\circ} \mathrm{C}\right)$,

$\mathrm{Tu}=$ temperatura de bulbo úmido $(\stackrel{\circ}{\mathrm{C}})$,

$A=$ constante do psicrômetro não ventilado $\left(0,0008{ }^{\circ} C^{-1}\right)$,

Patm = pressão atmosférica do local $(95 \mathrm{kPa})$.

\subsubsection{Dados da planta}

Foram realizadas as seguintes medidas da parte vegetativa das plantas, de acordo com a metodologia adotada por Kanashiro (1999): altura das plantas, número de folhas, folha com maior largura e maior diâmetro da roseta.

As medidas da parte vegetativa apresentadas foram realizadas ao longo do ciclo da planta, aos $20,65,110,155,200,245,290,335$ e 380 dias após o transplantio das mudas para os vasos, totalizando um período de 360 dias de cultivo sob as diferentes telas de sombreamento. $O$ intervalo entre uma medida e outra foi de 45 dias, adotado pelo fato de as plantas apresentarem desenvolvimento lento.

Nos itens a seguir, são detalhadas a metodologia adotada por Kanashiro (1999), para realizar as medições nas plantas. 


\subsubsection{Altura das plantas}

A altura das plantas foi mensurada com régua graduada em centímetros, considerando a medida compreendida entre a superfície do substrato e a extremidade superior, formada pela folha mais alta.

\subsubsection{Número de folhas}

Foi feita pela contagem das folhas de cada planta, considerando-se as folhas mais desenvolvidas e aquelas mais novas, em crescimento na parte central da roseta. Não foram consideradas as folhas em processo de senescência.

\subsubsection{Maior largura da folha}

Medida tomada na folha com maior largura, utilizando-se uma régua graduada em centímetros (Figura 16).

\subsubsection{Diâmetro da roseta}

Foi determinado utilizando-se uma régua graduada em centímetros; a medida foi feita considerando-se as extremidades de duas folhas opostas que apresentam a maior dimensão.

A Figura 16 mostra um desenho esquemático de como foram realizadas as medidas do maior diâmetro e da largura da folha. 


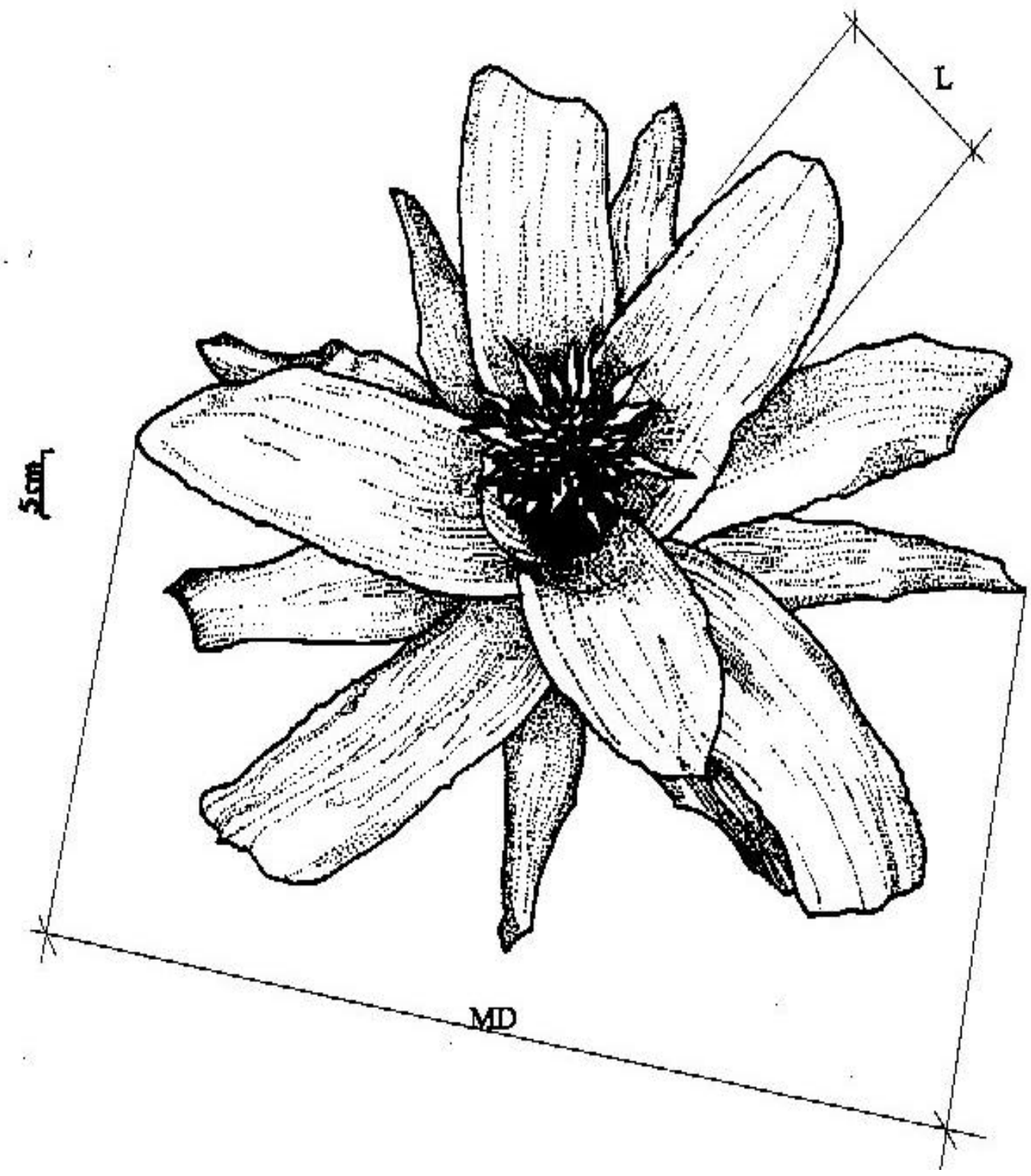

Figura 16 - Desenho esquemático, mostrando o critério adotado para a medida do maior diâmetro (MD) e da folha com maior largura (L), da espécie A. fasciata (Kanashiro, 1999). 


\subsection{Delineamento estatístico}

O delineamento estatístico, proposto por Piedade ${ }^{7}$, foi adotado de acordo com cada variável a analisar:

- Ambientes protegidos

Ambiente com altura de $3,5 \mathrm{~m}$

Ambiente com altura de $3,0 \mathrm{~m}$

- Espécie: parcela

Espécie 1: G. lingulata

Espécie 2: A. fasciata

- Luminosidade: sub parcela

Tratamento 1: tela de sombreamento de $18 \%$;

Tratamento 2: tela de sombreamento de $40 \%$;

Tratamento 3: tela de sombreamento de $60 \%$;

Tratamento 4: tela de sombreamento de $80 \%$.

Foi realizado o Teste $\mathrm{F}$ de análise de variância e, posteriormente, aplicado o Teste de Tukey, a 5\% de probabilidade, na comparação de médias, utilizando-se o Software SAS (Statistics Analisys System®).

$\mathrm{Na}$ Tabela 3, é apresentado o quadro do delineamento estatístico, inteiramente casualizado para as variáveis analisadas no interior dos ambientes (temperatura do ar, temperatura de globo negro, umidade relativa, carga térmica radiante, radiação solar).

Os blocos referem-se aos dias de coleta de dados e os tratamentos aos ambientes estudados, sendo ambiente externo, ambiente protegido com altura de $3,5 \mathrm{~m}$ e ambiente protegido com altura de $3,0 \mathrm{~m}$.

${ }^{7}$ PIEDADE, S.M. (ESALQ. Depto de Ciêcias Exatas). Comunicação pessoal, 2001. 
Tabela 3 - Delineamento inteiramente ao acaso para as variáveis microclimáticas

\begin{tabular}{cc}
\hline C.V & G.L \\
\hline Blocos & 204 \\
Tratamento & 2 \\
Resíduo & 408 \\
\hline Total & 614 \\
\hline
\end{tabular}

A Tabela 4 representa o delineamento estatístico aplicado æ̇ variáveis da parte vegetativa. Para esta análise foram coletados dados de 360 dias de desenvolvimento da planta sob as telas de sombreamento.

Tabela 4 - Delineamento inteiramente casualizado, com parcela subdividida com fatorial na parcela, para as variáveis da parte vegetativa das bromélias.

\begin{tabular}{cc}
\hline C.V & G.L \\
\hline Tela $(\mathrm{T})$ & 8 \\
Altura $(\mathrm{A})$ & 1 \\
Tx A & 8 \\
Resíduo(A) & 179 \\
\hline Total & 162 \\
\hline
\end{tabular}

A Tabela 5 representa 0 delineamento estatístico aplicado à luminosidade dos ambientes, interno e externo, e sob as telas de sombreamento. 
Tabela 5 - Blocos ao acaso no esquema fatorial $2 \times 4$, com repetição dentro de blocos, para a variável intensidade luminosa (.lux)

\begin{tabular}{cc}
\hline C.V & G.L \\
\hline Blocos (dias) & 89 \\
Rep (blo) & 90 \\
Ambientes $^{*}\left(\mathrm{~A}^{*}\right)$ & 4 \\
Altura $(A)^{*} \times \mathrm{A}$ & 1 \\
A $^{*}$ Ríduo & 4 \\
Resial & 1612 \\
\hline Total & 1800 \\
\hline
\end{tabular}

*Ambiente: leva em consideração as quatro telas de sombreamento com níveis diferentes e também o ambiente interno. 


\section{RESULTADOS E DISCUSSÃO}

A análise dos dados, apresentada a seguir, refere-se ao período de 26 de março de 2001 a 25 de fevereiro de 2002 de coleta de dados microclimáticos e ao período de 9 de abril de 2001 a 3 de abril de 2002 de coleta de dados da parte vegetativa, sendo de 360 dias de cultivo sob as telas de sombreamento.

\subsection{Características do ambiente}

\subsubsection{Temperatura do ar}

Os resultados apresentados referem-se às médias horárias de temperatura do ar, nos ambientes com alturas de 3,0 e $3,5 \mathrm{~m}$ e no ambiente externo, nos horários em que foram realizadas as leituras $(8,10,12,14,16 \mathrm{e}$ 18h).

Por meio da análise estatística, Teste de Tukey a 5\% de significância (Tabela 6), aplicada para a variável temperatura do ar, pode-se afirmar que não houve diferença significativa entre os ambientes com alturas de 3,0 e 3,5m.

Já comparando-se os ambientes protegidos com o ambiente externo, observaram-se diferenças significativas para os horários mais quentes, das 10 às $16 \mathrm{~h}$. $\mathrm{O}$ ambiente com maior altura apresentou uma redução de $0,2^{\circ} \mathrm{C}$, não gerando, portanto, resultado estatístico significativo, o que converge para as conclusões de Nascimento \& Silva (1999). Os autores, em experimento realizado em ambientes protegidos, com alturas diferenciadas (3,0 e 3,5m), 
encontraram valores de redução da temperatura do ar de $0,9^{\circ} \mathrm{C}$, para 0 ambiente com maior altura, o que estatisticamente não foi significativo, na comparação com o ambiente com menor altura, exceto para o horário de 17h.

$\mathrm{O}$ fato poder ser explicado pela relação da temperatura com a radiação solar, bem como pelo menor volume de ar a ser aquecido, no ambiente com menor altura (Martinez Garcia, 1986, Tanaka \& Genta, 1982). Segundo Buriol et. al., (1997), ambiente com maior altura possui maior volume de ar a ser aquecido e, por essa razão, o seu aquecimento é mais lento.

Tabela 6. Resultado do Teste de Tukey para as médias horárias de temperatura do $\operatorname{ar}\left({ }^{\circ} \mathrm{C}\right)$, em função dos diferentes ambientes analisados, no intervalo das 8 æ̀s 18h, ESALQ-USP, Piracicaba, SP.

\begin{tabular}{cccc}
\hline Horário & T ar $(3,5 \mathrm{~m})$ & T ar $(3,0 \mathrm{~m})$ & T externa \\
\hline 8 & $21,7 \mathrm{a}$ & $21,3 \mathrm{a}$ & $17,5 \mathrm{a}$ \\
10 & $26,1 \mathrm{a}$ & $26,9 \mathrm{a}$ & $22,4 \mathrm{~b}$ \\
12 & $29,2 \mathrm{a}$ & $29,5 \mathrm{a}$ & $27,7 \mathrm{~b}$ \\
14 & $29,9 \mathrm{a}$ & $30,1 \mathrm{a}$ & $27,1 \mathrm{~b}$ \\
16 & $28,0 \mathrm{a}$ & $28,2 \mathrm{a}$ & $26,9 \mathrm{~b}$ \\
18 & $21,7 \mathrm{a}$ & $21,8 \mathrm{a}$ & $21,9 \mathrm{a}$ \\
Média & 26,1 & 26,3 & 23,9
\end{tabular}

Médias seguidas pelas mesmas letras na mesma linha não diferem entre si, pelo Teste de Tukey ao nível de $5 \%$ de probabilidade.

As Tabelas 7 e 8 referem-se à temperatura do ar nas bancadas de cultivo, sob as telas de sombreamento com diferentes percentagens, nos ambientes estudados. A bancada de cultivo que apresentou os maiores valores de temperatura foi a que estava com a tela de sombreamento de $18 \%$, para os dois ambientes (3,5 e 3,0m). Não houve diferença significativa, entre os ambientes protegidos, para a temperatura do ar sob as diferentes telas de sombreamento. A tela com $18 \%$ de sombreamento deixava passar a maior 
quantidade de radiação, o que proporcionou os maiores valores de temperatura em ambos os ambientes, esta tela proporcionou um aumento na temperatura do ar sob as bancadas, este aumento foi de 0,6 e $0,5^{\circ} \mathrm{C}$, para os ambientes com alturas de 3,5 e 3,0m respectivamente. Entre o ambiente externo e a tela de $18 \%$ este aumento foi de 2,8 e $2,9^{\circ} \mathrm{C}$ para as mesmas alturas dos ambientes protegidos.

As telas de sombreamento de 40,60 e $80 \%$, usadas sobre as bancadas de cultivo proporcionaram uma atenuação da temperatura do ar em ambos os ambientes, em relação ao ambiente externo. As telas de sombreamento com 60 e $80 \%$ proporcionaram os maiores valores de atenuação da temperatura do ar. Para o ambiente $\infty \mathrm{m}$ altura de 3,5m a atenuação para as telas de 60 e $80 \%$ variou entre 1,0 e $0,9^{\circ} \mathrm{C}$ e para o ambiente com altura de $3,0 \mathrm{~m}$ a atenuação variou entre 0,9 e $1,0^{\circ} \mathrm{C}$, respectivamente. Isto ocorreu devido às características do material utilizado, estas telas são as que barram maior quantidade de radiação solar incidente, quando comparadas com as telas de 18 e 40\%, consequentemente influenciando na temperatura.

Tabela 7. Resultado do Teste de Tukey para as médias horárias de temperatura do ar $\left({ }^{\circ} \mathrm{C}\right)$, sob as telas de sombreamento com diferentes percentagens no ambiente protegido com altura de $3,5 \mathrm{~m}$, no intervalo das 8 à 18h, ESALQ-USP, Piracicaba, SP.

\begin{tabular}{ccccc}
\hline Horário & Tela 18\% & Tela 40\% & Tela 60\% & Tela 80\% \\
\hline 8 & $21,7 \mathrm{a}$ & $21,2 \mathrm{~b}$ & $20,6 \mathrm{~b}$ & $20,7 \mathrm{~b}$ \\
10 & $25,8 \mathrm{a}$ & $24,6 \mathrm{~b}$ & $24,4 \mathrm{~b}$ & $24,4 \mathrm{~b}$ \\
12 & $29,6 \mathrm{a}$ & $27,6 \mathrm{~b}$ & $27,6 \mathrm{~b}$ & $27,8 \mathrm{~b}$ \\
14 & $32,1 \mathrm{a}$ & $29,6 \mathrm{~b}$ & $29,6 \mathrm{~b}$ & $29,7 \mathrm{~b}$ \\
16 & $28,4 \mathrm{a}$ & $26,4 \mathrm{~b}$ & $26,2 \mathrm{~b}$ & $26,1 \mathrm{~b}$ \\
18 & $22,5 \mathrm{a}$ & $22,4 \mathrm{a}$ & $21,9 \mathrm{a}$ & $22,2 \mathrm{a}$ \\
Média & 26,7 & 25,3 & 25,1 & 25,2 \\
\hline Médias seguidas pelas mesmas Ietras na mesma linha näo diferem entre si, pelo Teste de Tukey ao nivel de $5 \%$ de probabilidade.
\end{tabular}


Tabela 8. Resultado do Teste de Tukey para as médias horárias de temperatura do ar $\left({ }^{\circ} \mathrm{C}\right)$, sob as telas de sombreamento com diferentes percentagens no ambiente protegido com altura de $3,0 \mathrm{~m}$, no intervalo das 8 æे 18h, ESALQ-USP, Piracicaba, SP.

\begin{tabular}{|c|c|c|c|c|}
\hline Horário & Tela 18\% & Tela $40 \%$ & Tela $60 \%$ & Tela $80 \%$ \\
\hline 8 & $22,0 \mathrm{a}$ & $21,4 b$ & $21,0 \mathrm{~b}$ & $21,0 \mathrm{~b}$ \\
\hline 10 & $26,5 \mathrm{a}$ & $25,6 b$ & $25,3 b$ & $25,2 b$ \\
\hline 12 & $29,5 \mathrm{a}$ & $29,0 \mathrm{~b}$ & $27,8 \mathrm{~b}$ & $27,8 \mathrm{~b}$ \\
\hline 14 & $32,6 \mathrm{a}$ & $30,4 \mathrm{~b}$ & $29,7 b$ & 29,6 b \\
\hline 16 & $28,2 \mathrm{a}$ & $26,2 b$ & $26,7 \mathrm{~b}$ & $26,5 b$ \\
\hline 18 & $21,9 \mathrm{a}$ & $21,9 a$ & $22,0 \mathrm{a}$ & $21,5 \mathrm{a}$ \\
\hline Média & 26,8 & 25,8 & 25,4 & 25,3 \\
\hline
\end{tabular}

\subsubsection{Umidade relativa do ar}

Os valores de umidade relativa do ar, no interior dos ambientes protegidos, são muito variáveis, e estão intimamente relacionados aos valores de temperatura do ar. Por sua vez, a temperatura do ar varia principalmente em função da densidade da radiação solar incidente e da própria ventilação, a qual depende da área, da localização e do manejo das aberturas, bem como da velocidade de troca do ar entre o interior e o exterior dos ambientes. Assim, para um mesmo conteúdo de vapor d'água no ar, a umidade relativa é inversamente proporcional àtemperatura (Prados, 1986; Buriol et al., 2000).

Observando as temperatura do ar e a umidade relativa nos ambientes protegidos, nota-se que à medida que a temperatura se eleva, a umidade relativa tende a diminuir, o que converge para as conclusões do autor citado anteriormente. 
Na Tabela 9, são apresentados os resultados de umidade relativa do ar, observados tanto no interior dos ambientes protegidos quanto no ambiente externo. Os maiores valores de umidade relativa do ar foram encontrados no ambiente com altura de $3,5 \mathrm{~m}$, para todos os horários.

Considerando-se a média ao longo do dia, o ambiente com menor altura apresentou uma redução de 1,0 ponto percentual na umidade relativa, em relação ao ambiente com maior altura; as maiores diferenças foram verificadas nos horários das 10 e $14 \mathrm{~h}$, sendo de 1,3 e 1,1 ponto percentual, respectivamente.

Com base na análise estatística realizada pelo Teste de Tukey a 5\% de significância, observou que não houve diferença significativa na umidade relativa entre os ambientes com alturas de 3,0 e $3,5 \mathrm{~m}$. O fato de ter se aumentado o volume de ar no ambiente de $3,5 \mathrm{~m}$, por meio da elevação do pé direito da estufa não promoveu variações significativas nos valores de umidade relativa do ar, pois, manteve-se a mesma área de exposição do solo, no caso $112,0 \mathrm{~m}^{2}$, resultado concordante com Nascimento \& Silva (2000), que não encontraram diferenças significativas entre os ambientes com a mesma altura.

Isto pode ser explicado pelo fato do ambiente com maior altura possuir um maior volume de ar, consequentemente uma maior quantidade vapor de água existente na massa de ar, dificultando assim o processo evaporativo. $O$ aumento de volume se deu somente no sentido vertical, ou seja, a área de solo, que é a que mais sofre o efeito da evaporação é a mesma para ambos ambientes, sendo assim, os valores de umidade são mais acentuados no ambiente com maior volume, concordando com Seemann, 1979 e Sganzerla, 1995.

Observou que os valores médios de umidade relativa do ar, para o ambiente com altura de $3,5 \mathrm{~m}$ e o exterior foi de 57,4 e $57,5 \%$, respectivamente; não apresentando portanto, diferença significativa. A maior diferença foi encontrada entre o ambiente com altura de $3,0 \mathrm{~m}$ e o ambiente externo, sendo esta diferença de 1,1 ponto percentual, mas esta diferença não foi significativa. 
Verifica-se na Tabela 9 entre os horários das 8 e 10h e 16 e 18h, que ouve uma variação média de 28 e 25,2 pontos percentuais, respectivamente, para ambos ambientes protegidos estudados. Este fato ocorreu devido ao manejo com as cortinas laterais, o que influenciou na redução da umidade relativa a partir das $8 \mathrm{~h}$ e no aumento æ̀ $18 \mathrm{~h}$.

Tabela 9. Resultados do Teste de Tukey, para as médias horárias de umidade relativa do ar (UR\%) coletadas nos ambientes internos (3,0 e 3,5m de altura) e no ambiente externo, no intervalo das 8 à 18h, ESALQUSP, Piracicaba, SP.

\begin{tabular}{cccc}
\hline Horário & UR $(3,5 \mathrm{~m})$ & UR $(3,0 \mathrm{~m})$ & UR externa \\
\hline 8 & $82,7 \mathrm{a}$ & $82,2 \mathrm{a}$ & $79,0 \mathrm{~b}$ \\
10 & $54,7 \mathrm{a}$ & $53,4 \mathrm{a}$ & $62,5 \mathrm{~b}$ \\
12 & $45,0 \mathrm{a}$ & $44,0 \mathrm{a}$ & $51,1 \mathrm{~b}$ \\
14 & $42,7 \mathrm{a}$ & $41,6 \mathrm{a}$ & $45,9 \mathrm{~b}$ \\
16 & $47,0 \mathrm{a}$ & $46,0 \mathrm{a}$ & $45,5 \mathrm{~b}$ \\
18 & $72,2 \mathrm{a}$ & $71,2 \mathrm{a}$ & $61,0 \mathrm{~b}$ \\
Média & 57,4 & 56,4 & 57,5 \\
\hline Médias seguidas pelas mesmas letras na mesma linha não diferem entre si, pelo Teste de Tukey ao nivel de $5 \%$ de \\
probabilidade.
\end{tabular}

As Tabelas 10 e 11 referem-se à umidade relativa do ar no interior das bancadas de cultivo, sob as telas de sombreamento com diferentes percentagens nos ambientes estudados. As bancadas de cultivo que apresentaram os maiores valores de umidade relativa foram a que estavam com a tela de sombreamento de 60 e $80 \%$, porém os valores encontrados não foram significativos entre os dois ambientes estudados (3,5 e 3,0m).

A tela com $18 \%$ de sombreamento deixava passar a maior quantidade de radiação, o que proporcionou os menores valores médios de umidade relativa, $55,8 \%$ para ambos os ambientes. A bancada com tela de $80 \%$ proporcionou um 
aumento na umidade relativa média do ar em relação ao ambiente, sendo este aumento de 6,4 pontos percentuais para o ambiente com altura 3,5m e 7,2 pontos percentuais para o ambiente com menor altura. Ficando claro que, quanto maior a temperatura, menor será a umidade relativa de um ambiente, concordando com Buriol et al., 2000).

Deve-se ressaltar que as variações da umidade relativa do ar no interior das bancadas está diretamente relacionado com a trama das diferentes telas, que permitem a maior ou menor movimentação da massa de ar no seu interior, e consequentemente as trocas com o meio externo. Dessa forma verificou-se que as telas com $18 \%$ apresentou os menores valores de umidade relativa quando comparado com a tela de $80 \%$, porém, sendo estas diferenças estatísticas significativas.

Tabela 10. Resultado do Teste de Tukey para as médias horárias de umidade relativa do ar (\%), sob as telas de sombreamento com diferentes percentagens no ambiente protegido com altura de $3,5 \mathrm{~m}$, no intervalo das 8 às 18h, ESALQ-USP, Piracicaba, SP.

\begin{tabular}{|c|c|c|c|c|}
\hline Horário & Tela $18 \%$ & Tela $40 \%$ & Tela $60 \%$ & Tela $80 \%$ \\
\hline 8 & $73,2 \mathrm{~b}$ & $71,5 \mathrm{~b}$ & $73,8 \mathrm{~b}$ & $79,3 \mathrm{a}$ \\
\hline 10 & $57,8 \mathrm{~b}$ & $57,0 \mathrm{~b}$ & $61,7 \mathrm{~b}$ & $68,6 \mathrm{a}$ \\
\hline 12 & $47,0 \mathrm{~b}$ & $49,3 \mathrm{~b}$ & $50,6 \mathrm{~b}$ & $53,1 a$ \\
\hline 14 & $45,4 \mathrm{~b}$ & $49,0 \mathrm{~b}$ & $47,3 b$ & $55,2 a$ \\
\hline 16 & $51,7 \mathrm{~b}$ & $54,7 \mathrm{~b}$ & $56,9 \mathrm{~b}$ & $61,5 \mathrm{a}$ \\
\hline 18 & 59,6 b & $58,4 \mathrm{~b}$ & $62,9 \mathrm{~b}$ & $65,3 a$ \\
\hline Média & 55,8 & 56,7 & 58,9 & 63,8 \\
\hline
\end{tabular}


Tabela 11. Resultado do Teste de Tukey para as médias horárias de umidade relativa do ar (\%), sob as telas de sombreamento com diferentes percentagens no ambiente protegido com altura de $3,0 \mathrm{~m}$, no intervalo das 8 às 18h, ESALQ-USP, Piracicaba, SP.

\begin{tabular}{|c|c|c|c|c|}
\hline Horário & Tela 18\% & Tela $40 \%$ & Tela $60 \%$ & Tela $80 \%$ \\
\hline 8 & 71,2 b & $72,7 \mathrm{~b}$ & $74,3 \mathrm{~b}$ & $78,5 \mathrm{a}$ \\
\hline 10 & $56,6 \mathrm{~b}$ & $61,1 \mathrm{~b}$ & $64,6 \mathrm{~b}$ & $67,8 \mathrm{a}$ \\
\hline 12 & $50,0 \mathrm{~b}$ & $49,0 \mathrm{~b}$ & $51,3 b$ & $54,6 \mathrm{a}$ \\
\hline 14 & $44,4 \mathrm{~b}$ & $47,9 \mathrm{~b}$ & $50,6 \mathrm{~b}$ & $54,8 \mathrm{a}$ \\
\hline 16 & $50,3 b$ & $55,0 \mathrm{~b}$ & $53,6 b$ & $60,3 a$ \\
\hline 18 & $62,5 \mathrm{~b}$ & $63,9 \mathrm{~b}$ & $62,4 \mathrm{~b}$ & $65,6 \mathrm{a}$ \\
\hline Média & 55,8 & 58,2 & 59,5 & 63,6 \\
\hline
\end{tabular}

\subsubsection{Radiação solar global}

$\mathrm{Na}$ Tabela 12, são apresentados os valores médios de radiação solar global $\left(\mathrm{W} / \mathrm{m}^{2}\right)$ observados no interior dos ambientes protegidos e no ambiente externo.

Com base na análise estatística realizada pelo Teste de Tukey a 5\% de significância, observa-se que não houve diferença significativa entre os ambientes com alturas de 3,0 e 3,5m, exceto para o horário das $18 \mathrm{~h}$.

O ambiente com menor altura teve redução de $11,2 \mathrm{~W} / \mathrm{m}^{2}$, em relação ao ambiente com maior altura; isso pode ser explicado pelo fato de o ambiente com maior altura apresentar uma maior área lateral exposta à incidência de radiação solar, devido ao aumento de $0,5 \mathrm{~m}$ no pé direito.

Observa-se que a maior transmissividade da cobertura plástica à radiação solar ocorreu das 10 às $14 \mathrm{~h}$, sendo menor nos horários de menor 
elevação solar. A maior diferença encontrada entre os ambientes ocorreu no horário das $12 \mathrm{~h}$, e foi de $25,8 \mathrm{~W} / \mathrm{m}^{2}$ maior, no ambiente com altura de $3,5 \mathrm{~m}$.

A radiação solar global, no ambiente externo, foi superior à dos dois ambientes protegidos, encontrando-se uma maior diferença quando se compara o ambiente externo com o ambiente com altura de 3,5m; o valor é de 169,4 $\mathrm{W} / \mathrm{m}^{2}$, convergindo para as conclusões de Pezzopane (1994), que afirma que a radiação solar, incidente no interior de um ambiente protegido, é sempre menor que a que incide numa superfície livre.

Considerando que a radiação solar incidente externa é 100\%, verifica-se por meio dos valores médios que o ambiente protegido com altura 3,5m teve uma redução de 58,6\% e o ambiente 3,0 m teve uma redução de $55,7 \%$.

Tabela 12. Resultados do Teste de Tukey para as médias horárias de radiação solar $\left(\mathrm{W} / \mathrm{m}^{2}\right)$ coletadas nos ambientes internos $(3,0$ e $3,5 \mathrm{~m}$ de altura) e no ambiente externo, no intervalo das 8 æ̀ 18h, ESALQUSP, Piracicaba, SP.

\begin{tabular}{cccc}
\hline Horário & RS (3,5m) & RS (3,0m) & RS externa \\
\hline 8 & $114,5 \mathrm{~b}$ & $123,5 \mathrm{~b}$ & $241,8 \mathrm{a}$ \\
10 & $352,8 \mathrm{~b}$ & $338,5 \mathrm{~b}$ & $580,6 \mathrm{a}$ \\
12 & $404,8 \mathrm{~b}$ & $379,0 \mathrm{~b}$ & $676,7 \mathrm{a}$ \\
14 & $333,3 \mathrm{~b}$ & $308,3 \mathrm{~b}$ & $531,2 \mathrm{a}$ \\
16 & $136,3 \mathrm{~b}$ & $126,9 \mathrm{~b}$ & $260,5 \mathrm{a}$ \\
18 & $2,7 \mathrm{a}$ & $0,9 \mathrm{~b}$ & $2,7 \mathrm{a}$ \\
Média & 224,1 (58,6\%) & 212,9 (55,7\%) & $382,3(100 \%)$ \\
\hline Médias seguidas pelas mesmas letras na mesma linha não diferem entre si, pelo Teste de Tukey ao nivel de 5\% de \\
probabilidade.
\end{tabular}


4.1.4 Temperatura de Globo Negro (TGN) e Carga Térmica Radiante (CTR)

À medida que aumenta a altura de um ambiente, as plantas contidas em seu interior ficam expostas a uma maior incidência de radiação, pelo fato de que o ambiente com maior altura recebe uma maior quantidade de radiação solar, isto se deve à sua maior superfície receptora nas laterais, em função da declinação solar.

Os valores da Tabela 13 referem-se à análise estatística, pelo Teste de Tukey a $5 \%$ de significância, para a temperatura do globo negro $\left({ }^{\circ} \mathrm{C}\right)$ e a carga térmica radiante $\left(\mathrm{W} / \mathrm{m}^{2}\right)$. Observourse que a elevação da altura do ambiente em $0,5 \mathrm{~m}$ proporcionou um aumento médio da temperatura de globo negro, e conseqüentemente, da carga térmica radiante, quando comparado com o ambiente externo, sendo esse aumento de $3,0^{\circ} \mathrm{C}$ e $168,5 \mathrm{~W} / \mathrm{m}^{2}$, respectivamente. Para o ambiente com menor altura este aumento foi de $2,4^{\circ} \mathrm{C}$ e $168,4 \mathrm{~W} / \mathrm{m}^{2}$.

As variações nos valores são mais evidentes nos horários mais quentes do dia, entre 12 e 14h. Porém, não foram observadas diferenças significativas para os valores médios de temperatura de globo negro e da carga térmica radiante para os horários das 8 æ̀ $18 \mathrm{~h}$, resultados observados também por Nascimento \& Silva (2000).

Apesar das diferenças dos ambientes, em relação ao volume interno, ambos receberam a mesma quantidade de água, proveniente da nebulização e da microaspersão. Portanto o ambiente com menor volume de ar irá ter uma maior quantidade de vapor de água no seu interior, em relação ao volume de ar total. 
Tabela 13. Resultado do Teste de Tukey para as médias horárias de Temperatura de Globo Negro $\left(\mathrm{TGN}-{ }^{\circ} \mathrm{C}\right.$ ) e Carga Térmica Radiante (CTR - $\mathrm{W} / \mathrm{m}^{2}$ ), medidos no interior dos ambientes com alturas de 3,5 e 3,0m e no exterior, no intervalo das 8 às $18 \mathrm{~h}$, ESALQ-USP, Piracicaba, SP.

\begin{tabular}{ccccccc}
\hline Horário & TGN 3,5m & TGN 3,0m & TGN ext & CTR 3,5m & CTR 3,0m & CTR ext \\
\hline 8 & $27,4 \mathrm{~b}$ & $27,4 \mathrm{~b}$ & $36,4 \mathrm{a}$ & $474,6 \mathrm{~b}$ & $470,3 \mathrm{~b}$ & $662,6 \mathrm{a}$ \\
10 & $37,6 \mathrm{~b}$ & $36,9 \mathrm{~b}$ & $41,3 \mathrm{a}$ & $545,5 \mathrm{~b}$ & $553,7 \mathrm{~b}$ & $779,6 \mathrm{a}$ \\
12 & $41,5 \mathrm{a}$ & $41,0 \mathrm{a}$ & $43,1 \mathrm{~b}$ & $605,3 \mathrm{~b}$ & $585,0 \mathrm{~b}$ & $780,3 \mathrm{a}$ \\
14 & $42,6 \mathrm{a}$ & $40,6 \mathrm{a}$ & $45,6 \mathrm{~b}$ & $610,5 \mathrm{~b}$ & $561,1 \mathrm{~b}$ & $806,3 \mathrm{a}$ \\
16 & $33,8 \mathrm{~b}$ & $33,9 \mathrm{~b}$ & $39,4 \mathrm{a}$ & $522,2 \mathrm{~b}$ & $553,1 \mathrm{~b}$ & $708,8 \mathrm{a}$ \\
18 & $22,9 \mathrm{a}$ & $22,4 \mathrm{a}$ & $24,9 \mathrm{~b}$ & $429,8 \mathrm{~b}$ & $425,2 \mathrm{~b}$ & $461,4 \mathrm{a}$ \\
Média & 34,3 & 33,7 & 31,3 & 531,3 & 531,4 & 699,8 \\
\hline
\end{tabular}

No interior das bancadas, sob as diferentes telas de sombreamento, foram medidos a temperatura de globo negro; observou-se que, entre os ambientes com alturas diferentes não houve diferenças significativas. Porém quando comparado as telas num mesmo ambiente nota-se diferenças significativas.

As Tabelas 14 e 15 mostram os valores médios horários de temperatura de globo negro sob as telas de sombreamento, nos ambientes com alturas 3,5e $3,0 \mathrm{~m}$, respectivamente. Pela análise estatística, realizada pelo Teste de Tukey a $5 \%$ de significância, conclui-se que houve diferença significativa entre a tela de $18 \%$ e as telas de 40,60 e $80 \%$ de sombreamento, sendo estas diferenças, para o ambiente com altura de 3,5m, de 2,0, 4,5 e $4^{\circ} \mathrm{C}$, respectivamente. Para o ambiente com altura de $3,0 \mathrm{~m}$ estas diferenças foram de $3,5,5,0$ e $5,2^{\circ} \mathrm{C}$, respectivamente. As telas de 60 e $80 \%$ de sombreamento, quando comparadas não apresentaram diferenças significativas. 
Os maiores valores de temperatura de globo negro foram registrados para ambos ambientes no horário das $14 \mathrm{~h}$, coincidindo com os maiores valores de temperatura do ar no interior das bancadas. Observa-se que o maior valor da temperatura do globo negro encontra-se na bancada com tela de sombreamento de $18 \%$, ou seja, a tela que mais deixa passar radiação solar, com isso o termômetro de globo negro registrou os maiores valores.

Tabela 14. Resultado do Teste de Tukey para as médias horárias de temperatura de globo negro $\left({ }^{\circ} \mathrm{C}\right)$, sob as telas de sombreamento com diferentes percentagens no ambiente protegido com altura de 3,5m, no intervalo das 8 æ̀ $18 \mathrm{~h}$, ESALQ-USP, Piracicaba, SP.

\begin{tabular}{|c|c|c|c|c|}
\hline Horário & Tela $18 \%$ & Tela $40 \%$ & Tela $60 \%$ & Tela $80 \%$ \\
\hline 8 & $26,4 \mathrm{a}$ & $25,1 b$ & $23,2 \mathrm{c}$ & $23,1 \mathrm{c}$ \\
\hline 10 & $31,0 \mathrm{a}$ & $29,1 \mathrm{~b}$ & $26,2 \mathrm{c}$ & $27,0 \mathrm{c}$ \\
\hline 12 & $35,5 \mathrm{a}$ & $32,7 b$ & $29,3 \mathrm{c}$ & $30,4 \mathrm{c}$ \\
\hline 14 & $38,8 \mathrm{a}$ & $35,3 b$ & $31,3 \mathrm{c}$ & $32,2 \mathrm{c}$ \\
\hline 16 & $31,8 \mathrm{a}$ & 29,8 b & $27,7 \mathrm{c}$ & $27,5 \mathrm{c}$ \\
\hline 18 & $24,3 \mathrm{a}$ & $24,0 a b$ & $23,0 \mathrm{c}$ & $23,2 \mathrm{bc}$ \\
\hline Média & 31,3 & 29,3 & 26,8 & 27,3 \\
\hline
\end{tabular}


Tabela 15. Resultado do Teste de Tukey para as médias horárias de temperatura de globo negro $\left({ }^{\circ} \mathrm{C}\right)$, sob as telas de sombreamento com diferentes percentagens no ambiente protegido com altura de 3,0m, no intervalo das 8 às 18h, ESALQ-USP, Piracicaba, SP.

\begin{tabular}{|c|c|c|c|c|}
\hline Horário & Tela 18\% & Tela $40 \%$ & Tela $60 \%$ & Tela $80 \%$ \\
\hline 8 & $27,5 \mathrm{a}$ & $25,2 \mathrm{~b}$ & $24,1 \mathrm{c}$ & $23,6 \mathrm{c}$ \\
\hline 10 & $34,2 \mathrm{a}$ & $30,7 b$ & $28,1 \mathrm{c}$ & $27,8 \mathrm{c}$ \\
\hline 12 & $38,0 a$ & $33,0 \mathrm{~b}$ & $30,8 \mathrm{c}$ & $30,6 \mathrm{c}$ \\
\hline 14 & $40,1 \mathrm{a}$ & $34,9 b$ & $32,8 \mathrm{c}$ & $32,2 \mathrm{c}$ \\
\hline 16 & $32,7 \mathrm{a}$ & $27,8 \mathrm{~b}$ & $27,4 \mathrm{~b}$ & $27,6 \mathrm{~b}$ \\
\hline 18 & $23,1 \mathrm{a}$ & $23,0 \mathrm{a}$ & $22,4 \mathrm{a}$ & $22,7 \mathrm{a}$ \\
\hline Média & 32,6 & 29,1 & 27,6 & 27,4 \\
\hline
\end{tabular}

\subsubsection{Intensidade luminosa}

A quantidade de luz, que atinge o ambiente, tem influência direta no desenvolvimento das bromélias, determinando sua forma, seu tamanho e sua coloração (Carvalho \& Rocha, 1999).

As coberturas dos ambientes protegidos foram instaladas na mesma época; portanto possuem a mesma idade. As diferenças observadas entre os ambientes devem-se æ̀ condições atmosféricas no momento das leituras e à deposição de poeira sobre as coberturas plásticas (Kai et al., 1999, Fugiwara, 2000).

A Tabela 16 apresenta os resultados de intensidade luminosa entre os ambientes protegidos com 3,5 e 3,0m de altura. Nos horários com maior intensidade luminosa, ou seja, das 10 æ̀ $14 \mathrm{~h}$ não foram observadas diferenças significativas, esses resultados concordam comas conclusões de Farias et al. (1993) e Nascimento \& Silva (2000), que encontraram maiores valores de 
intensidade luminosa no mesmo horário, e as menores, nos horários das 8 e 18h, não apresentando diferenças significativas entre eles.

As diferenças não foram significativas devido ao fato do material de cobertura ser o mesmo em ambos os ambientes e com a mesma idade de uso, o efeito altura do ambiente não afetou o nível de luminosidade interna.

Tabela 16. Resultado do Teste de Tukey para as médias horárias de intensidade luminosa (lux) entre os ambientes com alturas de 3,5 e 3,0m, no intervalo das 8 às 18h, ESALQ-USP, Piracicaba, SP.

\begin{tabular}{ccc}
\hline Horário & Ambiente 3,5m & Ambiente 3,0m \\
\hline 8 & $2575,5 \mathrm{a}$ & $2862,4 \mathrm{a}$ \\
10 & $5895,5 \mathrm{a}$ & $6137,2 \mathrm{a}$ \\
12 & $7942,4 \mathrm{a}$ & $8177,6 \mathrm{a}$ \\
14 & $7038,6 \mathrm{a}$ & $7042,8 \mathrm{a}$ \\
16 & $2661,0 \mathrm{a}$ & $2400,7 \mathrm{a}$ \\
18 & $436,2 \mathrm{a}$ & $380,3 \mathrm{a}$
\end{tabular}

Médias seguidas pelas mesmas letras e na mesma linha não diferem entre si, pelo Teste de Tukey ao nível de $5 \%$ de probabilidade.

As Tabelas 17 e 18, apresentadas abaixo, referem-se à análise estatística pelo Teste de Tukey a $5 \%$ de significância. Foi analisada a intensidade luminosa (lux) nos ambientes protegidos e nas bancadas de cultivo, sob as diferentes telas de sombreamento. Observa-se que houve diferença significativa do ambiente (sem tela), em relação aos quatro níveis de sombreamento estudados. As telas de sombreamento com 18, 40 e $60 \%$ diferiram entre si, pelo Teste de Tukey em todos os horários observados. Somente as telas com níveis de 60 e $80 \%$ de sombreamento não apresentaram diferenças estatísticas significativas, pelo mesmo teste. 
Tabela 17. Resultado do Teste de Tukey para as médias horárias de intensidade luminosa (lux), relacionando a altura $(3,5 \mathrm{~m})$ e as diferentes telas de sombreamento, no intervalo das 8 à $18 \mathrm{~h}$, ESALQ-USP, Piracicaba, SP.

\begin{tabular}{cccccc}
\hline Horário & S/ tela & Tela 18\% & Tela 40\% & Tela 60\% & Tela 80\% \\
\hline 8 & $2575,5 \mathrm{a}$ & $1385,3 \mathrm{~b}$ & $955,7 \mathrm{c}$ & $353,6 \mathrm{~d}$ & $221,4 \mathrm{~d}$ \\
10 & $5895,5 \mathrm{a}$ & $3880,3 \mathrm{~b}$ & $2523,6 \mathrm{c}$ & $922,0 \mathrm{~d}$ & $652,2 \mathrm{~d}$ \\
12 & $7942,4 \mathrm{a}$ & $5880,3 \mathrm{~b}$ & $3380,9 \mathrm{c}$ & $1419,8 \mathrm{~d}$ & $954,3 \mathrm{~d}$ \\
14 & $7038,6 \mathrm{a}$ & $4506,9 \mathrm{~b}$ & $2469,3 \mathrm{c}$ & $1196,7 \mathrm{~d}$ & $871,7 \mathrm{~d}$ \\
16 & $2661,0 \mathrm{a}$ & $1182,4 \mathrm{~b}$ & $833,6 \mathrm{c}$ & $683,3 \mathrm{~d}$ & $230,3 \mathrm{~d}$ \\
18 & $436,2 \mathrm{a}$ & $227,1 \mathrm{~b}$ & $119,7 \mathrm{c}$ & $58,8 \mathrm{~d}$ & $33,1 \mathrm{~d}$ \\
\hline
\end{tabular}

Tabela 18. Resultado do Teste de Tukey para as médias horárias de intensidade luminosa (lux), relacionando a altura $(3,0 \mathrm{~m})$ e as diferentes telas de sombreamento, no intervalo das 8 às 18h, ESALQ-USP, Piracicaba, SP.

\begin{tabular}{cccccc}
\hline Horário & S/ tela & Tela 18\% & Tela 40\% & Tela 60\% & Tela 80\% \\
\hline 8 & $2862,4 \mathrm{a}$ & $1713,1 \mathrm{~b}$ & $1013,8 \mathrm{c}$ & $409,1 \mathrm{~d}$ & $284,5 \mathrm{~d}$ \\
10 & $6137,2 \mathrm{a}$ & $3967,1 \mathrm{~b}$ & $2576,7 \mathrm{c}$ & $936,2 \mathrm{~d}$ & $610,9 \mathrm{~d}$ \\
12 & $8177,6 \mathrm{a}$ & $5569,1 \mathrm{~b}$ & $3474,8 \mathrm{c}$ & $1312,8 \mathrm{~d}$ & $908,8 \mathrm{~d}$ \\
14 & $7042,8 \mathrm{a}$ & $4445,0 \mathrm{~b}$ & $2568,4 \mathrm{c}$ & $1117,6 \mathrm{~d}$ & $843,1 \mathrm{~d}$ \\
16 & $2400,7 \mathrm{a}$ & $1272,2 \mathrm{~b}$ & $683,3 \mathrm{c}$ & $289,3 \mathrm{~d}$ & $181,0 \mathrm{~d}$ \\
18 & $380,3 \mathrm{a}$ & $191,9 \mathrm{~b}$ & $93,6 \mathrm{c}$ & $64,8 \mathrm{~d}$ & $21,2 \mathrm{~d}$ \\
\hline
\end{tabular}

As telas de sombreamento que mais impedem a passagem da luminosidade são as de 60 e $80 \%$, mostrando-se prejudiciais ao 
desenvolvimento das plantas das espécie $A$. fasciata, a qual não apresenta tolerância ao sombreamento excessivo. Já a espécie G. lingulata apresentou uma maior tolerância ao sombreamento, o que pode ser verificado pelo desenvolvimento das plantas sob os diferentes níveis de sombreamento.

A tela que apresentou melhores resultados, em relação ao desenvolvimento das plantas de $A$. fasciata, foi a de $40 \%$ de sombreamento e, para a G. lingulata, as telas com 60 e $80 \%$ de sombreamento.

As telas de sombreamento tem como finalidade básica o impedimento da passagem de luz para o ambiente. Por sua vez, verifica-se que das telas de sombreamento existentes no comércio existem aquelas que apresentam diferenças significativas entre elas. Em função da tela verifica-se também existem níveis em que a variação não e significativa, tendo como exemplos as telas de 60 e 80\%, apresentadas nos resultados das Tabelas 17 e 18.

\subsection{Características do desenvolvimento da planta}

Sendo as bromélias plantas que sofrem a influência direta da luz, são apresentados a seguir os resultados, do seu cultivo sob as diferentes telas de sombreamento, totalizando 360 dias.

São apresentados abaixo, os valores médios das variáveis altura, número de folhas, largura da terceira folha e diâmetro da roseta das espécies $A$. fasciata e $G$. lingulata. Essas medidas foram realizadas ao longo do período de cultivo, sendo coletados dados aos 20,65, 110,155, 200, 245, 290, 335 e 380 dias. 


\subsubsection{Aechmea fasciata}

\subsubsection{Altura das plantas}

Partindo do princípio de que o produto final é o de maior importância para a comercialização, analisamos os dados de 360 dias de cultivo sob as diferentes telas de sombreamento, que ocorreu no $338^{\circ}$ dia.

Nas Tabelas 19 e 20, são apresentados os valores médios da altura das plantas, nos ambientes de 3,0 e 3,5m de altura. As plantas sob as telas de $18 \%$ de sombreamento tiveram seu crescimento prejudicado pela maior incidência de luz, apresentando folhas amareladas e com queimaduras.

As plantas sob as telas de sombreamento de 60 e $80 \%$ também tiveram seu crescimento prejudicado. A altura foi afetada pelo fato de as plantas apresentarem folhas com menor rigidez, fazendo com que se dobrassem sobre si, diminuindo assim, a sua altura. Isso ocorre pelo excesso de sombra a que ficaram expostas as plantas, causando estiolamento (Carvalho \& Rocha, 1999).

Observa-se um melhor desenvolvimento das plantas, com relação à altura, no tratamento com o sombreamento de $40 \%$, pois todas as 20 plantas da bancada apresentaram altura uniforme.

Baseando-se nos resultados apresentados verifica-se que no ambiente com 3,5m de altura as telas de 40,60 e 80\% apresentaram plantas com a mesma média de altura, diferindo das telas de 18\%. Porém, apesar de não apresentarem diferenças estatísticas observa-se visualmente que as plantas cultivadas sob as telas de 60 e $80 \%$ não apresentaram as características, como cor e forma da planta, desejáveis da espécie (Lorenzi, 1999).

O mesmo resultado foi observado para o ambiente com altura de $3,0 \mathrm{~m}$. 
Tabela 19. Resultado do Teste de Tukey para a variável altura da planta $(\mathrm{cm})$, em função dos sombreamentos e da altura do ambiente protegido $(3,5 \mathrm{~m})$, da espécie A. fasciata, ESALQ-USP, Piracicaba, SP.

\begin{tabular}{lccccccccc}
\hline \multicolumn{1}{c}{ Telas } & 20 & 65 & 110 & 155 & 200 & 245 & 290 & 335 & 380 \\
\hline $18 \%$ & $4,6 \mathrm{a}$ & $9,0 \mathrm{c}$ & $11,0 \mathrm{~b}$ & $14,7 \mathrm{~b}$ & $26,4 \mathrm{a}$ & $27,4 \mathrm{~b}$ & $29,9 \mathrm{a}$ & $28,5 \mathrm{~b}$ & $29,4 \mathrm{~b}$ \\
$40 \%$ & $5,3 \mathrm{a}$ & $11,6 \mathrm{ab}$ & $13,1 \mathrm{~b}$ & $18,5 \mathrm{a}$ & $28,3 \mathrm{a}$ & $28,1 \mathrm{ab}$ & $30,1 \mathrm{ab}$ & $30,8 \mathrm{a}$ & $34,5 \mathrm{a}$ \\
$60 \%$ & $5,5 \mathrm{a}$ & $13,3 \mathrm{a}$ & $15,4 \mathrm{a}$ & $18,3 \mathrm{a}$ & $29,8 \mathrm{a}$ & $29,4 \mathrm{ab}$ & $30,9 \mathrm{a}$ & $32,2 \mathrm{a}$ & $34,6 \mathrm{a}$ \\
$80 \%$ & $4,9 \mathrm{a}$ & $11,4 \mathrm{~b}$ & $13,2 \mathrm{ab}$ & $17,2 \mathrm{ab}$ & $26,4 \mathrm{a}$ & $31,2 \mathrm{a}$ & $31,3 \mathrm{a}$ & $32,3 \mathrm{a}$ & $33,6 \mathrm{a}$ \\
\hline
\end{tabular}

Tabela 20. Resultado do Teste de Tukey para a variável altura da planta $(\mathrm{cm})$, em função dos sombreamentos e da altura do ambiente protegido (3,0m), da espécie A. fasciata, ESALQ-USP, Piracicaba, SP.

\begin{tabular}{lccccccccc}
\hline \multicolumn{1}{c}{ Tempo em dias } \\
Telas & 20 & 65 & 110 & 155 & 200 & 245 & 290 & 335 & 380 \\
\hline $18 \%$ & $6,0 \mathrm{a}$ & $9,7 \mathrm{~b}$ & $13,4 \mathrm{a}$ & $14,2 \mathrm{~b}$ & $24,0 \mathrm{~b}$ & $23,5 \mathrm{c}$ & $27,5 \mathrm{a}$ & $28,6 \mathrm{~b}$ & $31,1 \mathrm{~b}$ \\
$40 \%$ & $6,8 \mathrm{~b}$ & $10,7 \mathrm{ab}$ & $14,5 \mathrm{ab}$ & $17,9 \mathrm{ab}$ & $26,5 \mathrm{ab}$ & $25,3 \mathrm{bc}$ & $27,9 \mathrm{a}$ & $30,9 \mathrm{ab}$ & $34,5 \mathrm{a}$ \\
$60 \%$ & $6,8 \mathrm{~b}$ & $11,5 \mathrm{a}$ & $15,3 \mathrm{a}$ & $21,9 \mathrm{a}$ & $28,6 \mathrm{a}$ & $28,6 \mathrm{a}$ & $27,8 \mathrm{a}$ & $31,6 \mathrm{a}$ & $34,5 \mathrm{a}$ \\
$80 \%$ & $8,8 \mathrm{a}$ & $11,2 \mathrm{ab}$ & $14,2 \mathrm{a}$ & $17,7 \mathrm{~b}$ & $27,7 \mathrm{~b}$ & $28,6 \mathrm{a}$ & $29,0 \mathrm{a}$ & $30,2 \mathrm{ab}$ & $33,2 \mathrm{ab}$ \\
\hline
\end{tabular}

\subsubsection{Número de folhas}

Nas Tabelas 21 e 22, são apresentadas as medidas referentes ao número de folhas das plantas. As plantas sob as telas de sombreamento de 18 e $40 \%$ apresentaram um número de folhas com poucas diferenças entre si.

Nos tratamentos com telas de 60 e $80 \%$, observou-se um maior aumento do número de folhas, em ambos os ambientes estudados. Em ambientes com 
níveis elevados de sombreamento as plantas tendem a emitir maior número de folhas, a fim de garantir uma maior área exposta àluz, garantindo, assim, suas funções metabólicas, principalmente a fotossíntese, conforme explicam Carvalho \& Rocha (1999). Porém nos resultados encontrados observa-se que as plantas emitiram um maior número de folhas sob as telas com menores níveis de sombreamento, consequentemente as plantas sob as telas de $18 \mathrm{e}$ $40 \%$ de sombreamento emitiram maior número de folhas.

Acredita-se que esta discordância, entre os resultados encontrados neste trabalho e a literatura, seja em função da espécie estudada e do manejo experimental. Deve-se considerar que cada espécie apresenta o seu nível ótimo de sombreamento adequado ao seu desenvolvimento.

Tabela 21. Resultado do Teste de Tukey para a variável número de folhas, em função dos sombreamentos e da altura do ambiente protegido (3,5m), da espécie A. fasciata, ESALQ-USP, Piracicaba, SP.

\begin{tabular}{lccccccccc}
\hline \multicolumn{1}{c}{ Tempo em dias } \\
Telas & 20 & 65 & 110 & 155 & 200 & 245 & 290 & 335 & 380 \\
\hline $18 \%$ & $7,5 \mathrm{ab}$ & $6,7 \mathrm{~b}$ & $10,0 \mathrm{a}$ & $12,4 \mathrm{a}$ & $13,0 \mathrm{~b}$ & $12,9 \mathrm{ab}$ & $17,2 \mathrm{a}$ & $18,1 \mathrm{a}$ & $19,9 \mathrm{a}$ \\
$40 \%$ & $8,4 \mathrm{a}$ & $8,9 \mathrm{a}$ & $11,5 \mathrm{a}$ & $13,2 \mathrm{a}$ & $14,0 \mathrm{ab}$ & $14,1 \mathrm{a}$ & $16,3 \mathrm{a}$ & $17,0 \mathrm{a}$ & $19,4 \mathrm{a}$ \\
$60 \%$ & $7,0 \mathrm{~b}$ & $8,7 \mathrm{a}$ & $10,8 \mathrm{a}$ & $12,8 \mathrm{a}$ & $14,4 \mathrm{a}$ & $12,8 \mathrm{~b}$ & $13,9 \mathrm{~b}$ & $14,7 \mathrm{~b}$ & $16,3 \mathrm{~b}$ \\
$80 \%$ & $7,1 \mathrm{~b}$ & $8,5 \mathrm{a}$ & $11,6 \mathrm{a}$ & $14,1 \mathrm{a}$ & $13,0 \mathrm{~b}$ & $12,2 \mathrm{~b}$ & $13,5 \mathrm{~b}$ & $14,2 \mathrm{~b}$ & $16,2 \mathrm{~b}$ \\
\hline
\end{tabular}


Tabela 22. Resultado do Teste de Tukey para a variável número de folhas, em função dos sombreamentos e da altura do ambiente protegido $(3,0 \mathrm{~m})$, da espécie A. fasciata, ESALQ-USP, Piracicaba, SP.

\begin{tabular}{|c|c|c|c|c|c|c|c|c|c|}
\hline \multicolumn{10}{|c|}{ Tempo em dias } \\
\hline Telas & 20 & 65 & 110 & 155 & 200 & 245 & 290 & 335 & 380 \\
\hline $18 \%$ & $7,0 \mathrm{a}$ & $7,6 \mathrm{~b}$ & $8,9 b$ & $10,8 \mathrm{a}$ & $13,5 \mathrm{a}$ & $13,9 b$ & $17,2 \mathrm{a}$ & $18,2 \mathrm{a}$ & $20,4 a$ \\
\hline $40 \%$ & $7,4 \mathrm{a}$ & $9,3 a b$ & $11,7 \mathrm{a}$ & $12,0 \mathrm{a}$ & $14,0 \mathrm{a}$ & $15,4 \mathrm{a}$ & $16,0 \mathrm{a}$ & $17,4 \mathrm{a}$ & $19,0 \mathrm{a}$ \\
\hline $60 \%$ & $6,7 \mathrm{a}$ & $9,6 \mathrm{a}$ & $12,8 \mathrm{a}$ & $13,3 \mathrm{a}$ & $13,2 \mathrm{a}$ & $12,5 \mathrm{c}$ & $14,2 \mathrm{~b}$ & $14,9 \mathrm{a}$ & $16,1 \mathrm{~b}$ \\
\hline $80 \%$ & $6,4 a$ & $9,1 a b$ & $12,2 \mathrm{a}$ & $13,5 \mathrm{a}$ & $13,5 \mathrm{a}$ & $11,7 \mathrm{c}$ & $13,3 b$ & $14,0 \mathrm{~b}$ & $15,5 b$ \\
\hline
\end{tabular}

\subsubsection{Largura da folha}

As Tabelas 23 e 24 referem-se à largura das folhas das plantas. Conforme Carvalho \& Rocha (1999), as plantas submetidas a ambientes muito sombreados tendem a ficar com as folhas mais estreitas, porém mais longas. Isso ocorre para que haja aumento da sua área foliar, garantido assim, atividades metabólicas da planta, como fotossíntese e crescimento. Já as plantas que recebem grande quantidade de luz apresentam folhas com larguras menores, a fim de evitar que a insolação e a temperatura causem excesso de evaporação da água presente nas folhas.

De acordo com os resultados verificam-se que as diferenças começaram a partir do $65^{\circ}$ dia de cultivo das plantas sob as telas de sombreamento. Quando se analisa as plantas no $380^{\circ}$ dia verifica-se que os resultados são concordantes com a literatura, ou seja, plantas submetidas a uma maior intensidade luminosa apresentam folhas mais largas. 
Tabela 23. Resultado do Teste de Tukey para a variável krgura da folha $(\mathrm{cm})$, em função dos sombreamentos e da altura do ambiente protegido $(3,5 \mathrm{~m})$, da espécie A. fasciata, ESALQ-USP, Piracicaba, SP.

\begin{tabular}{lccccccccc}
\hline \multicolumn{1}{c}{ Telas } & 20 & 65 & 110 & 155 & 200 & 245 & 290 & 335 & 380 \\
\hline $18 \%$ & $1,2 \mathrm{a}$ & $2,5 \mathrm{~b}$ & $3,1 \mathrm{ab}$ & $3,6 \mathrm{ab}$ & $5,3 \mathrm{ab}$ & $6,7 \mathrm{ab}$ & $7,8 \mathrm{a}$ & $7,8 \mathrm{a}$ & $8,0 \mathrm{~b}$ \\
$40 \%$ & $1,0 \mathrm{a}$ & $2,9 \mathrm{a}$ & $3,4 \mathrm{a}$ & $4,0 \mathrm{a}$ & $5,8 \mathrm{a}$ & $7,1 \mathrm{a}$ & $7,9 \mathrm{a}$ & $7,8 \mathrm{a}$ & $8,5 \mathrm{a}$ \\
$60 \%$ & $1,1 \mathrm{a}$ & $2,8 \mathrm{ab}$ & $3,1 \mathrm{ab}$ & $3,7 \mathrm{ab}$ & $5,1 \mathrm{~b}$ & $6,2 \mathrm{~b}$ & $6,9 \mathrm{~b}$ & $7,1 \mathrm{~b}$ & $8,8 \mathrm{a}$ \\
$80 \%$ & $1,2 \mathrm{a}$ & $2,7 \mathrm{ab}$ & $2,8 \mathrm{~b}$ & $3,2 \mathrm{~b}$ & $4,4 \mathrm{c}$ & $6,4 \mathrm{bc}$ & $6,9 \mathrm{~b}$ & $7,2 \mathrm{~b}$ & $7,8 \mathrm{~b}$ \\
\hline
\end{tabular}

Tabela 24. Resultado do Teste de Tukey para a variável largura da folha $(\mathrm{cm})$, em função dos sombreamentos e da altura do ambiente protegido (3,0m), da espécie A. fasciata, ESALQ-USP, Piracicaba, SP.

\begin{tabular}{cccccccccc}
\hline \multicolumn{1}{c}{ Telas } & 20 & 65 & 110 & 155 & 200 & 245 & 290 & 335 & 380 \\
\hline $18 \%$ & $1,1 \mathrm{a}$ & $2,2 \mathrm{~b}$ & $2,7 \mathrm{a}$ & $3,5 \mathrm{~b}$ & $5,4 \mathrm{a}$ & $6,7 \mathrm{a}$ & $7,9 \mathrm{a}$ & $7,9 \mathrm{a}$ & $8,5 \mathrm{~b}$ \\
$40 \%$ & $1,1 \mathrm{a}$ & $2,7 \mathrm{a}$ & $3,5 \mathrm{c}$ & $4,1 \mathrm{a}$ & $5,7 \mathrm{a}$ & $7,1 \mathrm{a}$ & $8,1 \mathrm{a}$ & $8,2 \mathrm{a}$ & $9,0 \mathrm{a}$ \\
$60 \%$ & $1,1 \mathrm{a}$ & $2,0 \mathrm{~b}$ & $2,9 \mathrm{~b}$ & $3,6 \mathrm{~b}$ & $5,2 \mathrm{a}$ & $5,9 \mathrm{~b}$ & $7,4 \mathrm{~b}$ & $7,5 \mathrm{~b}$ & $8,7 \mathrm{~b}$ \\
$80 \%$ & $1,2 \mathrm{a}$ & $2,3 \mathrm{~b}$ & $2,7 \mathrm{~b}$ & $3,1 \mathrm{c}$ & $4,4 \mathrm{~b}$ & $6,9 \mathrm{a}$ & $7,1 \mathrm{a}$ & $7,3 \mathrm{~b}$ & $8,4 \mathrm{~b}$ \\
\hline
\end{tabular}

Médias seguidas pelas mesmas letras e na mesma coluna não diferem entre si, pelo Teste de Tukey ao nível de $5 \%$ de probabilidade.

4.2.1.4 Diâmetro da roseta

Para a variável diâmetro da roseta, as Tabelas 25 e 26 mostram as maiores diferenças nas telas de 60 e $80 \%$ de sombreamento. Plantas submetidas a áreas sombreadas tendem a ter sua área foliar aumentada; sendo assim, as plantas destes tratamentos possuem o comprimento das folhas muito 
superior aos encontrados para a mesma variável, sob as telas de sombreamento de 18 e $40 \%$. Esse maior diâmetro da roseta foi observado nos dois ambientes.

Foi observado pelo Teste de Tukey que, não houve diferença estatística entre as plantas sob as telas de 18 e $40 \%$ e entre as telas de 60 e $80 \%$ para o ambiente com altura $3,5 \mathrm{~m}$. Houve uma diferença quando comparado as telas de 18 e $40 \%$ com as de 60 e $80 \%$.

Esses resultados são concordantes com os encontrados por Carvalho \& Rocha (1999).

Tabela 25. Resultado do Teste de Tukey para a variável diâmetro da roseta $(\mathrm{cm})$, em função dos sombreamentos e da altura do ambiente protegido $(3,5 \mathrm{~m})$, da espécie $A$. fasciata, ESALQ-USP, Piracicaba, SP.

\begin{tabular}{lccccccccc}
\hline \multicolumn{1}{c}{ Tempo em dias } \\
Telas & 20 & 65 & 110 & 155 & 200 & 245 & 290 & 335 & 380 \\
\hline $18 \%$ & $20,7 \mathrm{ab}$ & $24,3 \mathrm{a}$ & $26,6 \mathrm{a}$ & $25,7 \mathrm{~b}$ & $37,6 \mathrm{c}$ & $39,4 \mathrm{~b}$ & $44,2 \mathrm{~b}$ & $43,3 \mathrm{~b}$ & $44,1 \mathrm{~b}$ \\
$40 \%$ & $21,1 \mathrm{a}$ & $26,3 \mathrm{a}$ & $27,2 \mathrm{a}$ & $29,0 \mathrm{~b}$ & $46,0 \mathrm{~b}$ & $44,5 \mathrm{~b}$ & $46,9 \mathrm{~b}$ & $47,1 \mathrm{~b}$ & $47,3 \mathrm{~b}$ \\
$60 \%$ & $17,7 \mathrm{c}$ & $25,0 \mathrm{a}$ & $27,5 \mathrm{a}$ & $35,1 \mathrm{a}$ & $58,0 \mathrm{a}$ & $63,6 \mathrm{a}$ & $68,7 \mathrm{a}$ & $68,0 \mathrm{a}$ & $67,4 \mathrm{a}$ \\
$80 \%$ & $18,9 \mathrm{bc}$ & 24,7 a & $27,4 \mathrm{a}$ & $33,8 \mathrm{a}$ & $57,5 \mathrm{a}$ & 61,2 a & 62,7 a & $63,2 \mathrm{a}$ & $63,2 \mathrm{a}$ \\
\hline
\end{tabular}


Tabela 26. Resultado do Teste de Tukey para a variável diâmetro da roseta $(\mathrm{cm})$, em função dos sombreamentos e da altura do ambiente protegido $(3,0 \mathrm{~m})$, da espécie $A$. fasciata, ESALQ-USP, Piracicaba, SP.

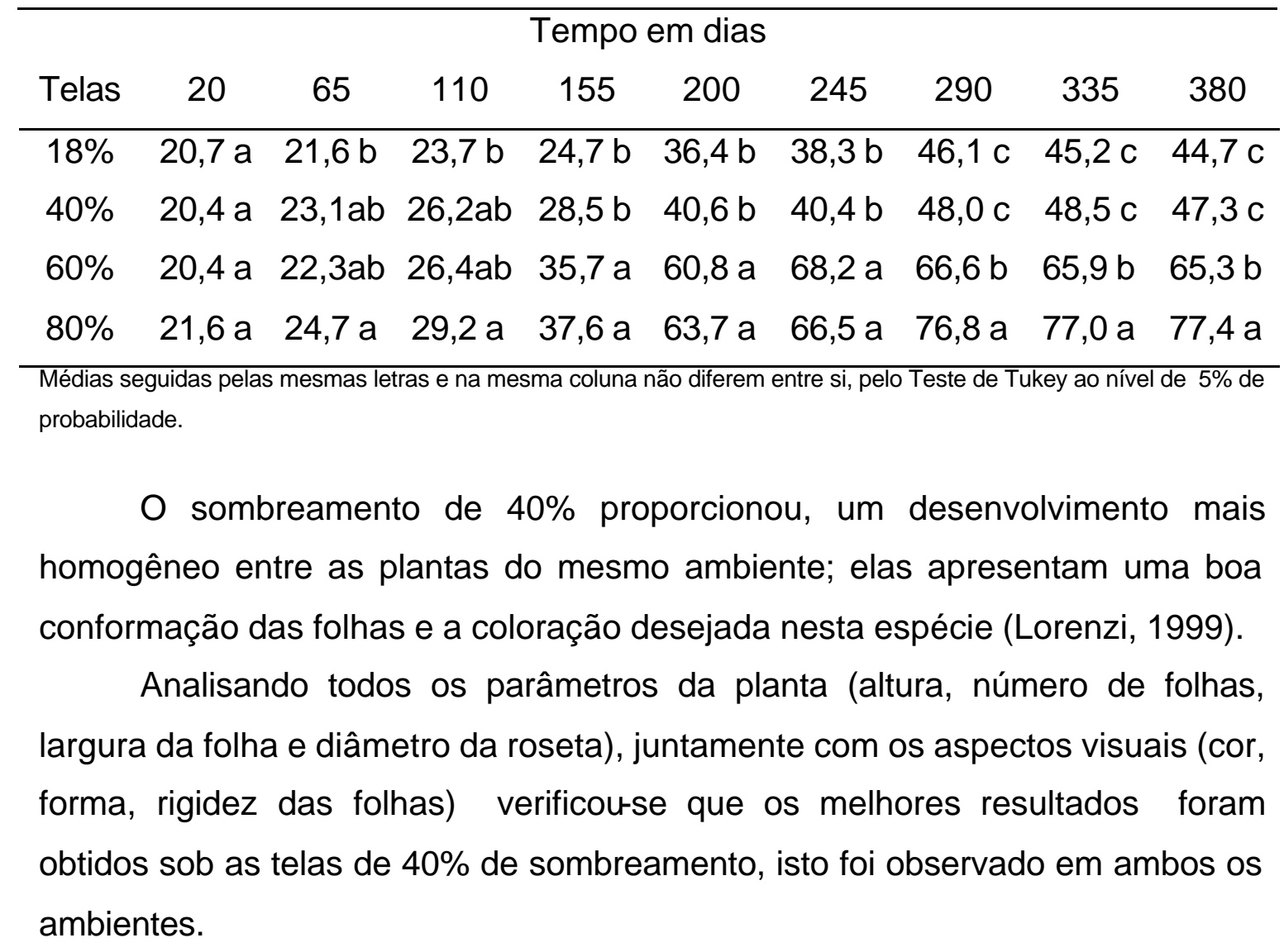

\subsubsection{Guzmania lingulata}

\subsubsection{Altura das plantas}

Nas Tabelas 27 e 28, são apresentados os valores médios da altura das plantas nos ambientes de 3,0 e 3,5m de altura, realizados ao longo do ciclo de cultivo, $380^{\circ}$ dia. 
Em virtude do excesso de luz incidente nas plantas submetidas às telas de $18 \%$ de sombreamento, elas apresentam uma redução na altura, causada por queimaduras drásticas, que acarretaram até a morte de algumas das plantas. Isso ocorreu nos dois ambientes estudados.

Observa-se pelas Tabelas 27 e 28 que as plantas sob as telas de sombreamento de $18 \%$ apresentaram diferenças significativas quando comparadas com as plantas das demais telas. As plantas sob as telas de 40, 60 e $80 \%$ de sombreamento não apresentaram diferenças significativas entre si para ambos os ambientes estudados. Os maiores valores de altura das plantas foi observado sob as telas de $40 \%$.

Esta espécie não sofreu o efeito do estiolamento, pois são plantas que requerem uma menor quantidade de luz. As plantas sob as telas de 40, $60 \mathrm{e}$ $80 \%$ apresentaram uma coloração característica da espécie, como folhas verdes escuras (Lorenzi, 1999).

Tabela 27. Resultado do Teste de Tukey para a variável altura da planta $(\mathrm{cm})$, em função dos sombreamentos e da altura do ambiente protegido (3,5m), da espécie G. lingulata, ESALQ-USP, Piracicaba, SP.

\begin{tabular}{lccccccccc}
\hline \multicolumn{1}{c}{ Telas } & 20 & 65 & 110 & 155 & 200 & 245 & 290 & 335 & 380 \\
\hline $18 \%$ & $5,4 \mathrm{c}$ & $8,3 \mathrm{~b}$ & $10,2 \mathrm{c}$ & $10,6 \mathrm{~b}$ & $12,4 \mathrm{~b}$ & $17,0 \mathrm{a}$ & $19,3 \mathrm{~b}$ & $20,3 \mathrm{c}$ & $21,5 \mathrm{~b}$ \\
$40 \%$ & $6,2 \mathrm{bc}$ & $9,7 \mathrm{ab}$ & $11,2 \mathrm{bc}$ & $11,7 \mathrm{~b}$ & $14,7 \mathrm{a}$ & $18,8 \mathrm{a}$ & $20,9 \mathrm{ab}$ & $22,4 \mathrm{ab}$ & $24,4 \mathrm{a}$ \\
$60 \%$ & $6,8 \mathrm{ab}$ & $9,8 \mathrm{a}$ & $12,7 \mathrm{ab}$ & $13,0 \mathrm{a}$ & $15,7 \mathrm{a}$ & $18,9 \mathrm{a}$ & $21,1 \mathrm{a}$ & $22,7 \mathrm{a}$ & $23,2 \mathrm{a}$ \\
$80 \%$ & $7,7 \mathrm{a}$ & $9,8 \mathrm{a}$ & $13,1 \mathrm{a}$ & $13,8 \mathrm{a}$ & $15,8 \mathrm{a}$ & $17,6 \mathrm{a}$ & $19,9 \mathrm{ab}$ & $20,9 \mathrm{bc}$ & $22,2 \mathrm{a}$ \\
\hline
\end{tabular}


Tabela 28. Resultado do Teste de Tukey para a variável altura da planta $(\mathrm{cm})$, em função dos sombreamentos e da altura do ambiente protegido (3,0m), da espécie G. lingulata, ESALQ-USP, Piracicaba, SP.

\begin{tabular}{lccccccccc}
\hline \multicolumn{1}{c}{ Telas } & 20 & 65 & 110 & 155 & 200 & 245 & 290 & 335 & 380 \\
\hline $18 \%$ & $7,1 \mathrm{ab}$ & $8,9 \mathrm{a}$ & $11,2 \mathrm{~b}$ & $10,7 \mathrm{~b}$ & $11,6 \mathrm{c}$ & $14,5 \mathrm{~b}$ & $17,0 \mathrm{~b}$ & $17,7 \mathrm{~b}$ & $18,9 \mathrm{c}$ \\
$40 \%$ & $6,0 \mathrm{~b}$ & $8,0 \mathrm{a}$ & $11,1 \mathrm{~b}$ & $12,2 \mathrm{ab}$ & $16,9 \mathrm{a}$ & $18,2 \mathrm{a}$ & $22,1 \mathrm{a}$ & $23,3 \mathrm{a}$ & $24,9 \mathrm{a}$ \\
$60 \%$ & $7,9 \mathrm{a}$ & $8,7 \mathrm{a}$ & $11,4 \mathrm{ab}$ & $11,9 \mathrm{ab}$ & $14,4 \mathrm{~b}$ & $17,6 \mathrm{a}$ & $20,5 \mathrm{a}$ & $21,9 \mathrm{a}$ & $24,3 \mathrm{a}$ \\
$80 \%$ & $7,5 \mathrm{a}$ & $7,8 \mathrm{a}$ & $13,0 \mathrm{a}$ & $13,4 \mathrm{a}$ & $15,9 \mathrm{ab}$ & $18,8 \mathrm{a}$ & $21,5 \mathrm{a}$ & $22,3 \mathrm{a}$ & $24,2 \mathrm{a}$ \\
\hline
\end{tabular}

\subsubsection{Número de folhas}

Foi observado nas Tabelas 29 e 30, pela análise estatística referente ao $380^{\circ}$ dia de cultivo das plantas, sob as telas de sombreamento, que a tela de $18 \%$ proporcionou elevada incidência de luz sobre as plantas, causando inicialmente um amarelamento das folhas e posteriormente queimaduras graves, diminuindo assim o número médio de folhas.

Nos tratamentos sob as telas de 40,60 e $80 \%$ observou-se que as plantas apresentaram diferenças significativas entre si para a altura de $3,5 \mathrm{~m}$, entre estas telas, a que apresentou uma maior média no número de folhas foi a tela com $40 \%$ de sombreamento. Quando analisamos o ambiente com altura de $3,0 \mathrm{~m}$ para estas mesmas telas (40,60 e 80\%) verifica-se que não houve diferença significativa entre as telas de 40 e $60 \%$, neste ambiente também verifica-se que a tela de $40 \%$ apresentou as maiores médias para o número de folhas. 
Tabela 29. Resultado do Teste de Tukey para a variável número de folhas, em função dos sombreamentos e da altura do ambiente protegido $(3,5 \mathrm{~m})$, da espécie G. lingulata, ESALQ-USP, Piracicaba, SP.

\begin{tabular}{lccccccccc}
\hline \multicolumn{1}{c}{ Telas } & 20 & 65 & 110 & 155 & 200 & 245 & 290 & 335 & 380 \\
\hline $18 \%$ & $6,9 a b$ & $7,6 \mathrm{a}$ & $10,4 \mathrm{a}$ & $11,6 \mathrm{a}$ & $13,1 \mathrm{a}$ & $14,0 \mathrm{ab}$ & $14,3 \mathrm{a}$ & $15,2 \mathrm{a}$ & $17,2 \mathrm{~b}$ \\
$40 \%$ & $6,4 \mathrm{~b}$ & $7,9 \mathrm{a}$ & $9,5 \mathrm{a}$ & $11,0 \mathrm{a}$ & $12,8 \mathrm{a}$ & $15,5 \mathrm{a}$ & $16,1 \mathrm{a}$ & $17,4 \mathrm{a}$ & $20,1 \mathrm{a}$ \\
$60 \%$ & $7,1 \mathrm{a}$ & $8,5 \mathrm{a}$ & $10,9 \mathrm{a}$ & $11,3 \mathrm{a}$ & $13,2 \mathrm{a}$ & $14,4 \mathrm{a}$ & $16,4 \mathrm{a}$ & $17,3 \mathrm{a}$ & $17,2 \mathrm{~b}$ \\
$80 \%$ & $7,6 \mathrm{a}$ & $8,5 \mathrm{a}$ & $10,7 \mathrm{a}$ & $10,4 \mathrm{a}$ & $12,2 \mathrm{a}$ & $13,7 \mathrm{~b}$ & $14,4 \mathrm{~b}$ & $15,6 \mathrm{a}$ & $18,7 \mathrm{c}$ \\
\hline
\end{tabular}

Tabela 30. Resultado do Teste de Tukey para a variável número de folhas, em função dos sombreamentos e da altura do ambiente protegido (3,0m), da espécie G. lingulata, ESALQ-USP, Piracicaba, SP.

\begin{tabular}{lccccccccc}
\hline \multicolumn{1}{c}{ Telas } & 20 & 65 & 110 & 155 & 200 & 245 & 290 & 335 & 380 \\
\hline $18 \%$ & $6,7 \mathrm{a}$ & $7,3 \mathrm{a}$ & $9,2 \mathrm{~b}$ & $10,1 \mathrm{~b}$ & $10,9 \mathrm{~b}$ & $12,2 \mathrm{c}$ & $11,7 \mathrm{~b}$ & $12,5 \mathrm{c}$ & $14,8 \mathrm{c}$ \\
$40 \%$ & $6,9 \mathrm{a}$ & $7,9 \mathrm{a}$ & $10,9 \mathrm{a}$ & $12,3 \mathrm{a}$ & $14,5 \mathrm{a}$ & $16,1 \mathrm{a}$ & $17,5 \mathrm{a}$ & $18,9 \mathrm{a}$ & $22,7 \mathrm{a}$ \\
$60 \%$ & $6,8 \mathrm{a}$ & $7,0 \mathrm{a}$ & $11,3 \mathrm{a}$ & $11,6 \mathrm{ab}$ & $12,4 \mathrm{ab}$ & $15,1 \mathrm{ab}$ & $15,4 \mathrm{a}$ & $18,0 \mathrm{ab}$ & $21,4 \mathrm{a}$ \\
$80 \%$ & $6,1 \mathrm{a}$ & $7,0 \mathrm{a}$ & $10,2 \mathrm{ab}$ & $11,3 \mathrm{ab}$ & $11,9 \mathrm{~b}$ & $12,7 \mathrm{bc}$ & $15,3 \mathrm{a}$ & $16,1 \mathrm{~b}$ & $17,9 \mathrm{~b}$ \\
\hline
\end{tabular}

\subsubsection{Largura das folhas}

Nas Tabelas 31 e 32, são apresentados os valores médios referentes à largura das folhas; observourse que as plantas sob as telas de $18 \%$ de sombreamento possuem uma menor largura das folhas, quando comparadas ì de outros níveis de sombreamento, devido à alta incidência de radiação solar sobre as plantas. $O$ fato determina que as plantas reduzam sua área foliar, para 
evitar, assim, a evaporação da água contida nas folhas (Carvalho \& Rocha, 1999).

Para esta variável observa-se pelas tabelas que as diferenças entre as telas surgiram a partira do $115^{\circ}$ dia de cultivo das plantas sob as telas; analisando a última coleta de dados, referente ao $380^{\circ}$ dia, observa-se que para ambos os ambientes estudados as telas de 40 e $60 \%$ de sombreamento não apresentaram diferenças estatísticas entre si, o mesmo ocorreu quando comparadas as telas de 18 e $80 \%$. Dentre as telas estudadas as que proporcionaram maior largura de folha foram as de 40 e $60 \%$

A tela que proporcionou às plantas as menores larguras das folhas foi a com $18 \%$ de sombreamento, isso pode ser explicado pelo fato destas plantas não tolerarem alta incidência de luz, fazendo com que as plantas percam maiores quantidades de água, prejudicando o seu desenvolvimento.

Tabela 31. Resultado do Teste de Tukey para a variável largura da folha $(\mathrm{cm})$, em função dos sombreamentos e da altura do ambiente protegido (3,5m), da espécie G. lingulata, ESALQ-USP, Piracicaba, SP.

\begin{tabular}{cccccccccc}
\hline \multicolumn{1}{c}{ Tempo em dias } \\
Telas & 20 & 65 & 110 & 155 & 200 & 245 & 290 & 335 & 380 \\
\hline $18 \%$ & $0,9 \mathrm{a}$ & $1,1 \mathrm{a}$ & $1,4 \mathrm{a}$ & $1,6 \mathrm{a}$ & $1,8 \mathrm{~b}$ & $2,4 \mathrm{~b}$ & $2,8 \mathrm{a}$ & $3,0 \mathrm{~b}$ & $3,3 \mathrm{~b}$ \\
$40 \%$ & $0,9 \mathrm{a}$ & $1,3 \mathrm{a}$ & $1,4 \mathrm{a}$ & $1,9 \mathrm{a}$ & $2,3 \mathrm{a}$ & $3,1 \mathrm{a}$ & $3,4 \mathrm{a}$ & $3,4 \mathrm{a}$ & $3,9 \mathrm{a}$ \\
$60 \%$ & $0,9 \mathrm{a}$ & $1,3 \mathrm{a}$ & $1,6 \mathrm{a}$ & $1,9 \mathrm{a}$ & $2,3 \mathrm{a}$ & $3,0 \mathrm{a}$ & $3,5 \mathrm{a}$ & $3,5 \mathrm{a}$ & $3,9 \mathrm{a}$ \\
$80 \%$ & $0,9 \mathrm{a}$ & $1,2 \mathrm{a}$ & $1,3 \mathrm{a}$ & $1,7 \mathrm{ab}$ & $2,0 \mathrm{ab}$ & $2,5 \mathrm{~b}$ & $3,0 \mathrm{~b}$ & $3,0 \mathrm{~b}$ & $3,3 \mathrm{~b}$ \\
\hline
\end{tabular}

Médias seguidas pelas mesmas letras e na mesma coluna não diferem entre si, pelo Teste de Tukey ao nível de 5\% de probabilidade. 
Tabela 32. Resultado do Teste de Tukey para a largura da folha $(\mathrm{cm})$, em função dos sombreamentos e da altura do ambiente protegido (3,0m), da espécie G. lingulata, ESALQ-USP, Piracicaba, SP.

\begin{tabular}{lccccccccc}
\hline \multicolumn{1}{c}{ Telas } & 20 & 65 & 110 & 155 & 200 & 245 & 290 & 335 & 380 \\
\hline $18 \%$ & $1,0 \mathrm{a}$ & $1,2 \mathrm{a}$ & $1,4 \mathrm{a}$ & $1,6 \mathrm{~b}$ & $1,7 \mathrm{~b}$ & $2,1 \mathrm{~b}$ & $2,6 \mathrm{~b}$ & $2,8 \mathrm{~b}$ & $3,0 \mathrm{~b}$ \\
$40 \%$ & $1,0 \mathrm{a}$ & $1,3 \mathrm{a}$ & $1,7 \mathrm{a}$ & $2,0 \mathrm{a}$ & $2,4 \mathrm{a}$ & $3,1 \mathrm{a}$ & $3,9 \mathrm{a}$ & $3,9 \mathrm{a}$ & $4,0 \mathrm{a}$ \\
$60 \%$ & $1,0 \mathrm{a}$ & $1,2 \mathrm{a}$ & $1,4 \mathrm{a}$ & $1,8 \mathrm{ab}$ & $2,2 \mathrm{a}$ & $3,0 \mathrm{a}$ & $3,5 \mathrm{a}$ & $3,5 \mathrm{a}$ & $4,0 \mathrm{a}$ \\
$80 \%$ & $0,9 \mathrm{a}$ & $1,2 \mathrm{a}$ & $1,6 \mathrm{a}$ & $1,9 \mathrm{ab}$ & $2,2 \mathrm{a}$ & $2,9 \mathrm{a}$ & $3,4 \mathrm{a}$ & $3,4 \mathrm{a}$ & $3,4 \mathrm{~b}$ \\
\hline
\end{tabular}

\subsubsection{Diâmetro da roseta}

Como já colocado anteriormente, plantas submetidas a áreas sob as telas de 60 e $80 \%$ de sombreamento tendem a ter sua área foliar aumentada, devido à redução da luminosidade que consequentemente promovera o alongamento das folhas para a captação de maior quantidade de luz garantindo assim os seus processos fotossintéticos (Carvalho \& Rocha, 1999). .

Nas Tabelas 33 e 34 verifica-se que as plantas, aos 380 dias de cultivo sob as telas de sombreamento, apresentaram uma diferença significativa entre a tela de $18 \%$ quando comparada com as demais telas, isso ocorreu em ambos os ambientes. A tela de $18 \%$ apresentou as menores médias para o diâmetro da roseta; as telas de 40, 60 e $80 \%$ não diferiram entre si.

Plantas submetidas a um maior nível de sombreamento tendem a ter suas folhas mais compridas, resultado que converge para os encontrados por Carvalho \& Rocha (1999). 
Tabela 33. Resultado do Teste de Tukey para a variável diâmetro da roseta $(\mathrm{cm})$, em função dos sombreamentos e da altura do ambiente protegido (3,5m), da espécie G. lingulata, ESALQ-USP, Piracicaba, SP.

\begin{tabular}{|c|c|c|c|c|c|c|c|c|c|}
\hline \multicolumn{10}{|c|}{ Tempo em dias } \\
\hline Telas & 20 & 65 & 110 & 155 & 200 & 245 & 290 & 335 & 380 \\
\hline $18 \%$ & $20,5 b$ & $23,1 \mathrm{a}$ & $25,7 a$ & $24,3 b$ & $21,8 b$ & $27,4 \mathrm{~b}$ & $30,7 \mathrm{~b}$ & $32,3 b$ & $34,1 \mathrm{~b}$ \\
\hline $40 \%$ & $23,3 \mathrm{a}$ & $25,5 \mathrm{a}$ & $27,2 \mathrm{a}$ & $28,2 \mathrm{a}$ & $26,9 \mathrm{a}$ & $33,0 \mathrm{a}$ & $35,5 \mathrm{a}$ & $37,5 \mathrm{a}$ & $40,0 a$ \\
\hline $60 \%$ & $21,5 a b$ & $24,3 \mathrm{a}$ & $27,4 \mathrm{a}$ & $26,8 a b$ & $29,9 a$ & $35,4 \mathrm{a}$ & $38,0 \mathrm{a}$ & $39,4 a$ & $42,2 \mathrm{a}$ \\
\hline $80 \%$ & $22,4 a b$ & $25,1 \mathrm{a}$ & $26,7 \mathrm{a}$ & $30,0 \mathrm{a}$ & $29,6 \mathrm{a}$ & $33,6 a$ & $37,1 \mathrm{a}$ & $38,6 \mathrm{a}$ & $42,2 \mathrm{a}$ \\
\hline
\end{tabular}

Tabela 34. Resultado do Teste de Tukey para a variável diâmetro da roseta (cm), em função dos sombreamentos e da altura do ambiente protegido (3,0m), da espécie G. lingulata, ESALQ-USP, Piracicaba, SP.

\begin{tabular}{lccccccccc}
\hline \multicolumn{1}{c}{ Telas } & 20 & 65 & 110 & 155 & 200 & 245 & 290 & 335 & 380 \\
\hline $18 \%$ & 20,8 a & 25,2 a & 27,5 a & 26,1 a & 21,5 b & 25,5 b & 29,6 b & 30,0 b & 31,2 b \\
$40 \%$ & 20,9 a & $23,5 \mathrm{ab}$ & 27,1 a & 25,7 a & 27,4 a & 34,7 a & 40,2 a & 41,2 a & 43,3 a \\
$60 \%$ & 21,4 a & 24,0 b & 27,0 a & 27,3 a & 26,6 a & 34,1 a & 42,1 a & 44,6 a & 46,8 a \\
$80 \%$ & 21,1 a & 22,7 b & 29,3 a & 28,6 a & 29,9 a & 36,9 a & 43,8 a & 45,1 a & 48,6 a \\
\hline
\end{tabular}

A espécie G. lingulata mostrou-se mais sensível à radiação solar, visto que as plantas dessa espécie quando submetidas àtela de $18 \%$ apresentaram queimaduras graves nas folhas (Figura 17), já as plantas da espécie $A$. fasciata sob a mesma tela apresentou apenas uma descoloração nas folhas, não sendo foi observadas queimaduras. 


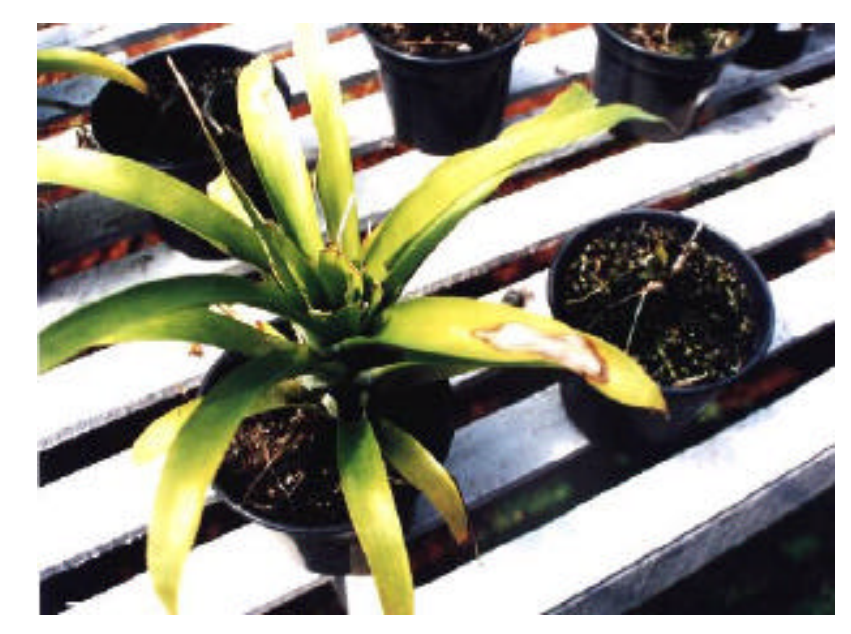

Figura 17. Planta da espécie $G$. lingulata com queimaduras nas folhas e ao lado vaso com a planta já morta, foto referente aos 380 dias de cultivo sob a tela de sombreamento de $18 \%$,.

Quando analisourse os dados das telas que proporcionaram um maior nível de sombra (60 e $80 \%$ ), as plantas da espécie $A$. fasciata apresentaram folhas mais compridas e estreitas do que as da espécie $G$. lingulata.

Concordando com Carvalho \& Rocha (1999), esse trabalho confirma que as bromélias são realmente dependentes da quantidade de radiação solar que incide sobre elas, a qual determina a sua coloração, o tamanho e o formato das plantas.

As Figuras 18 e 19 mostram as diferenças visualizadas nas plantas, em função dos níveis de sombreamento. Observou-se que as plantas de $A$. fasciata, submetidas a um maior nível de sombreamento - 60 e $80 \%$-, apresentaram folhas mais alongadas, com coloração mais escura. Já as plantas de $G$. lingulata apresentam menores diferenças quanto à coloração e ao tamanho, nas telas com maior sombreamento. 


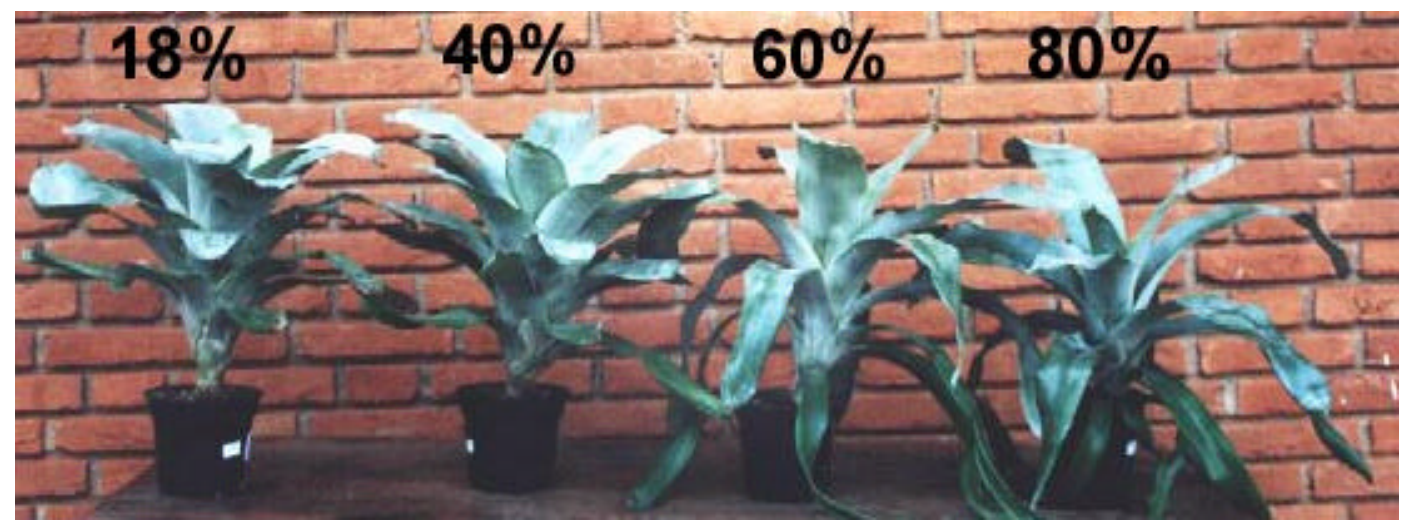

Figura 18 - Plantas de A. fasciata submetidas a diferentes níveis de sombreamento, ao longo do ciclo de cultivo de 380 dias.

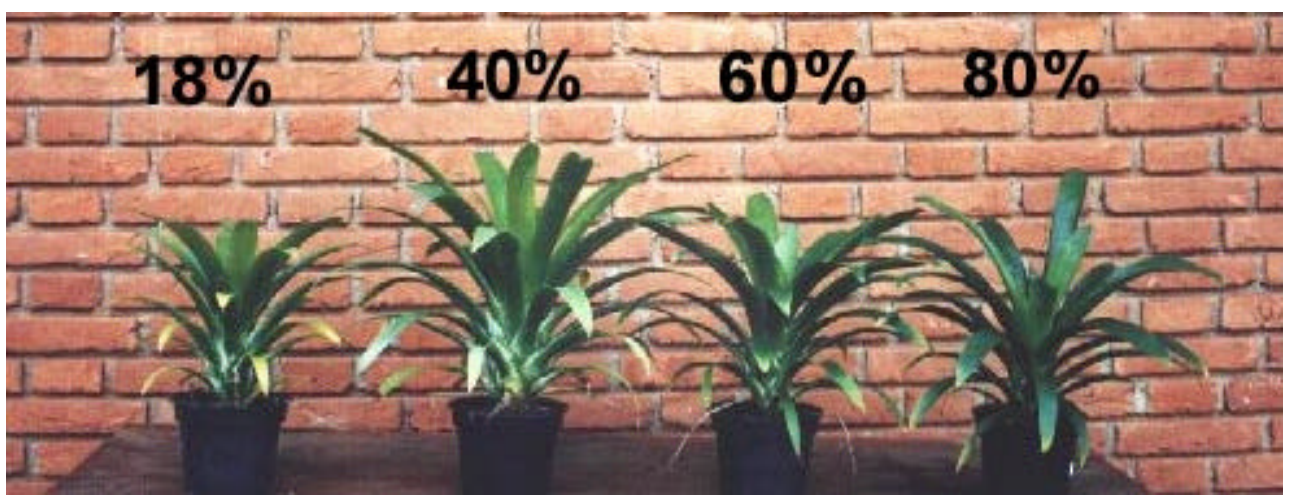

Figura 19 - Plantas de G. lingulata submetidas a diferentes níveis de sombreamento, ao longo do ciclo de cultivo de 380 dias.

Analisando os dados microclimáticos e os parâmetros de desenvolvimento das plantas, observou-se que o aumento de $0,5 \mathrm{~m}$ na altura do ambiente protegido não foi suficiente para causar alterações æ̀s plantas. As variações no desenvolvimento destas plantas ocorreram em função das diferentes telas de sombreamento utilizadas neste estudo. 
Para a espécie $A$. fasciata o maior desenvolvimento para as variáveis altura, número de folhas e largura da folha foi verificado sob a tela de $40 \%$, os valores de diâmetro da roseta foram maiores nas telas de 60 e $80 \%$, porém este maior desenvolvimento não traduz uma planta com melhores características para esta variável, pela análise visual as plantas com um diâmetro de roseta adequado são as que estão sob as telas de $40 \%$ de sombreamento, tendo em média de 26 a $27 \mathrm{~cm}$.

Em função dos aspectos estudados pode-se verificar que as bromélias são plantas altamente influenciadas pelo nível de luminosidade que as mesmas são submetidas.

Analisando os mesmos dados para a espécie G. lingulata as plantas sob as telas de $40 \%$ foram as que apresentaram um melhor desenvolvimento, apresentaram folhas com uma coloração verde escura que é a cor característica da espécie (Lorenzi, 1999).

\subsection{Considerações finais}

A ausência de informações técnico-científicas sobre o cultivo de bromélias foi uma das grandes barreiras encontradas nesta pesquisa.

Verificou-se que as informações existentes são oriundas dos cultivos comerciais, o que por sua vez, não são divulgados, impedindo o acesso æ̀ mesmas.

Por serem plantas ornamentais de grande importância comercial, estudos relacionados com a produção de bromélias devem ser conduzidas de forma a esclarecer os gargalos existentes nos mais diferentes níveis da produção.

Em sistemas de produção mais avançados verifica-se que as tomadas de decisões são realizadas empiricamente em função da experimentação de campo. Mesmo sendo um cultivo comercial, a inexistência de padrões de excelência, dificulta a avaliação dos parâmetros da planta adulta. 
Em função desses fatores, acredita-se que os dados oriundos dessa pesquisa, possam fornecer informações úteis aos produtores de bromélias do país.

Para as condições em que foram realizadas este trabalho verificou-se que para as espécies estudadas, $A$. fasciata e $G$. lingulata, o melhor nível de sombreamento foi proporcionado pela tela de $40 \%$.

\subsection{Sugestões para novas pesquisas}

Diante da ausência de informações para o cultivo comercial de bromélias verificourse a existência de grandes lacunas em pesquisa e desenvolvimento na área de controle do ambiente para esta cultura. Em função disso, sugere-se novas pesquisas com os:

- Estudo dos níveis de sombreamento intermediários entre as telas com níveis de sombreamento de 40 e $60 \%$;

- Avaliação da influência de diferentes alturas da telas no sombreamento das plantas;

- Estabelecimento de padrões ideais de comercialização em função das características da planta;

- Avaliação as exigências de outras espécies de bromélias em relação ao ambiente de produção. 


\section{CONCLUSÕES}

Baseando-se nas condições em que foram realizadas esta pesquisa podese concluir que:

- A variação da altura dos ambientes protegidos estudados (3,5 e 3,5m) não apresentaram diferenças estatísticas significativas nas variáveis do ambiente ( temperatura do ar, umidade relativa do ar, temperatura de globo negro, carga térmica de radiação, radiação solar global e intensidade luminosa);

- Quando se analisou o ambiente térmico sob as telas de sombreamento verificou que houve diferenças estatísticas significativas nas variáveis que foram estudadas neste microambiente (temperatura do ar, umidade relativa, temperatura de globo negro e intensidade luminosa);

- Para as espécies estudadas, $A$. fasciata e G. lingulata, a tela de sombreamento que proporcionou 0 melhor desenvolvimento, diferenciando-se estatisticamente das demais em função dos parâmetros (altura da planta, número de folhas, largura da folha e diâmetro da roseta), foi a tela com nível de $40 \%$. 


\section{REFERÊNCIAS BIBLIOGRÁFICAS}

ABREU, P.G. de; ABREU, V.M.N.; MAZZUCO, H. Uso do resfriamento evaporativo (adiabático) na criação de frangos de corte. Concórdia: EMBRAPA,CNPSA, 1999. 51p. (EMBRAPA. CNPSA, Documentos, 59).

ALPI, A., TOGNONI, F. Cultivo en inverdadero. 3.ed. Madrid: Mundi-Prensa, 1991. 347p.

ANDRADE, F.S.A. de; DEMATTÊ, M.E.S.P. Estudo sobre produção e comercialização de bromélias nas regiões Sul e Sudeste do Brasil. Revista Brasileira de Horticultura Ornamental, v.5, p.97-110, 1999.

ANDRIOLO, L.J. Fisiologia da produção de hortaliças em ambiente protegido. Horticultura Brasileira, v.18. p. 26-33, jul. 2000. Suplemento.

ARRUDA, S.T.; OLIVETTE, M.P.A.; CASTRO, C.E.F. de. Diagnóstico da floricultura do Estado de São Paulo. Revista de Horticultura Brasileira Ornamental, v.2. p.1-18, 1996.

ATARASSI, R.T. Modelagem do microclima em ambiente protegido. Piracicaba, 1999. 96p. Dissertação (Mestrado) - Escola Superior de Agricultura "Luiz de Queiroz", Universidade de São Paulo.

BACCARI JUNIOR, F. Adaptação de sistemas de manejo na produção de leite em clima quente. SIMPÓSIO BRASILEIRO DE AMBIÊNCIA NA PRODUÇÃO DE LEITE, 1, Piracicaba, 1998. Anais. Piracicaba: FEALQ, 1998. p.24-67.

BAÊTA, F.C.; SOUZA, C.F. Ambiência em edificações rurais: conforto animal. Viçosa: UFV, 1997. 246p. 
BLISKA, JR.A.; HONÓRIO, S.L. Cartilha tecnológica de plasticultura e estufa. Campinas: UNICAMP, 1996. 85p.

BOND, T.E; KELLY. C.E. The globe thermometer in agricultural research. Agricultural Engineering, v.36, p.251-260, 1955.

BRUN, R.; LAGIER, I. A new greenhouse structure adapted to mediterranean growing. Acta Horticulturae, n. 170. p.37-46, 1985.

BURIOL, G.A.; SCHNEIDER, F.M.; ESTEFANEL, V.; ANDRIOLO, J.L.; MEDEIROS, S.L.P. Modificações na temperatura mínima do ar causada por estufas de polietileno transparente de baixa densidade. Revista Brasileira de Agrometeorologia, v.1, p.43-49, 1993.

BURIOL, G. A. ; HELDWEIN, A. B.; STRECK, N. A.; SCHNEIDER, F. M.; ESTEFANEL, V.; DALMAGO, G. A. Gradiente vertical de temperatura do ar no interior de estufas plásticas. In: CONGRESSO BRASILEIRO DE AGROMETEOROLOGIA, 10, Piracicaba, SP, 1997. Anais. Piracicaba: Sociedade Brasileira de Agrometeorologia. p. 471-472,1997. (13 a 18 jul. 1997).

BURIOL, G.A.; RIGHI, E.Z, SCHNEIDER, F.M.; STRECK, N.A.; HELDWEIN, A.B.; ESTEFANEL, V. Modificação da umidade relativa do ar pelo uso e manejo da estufa plástica. Revista Brasileira de Agrometeorologia, v.8, n. 1, p.11-18, 2000.

CAMACHO, M. J.; ASSIS, F.N. de; MARTINS, S.R.; MENDEZ, M.E.G. Avaliação de elementos meteorológicos em estufa plástica em Pelotas, RS. Revista Brasileira de Agrometeorologia, v.3, p.19-24, 1995.

CAMARGO, F.T., MELHEM, T.S., SILVA,I.J.O.; Evaluation of environment control systems in plastic greenhouse in tropical coutries (compact disc). In: MEMORIAL CIGR WORLD CONGRESS, 14., Tsukuba, 2000,.Tsukuba: CIGR, 2000.

CARVALHO, L.C.; ALMEIDA, D.R. de.; ROCHA, C.F.D. Phenotypic response of Neoregelia johannis (bromeliaceae) dependent on light intensity reaching the plant microhabitat. Selbyana, v. 19, n. 2, p.240-244, 1998. 
CARVALHO, L.C.; ROCHA, C.F.D. da. Forma da bromélia depende da luz. Ciência Hoje, v 26, n.155, p.72-74, 1999.

CERMEÑO, Z.S. Construccion de invernaderos. Madrid: Mundi-Prensa, 1994. 445p.

ESTRELAS tropicais, Globo Rural. n.193, p.50-54, nov. 2001.

FARIA JUNIOR. M. J. A.; SOUZA. R. A. R.; HORA. R. C. Cultivo de alface em ambiente protegido, sob diferentes níveis de sombreamento, em duas épocas do ano. Horticultura Brasileira, v.18, p.232-233, jul. 1996. Suplemento.

FARIAS, J.R.B. Respostas do feijão-de-vagem à disponibilidade hídrica associada a alterações micrometeorológicas em estufa plástica. Porto Alegre: UFRGS, 1991. 177p.

FARIAS, J.R.B.; BERGAMASCHI, H.; MARTINS, S.R.; BERLATO, M.A.; OLIVEIRA, A.C.B. Alterações na temperatura e umidade relativa do ar provocadas pelo uso de estufa plástica. Revista Brasileira de Agrometeorologia, v.1, n.1, p.51-62, 1992.

FARIAS, J.R.B.; BERGAMASCHI, H.; MARTINS, S.R.; BERLATO,M.A. Efeito da cobertura plástica de estufa sobre a radiação solar. Revista Brasileira de Agrometeorologia, v.1, p.31-36, 1993.

FEUILLOLEY, P.; MEKIKDJIAN, C.; SEVILA, F. Static aeration in greenhouses. Acta Horticulturae, n. 281, p. 175-182, 1990.

FNP CONSULTORIA \& Comércio. Agrianual 2001: Anuário de agricultura brasileira São Paulo, 2001, p. 337-342.

FOLEGATTI, M.V.; SCATOLINI,M.E.; PAZ, V.P.S.; PEREIRA, A.R.; FRIZZONE, J.A. Efeitos da cobertura plástica sobre os elementos meteorológicos e evapotranspiração da cultura do crisântemo em estufa. Revista Brasileira de Agrometeorologia, v.5, n.2, p.155-163, 1997.

FUGIWARA, A. T. Influência da vida útil de coberturas plásticas na luminosidade interna de estufas agrícolas. Ituverava, 2000. 35p. Monografia (Graduação) - Faculdade de Agronomia "Dr. Francisco Maeda". 
FURLAN, R.A. Avaliação da nebulização e abertura de cortinas na redução da temperatura do ar em ambientes protegidos. Piracicaba, 2001. 146p. Tese (Doutorado)- Escola Superior de Agricultura "Luiz de Queiroz", Universidade de São Paulo.

GOTO, R. Plasticultura nos trópicos: uma avaliação técnico-econômica. Horticultura Brasileira, v.15, p.163-165, 1997. Suplemento.

HARDOIN, P.C. Qualidade do ar: sistemas de ventilação natural e artificial na exploração avícola. In: SIMPÓSIO INTERNACIONAL SOBRE AMBIÊNCIA E INSTALAÇÃO NA AVICULTURA INDUSTRIAL, Campinas, SP. Livro de textos. Campinas: FACTA, 1995. p.89-98.

HEAD, O. Our growing is getting better. Journal of the Bromeliad Society, v.47, n.1, p.6-7, 1997.

INSTITUTO BRASILEIRO DE FLORICULTURA. Distribuição da Produção de Flores no Brasil, número de produtores, área cultivada e vendas por região/estado. (www.ibraflor.com.br, 10/Jan/2002)

KAI, E.S.; SILVA.I.J.O. Variações microclimáticas em estufas cobertas com polietileno e PVC. In: SIMPÓSIO DE INICIAÇÃO CIENTÍFICA DA UNIVERSIDADE DE SÃO PAULO, 6., Piracicaba, 1998. Resumos. São Paulo: USP 1999. p.540.

KAI, E.S.; SILVA, I.J.O. da; PIEDADE, S.M. Avaliação do sistema de ventilação natural com o uso de janela zenital no condicionamento térmico de estufas. In: CONGRESSO BRASILEIRO DE OLERICULTURA. 40; CONGRESSO IBERO-AMERICANO SOBRE A UTILIZAÇÃO DE PLÁSTICO NA AGRICULTURA 2.; SIMPÓSIO LATINO-AMERICANO DE PRODUÇÃO DE PLANTAS MEDICINAIS, AROMÁTICAS E CONDIMENTARES, 1., São Pedro, 2000. Anais. Revista da Sociedade de Olericultura do Brasil. v. 18, p. 238-239, jul. 2000. Suplemento

KÄMPF,A.N. (Coord). Produção comercial de plantas ornamentais. Guaíba: Agropecuária, 2000.254p. 
KANASHIRO, S. Efeitos de diferentes substratos na produção da espécie Aechmea fasciata (Lindley) Baker em vasos. Piracicaba, 1999. 79p. Dissertação (Mestrado) - Escola Superior de Agricultura "Luiz de Queiroz", Universidade de São Paulo.

KUMAGAIA, P. Plasticultura na cooperativa agrícola de Cotia - Cooperativa Central. In: SIMPÓSIO NACIONAL SOBRE PLASTICULTURA, 1., Jaboticabal,1989. Anais. Jaboticabal: FUNEP, 1991. p.53-55.

LAMONT JUNIOR, W.J. What are the components of a plasticulturae vegetable system? Horticulturae Technology, v.6, n.3, p.150-154, 1996.

LEME, E.M.C. Bromélias. Ciência Hoje, v.3, n.14, p.66-72, out. 1984.

LORENZI, H.; SOUZA, H.M. de. Plantas ornamentais no Brasil: arbustivas, herbáceas e trepadeiras. Nova Odessa: Plantarum, 2001. 1085p.

MARTINEZ GARCIA, P.F. La regulación de las condiciones del ambiente en los cultivos protegidos. In: FERIA TECNICA INTERNACIONAL DE LA MAQUINARIA AGRICOLA, Zaragoza, 1996. Anais. Zaragoza: Associación de Ingenieros Agronomos, 1986. p.135-147.

MARTINS, S.R. Desafios da plasticultura brasileira: limites sócio-econômicos e tecnológicos frente as novas e crescentes demandas. Horticultura Brasileira, v.14, n.2, p.113-138, nov. 1996.

MARTINS, S.R., GONZALEZ, J.F. Avaliação do resfriamento em estufa plástica mediante sistema de ventilação e nebulização. Revista Brasileira de Agrometeorologia, v.3, p.13-18, 1995.

MARTINS, S.R.; FERNANDES, H.S.; ASSIS, F. N. de; MENDEZ, M.E.G. Caracterização climática e manejo de ambientes protegidos: a experiência brasileira. Informe Agropecuário, v. 20, n. 200/201, p. 15-23, set./dez. 1999.

MATALLANA GONZALES, A. MONTERO CAMACHO, J. I. Invernaderos: Diseño, construcción y ambientación. Madrid: Mundi-Prensa, 1993, 159p.

MATSUNAGA, M. Floricultura como alternativa econômica na agricultura. Informações Econômicas, v. 25, n.11, p. 94-98, nov. 1995. 
MONTERO, J.I.; ANTÓN, A. Greenhouse coolong during warm periods. Acta Horticulturae, n. 357, p. 49-61, 1994.

MONTERO, J.I.; ANTÓN, A.; BIEL, C.; FRANQUET, A. Cooling of greenhouse with compressed air fogging nozzels. Acta Horticulturae, n. 281, p. 199209, 1990.

NASCIMENTO, A. L.C., SILVA, I.J.O. da. Influência de diferentes alturas de estufas nas condições do microclima interno. In: SIMPÓSIO DE INICIAÇÃO CIENTíFICA DA UNIVERSIDADE DE SÃO PAULO, 7., SICUSP/ Agropecuária. Piracicaba, SP, 1999. CD-ROM.

OLIVEIRA, C. R. de. Cultivo em ambiente protegido. Campinas: Coordenadoria de Assistência Técnica Integral, 1997. 31p. (CATI. Boletim Técnico, 232).

PAULA, C.C. Cultivo de bromélias. Viçosa: Aprenda Fácil, 2000. 139p.

PEZZOPANE, J.E.M. O uso de estufa com cobertura plástica e de quebraventos na produção de porta-enxertos de seringueira, na região de Campinas, SP. Piracicaba, 1994. 87p. Dissertação (Mestrado) - Escola Superior de Agricultura "Luiz de Queiroz", Universidade de São Paulo.

PRADOS, N.C. Contribuicion al estudio de los cultivos enarenados en Almeria: necessidades hídricas y extration de los nutrientes del cultivo de tomate de crescimento indeterminado en abrigo de polietileno. Almeria, 1986. 195p. Tese (Doutorado) - Caja rural Provincial.

RAULT,P.A. A tunnel greenhouse adapted to the tropical lowland climate. Acta Horticulturae, n.281, p.95-103, 1990.

REIS, N.V.B. Diferencial entre os parâmetros de temperatura interna e externa de uma estufa modelo teto-em-arco: efeito guarda-chuva. In CONGRESSO BRASILEIRO DE AGROMETEOROLOGIA, 10. , Piracicaba, 1997. Anais. Piracicaba: ESALQ, 1997. p.465-467.

REITZ, R. Bromeliáceas e malária-bromélia endêmica. Itajaí: Herbário Barbosa Rodrigues, 1983. 808p. 
SEEMANN, J. Greenhouse climate. In: Seemann, J. et. al. Agrometeorology. Ney York, Springer-Verlag, p.165-178, 1979.

SENTELHAS, P.C., SANTOS, A.O. Cultivo protegido: aspectos microclimáticos. Revista Brasileira de Horticultura Ornamental, v. 1, n.2, p. 108-115, 1995.

SENTELHAS, P.C.; VILLA NOVA, N. A..; ANGELOCCI, L.R. Efeito de diferentes tipos de cobertura, em mini-estufas, na atenuação da radiação solar e da luminosidade. In: CONGRESSO BRASILEIRO DE AGROMETEOROLOGIA, 10, 1997, Piracicaba, SP. Anais. Piracicaba: ESALQ, 1997. p. 479-481

SENTELHAS, P.C.; PEREIRA, A.R.; ANGELOCCI, L.R. Meteorologia Agrícola, Departamento de Física e Meteorologia - Escola Superior de Agricultura "Luiz de Queiroz" - Universidade de São Paulo, Piracicaba, 1998. 131p. (Apostila)

SGANZERLA, E. Nova agricultura: a fascinante arte de cultivar com os plásticos. 5.ed. Guaíba: Agropecuária, 1995. 342p.

SILVA, R.G. Introdução à bioclimatologia. São Paulo: Nobel, 2000.

SLATER, L.E. Conocimiento del clima y el problema alimentário mundial. In: SIMPÓSIO INTERAMERICANO SOBRE MODELOS Y SISTEMAS DE INFORMACIÓN AGROCLIMÁTICOS, 1. Caracas, 1983. Anais. Caracas: IAP;BID, 1983. p.59-86.

TANAKA, M.; GENTA, $H$. Control del medio ambiente bajo invernadero y tunel plástico. Salto: Uruguay: Estación Experimental de Citricultura, 1982. $61 \mathrm{p}$.

TROTMAN, L. On bromeliad growing. Journal of the Bromeliad Society, v.40, n.3, p.124-126, 1990.

VECCHIA, P.T.D.;KOCH, P.S. História e perspectivas da produção de hortaliças em ambiente protegido no Brasil. Informe Agropecuário, v.20, n.200/201, p.5-10, set./dez. 1999. 
VITARI, M. Bromélia: produção e proteção. Ecologia e Desenvolvimento, v.3, n. 37, p. 15-17, mar. 1994.

WILLIANS, B; HODGSON. Growing bromeliads. London: Christopher Helm, 1990. 150p. 